\title{
Niches for the Long-Term Maintenance of Tissue-Resident Memory T Cells
}

\author{
Shiki Takamura* \\ Department of Immunology, Faculty of Medicine, Kindai University, Osaka, Japan
}

Tissue-resident memory T cells ( $T_{\mathrm{RM}}$ cells) are a population of immune cells that reside in the lymphoid and non-lymphoid organs without recirculation through the blood. These important cells occupy and utilize unique anatomical and physiological niches that are distinct from those for other memory $T$ cell populations, such as central memory $T$ cells in the secondary lymphoid organs and effector memory $T$ cells that circulate through the tissues. $\mathrm{CD}^{+} \mathrm{T}_{\mathrm{RM}}$ cells typically localize in the epithelial layers of barrier tissues where they are optimally positioned to act as sentinels to trigger antigen-specific protection against reinfection. $\mathrm{CD}^{+} \mathrm{T}_{\mathrm{RM}}$ cells typically localize below the epithelial layers, such as below the basement membrane, and cluster in lymphoid structures designed to optimize interactions with antigen-presenting cells upon reinfection. A key feature of $\mathrm{T}_{\mathrm{RM}}$ populations is their ability to be maintained in barrier tissues for prolonged periods of time. For example, skin CD8 ${ }^{+} \mathrm{T}_{\mathrm{RM}}$ cells displace epidermal niches originally occupied by $\gamma \delta T$ cells, thereby enabling their stable persistence for years. It is also clear that the long-term maintenance of $\mathrm{T}_{\mathrm{RM}}$ cells in different microenvironments is dependent on multiple tissue-specific survival cues, although the specific details are poorly understood. However, not all $T_{\mathrm{RM}}$ persist over the long term. Recently, we identified a new spatial niche for the maintenance of $C D 8^{+} T_{R M}$ cells in the lung, which is created at the site of tissue regeneration after injury [termed repair-associated memory depots (RAMD)]. The short-lived nature of RAMD potentially explains the short lifespans of CD8 ${ }^{+} T_{R M}$ cells in this particular tissue. Clearly, a better understanding of the niche-dependent maintenance of $T_{\mathrm{RM}}$ cells will be important for the development of vaccines designed to promote barrier immunity. In this review, we discuss recent advances in our understanding of the properties and nature of tissue-specific niches that maintain $\mathrm{T}_{\mathrm{RM}}$ cells in different tissues.

Keywords: distribution of memory T cells, maintenance of memory T cells, mucosal immunity, infectious immunity, vaccine

\section{INTRODUCTION}

When naïve $\mathrm{T}$ cells encounter cognate antigen in the draining lymph node (LN), the cells are activated, initiate a proliferative program, and differentiate into a heterogeneous population of effector $\mathrm{T}$ cells. These effector $\mathrm{T}$ cells then home back to the site of infection and eliminate pathogen-infected cells. While most effector cells die after clearance of the pathogens, some cells subsequently differentiate into memory $\mathrm{T}$ cells. During the course of a $\mathrm{T}$ cell response, each $\mathrm{T}$ cell 
receives spatially and temporally distinct instructive signals that impact their ultimate fate; either death or differentiation into different types of memory cells with distinct functional and migratory properties $(1,2)$. For example, $T$ cells primed by antigen-presenting cells (APC) with weak stimulatory potential preferentially remain in the $\mathrm{LN}$ and differentiate into central memory $\mathrm{T}$ cells $\left(\mathrm{T}_{\mathrm{CM}}\right.$ cells) where they survey lymph and blood $(3,4)$. On the other hand, T cells primed by APC with high stimulatory potential (e.g., strong costimulation) differentiate into potent effector cells that migrate to inflamed tissues and subsequently die (3). Effector cells that additionally receive tissue-specific instructive signaling differentiate into tissueresident memory $\mathrm{T}$ cells ( $\mathrm{T}_{\mathrm{RM}}$ cells) and establish permanent residency within the tissues $(1,5)$. Effector $\mathrm{T}$ cells that fail to receive optimal tissue-instructive signals may differentiate into effector memory $\mathrm{T}$ cells ( $\mathrm{T}_{\mathrm{EM}}$ cells) that circulate between blood and certain peripheral tissues.

It is now appreciated that $\mathrm{T}_{\mathrm{RM}}$ cells comprise the majority of memory $\mathrm{T}$ cells in the non-lymphoid tissues (NLT) and confer immediate protection against infection of barrier tissues (6). These cells are part of a comprehensive memory response that also include the $\mathrm{T}_{\mathrm{CM}}$ and $\mathrm{T}_{\mathrm{EM}}$ populations. $\mathrm{T}_{\mathrm{CM}}$ cells exhibit high proliferative potential upon reactivation in the $\mathrm{LN}$, thereby providing a major source of secondary effector cells that ultimately facilitate pathogen clearance (7). $\mathrm{T}_{\mathrm{EM}}$ cells play a supportive role to $\mathrm{T}_{\mathrm{RM}}$ by virtue of their immediate effector functions and their ability to rapidly traffic sites of infection (8). While the maintenance of circulatory memory $\mathrm{T}$ cell populations $\left(\mathrm{T}_{\mathrm{CM}}\right.$ and $\mathrm{T}_{\mathrm{EM}}$ ) has been shown to depend on the homeostatic cytokines IL-7 and IL-15, the factors that regulate the maintenance of $T_{R M}$ cells are ill defined. Furthermore, since $\mathrm{T}_{\mathrm{RM}}$ cells in each tissue are maintained in distinct microenvironments, these cells must adapt to local cues for their long-term survival.

The external or internal surfaces of the body such as the skin and the mucosal linings of the gastrointestinal, respiratory, and urogenital tracts are a major gateway for infectious pathogens to access to the body. The surfaces of these barrier tissues are covered by different types of epithelial layers: from single layers of flattened or columnar cells to multiple layers of different types of epithelial cells. Each of these epithelial layers, along with the connective tissues that underlie the epithelium in each tissue, provide distinct microenvironments depending on their particular physiological and functional needs. The different types of immune cells that reside in these distinct microenvironments, such as macrophages, dendritic cells (DC), $\gamma \delta$ T cells, and innate lymphoid cells (ILC), each adapt to these unique environments and play important roles in maintaining the integrity of these epithelial barriers (9-12). Accumulating evidence has revealed that the relationship between $\mathrm{T}_{\mathrm{RM}}$ cells in these tissues and the original resident cell populations is dynamic and complex. For example, some tissue-resident immune cells interact with $\mathrm{T}_{\mathrm{RM}}$ cells and provide niche factors for their maintenance (13-15). In other cases, tissue-resident immune cells and $\mathrm{T}_{\mathrm{RM}}$ cells share local signals necessary for their long-term survival or compete with one another for access to niches that enable them to persist in the tissue (16). Furthermore, it is becoming clear that $\mathrm{T}_{\mathrm{RM}}$ cells are also established in non-barrier tissues (such as the brain, liver, and kidney) as well as the primary lymphoid organs and secondary lymphoid organs (SLOs) and protect tissues from infectious pathogens disseminated by hematogenous or cellular (e.g., neural) pathways (17). The niches and factors that enable the maintenance of $\mathrm{T}_{\mathrm{RM}}$ cells in these tissues differ significantly from those in the epithelial tissues. In this review, we discuss the distribution of $\mathrm{T}_{\mathrm{RM}}$ cells in each tissue and the factors that influence the establishment and maintenance of $\mathrm{T}_{\mathrm{RM}}$ cells.

\section{NON-LYMPHOID ORGANS}

\section{Barrier Tissues \\ Skin}

The skin is comprised of three main layers: the epidermis, dermis, and subcutaneous fatty region. The epidermis and dermis are separated by a basement membrane and harbor numerous unique populations of innate and adaptive immune cells. Many of these cells are resident populations and form a sophisticated immune network that provides a biological barrier against invading pathogens (18).

The epidermis is an avascular tissue composed primarily of keratinocytes (19). Dead keratinocytes comprise the outmost layer of the epidermis, known as the stratum corneum, and serve as a physiological barrier (20). Keratinocytes in the deeper layers, such as the stratum granulosum and stratum spinosum, provide integrity to the skin and play multiple roles in the initiation of local immunity by recognizing pathogens through pattern recognition receptors and by secreting a wide variety of cytokines and chemokines (21). These cells also secrete various factors necessary for the development and homeostasis of immune cells residing in the epidermis (21). The bottom layer, the stratum basale, consists primarily of a single layer of basal cells-precursors of the keratinocytes that comprise the upper layers of the skin (22). The hair follicles also consist of keratinocytes and provide unique niches for immune cells including $\mathrm{T}_{\mathrm{RM}}$ cells (23).

At least three immune cell types are maintained in the epidermis: Langerhans cells (LC), dendritic epidermal T cells (DETC) expressing $\gamma \delta$ T cell receptors (TCR), and memory T cells expressing $\alpha \beta$ TCR. These cells do not recirculate under steady-state conditions, exhibit a dendritic morphology, and inhabit several anatomical as well as physiological niches for their development and maintenance (20).

Langerhans cells are present in all layers of the epidermis, especially in the stratum spinosum, and are the only APC in the epidermis under steady-state conditions (24). The development and maturation of LC depends on transforming growth factor- $\beta$ (TGF- $\beta$ ), which is secreted by keratinocytes, DETC (paracrine), and the LC themselves (autocrine) (24). Although TGF- $\beta 1$ is secreted as a latent (inactive) form, it is trans-activated by integrin $\alpha_{v} \beta_{6}$ and $\alpha_{v} \beta_{8}$ expressed on keratinocytes in the interfollicular regions and near the hair follicles $(25,26)$. TGF- $\beta$ has also been shown to be required for the retention of LC within the epidermis since the loss of TGF- $\beta 1$ signaling leads to the spontaneous migration of LC to the regional LN (25). In addition to initiating adaptive immune responses, $\mathrm{LC}$ are also involved in the induction 
of tolerance by promoting the proliferation of regulatory $\mathrm{T}$ (Treg) cells in the epidermis under steady-state conditions (27).

In mice, DETC comprise a large proportion of immune cells in the epidermis (20). DETC are distributed throughout the epidermis, secrete a variety of cytokines, chemokines, and growth factors, and play key roles in the wound repair, tumor surveillance, and inflammation (28). They persist in the epidermis for life and are maintained by homeostatic turnover. Common $\gamma$-chain signaling through IL-7 and IL-15, as well as signaling via the aryl hydrocarbon receptor (AhR) are known to be required for the development and maintenance of DETC (29-32). This is consistent with the fact that AhR ligands are abundant in the skin since they are formed from tryptophan via ultraviolet radiation (33). In contrast to LC, the maintenance of DETC is independent of TGF- $\beta$ (34).

The majority of $\alpha \beta \mathrm{T}$ cells that reside in the epidermis are $\mathrm{CD}^{+} \mathrm{T}_{\mathrm{RM}}$ cells (35) (Figure 1). These cells express canonical $\mathrm{T}_{\mathrm{RM}}$ makers such as the activation marker CD69, the E-cadherinbinding integrin $\mathrm{CD} 103$, and the collagen-binding integrin CD49a, in the absence of cognate antigen signaling $(36,37)$. Although $\mathrm{CD}^{+} \mathrm{T}_{\mathrm{RM}}$ cells are widely found throughout the body (38), their numbers are generally elevated at sites of infection and/or inflammation $(37,39,40)$. Several chemokines are known to be involved in the recruitment of $\mathrm{CD}^{+} \mathrm{T}_{\mathrm{RM}}$ precursors $\left(K L R G 1^{10}\right)$ into the epidermis, including cutaneous T cell-attracting chemokine (CTACK), CXCL9 and CXCL10. CTACK is constitutively expressed by epidermal keratinocytes and attracts CCR10 expressing T cells (41). Since memory $\mathrm{T}$ cells do not express CCR10, it is likely that CTACK primarily drives the recruitment of effector $\mathrm{T}$ cells to the epidermis, but not the retention of memory $\mathrm{T}$ cells at that site (42). Other inflammatory chemokines, such as CXCL9 and CXCL10, are highly expressed by keratinocytes in response to infection, and facilitate the recruitment of $\mathrm{CXCR}^{+}$memory precursor effector CD8 ${ }^{+} \mathrm{T}$ cells to the epidermis (43). Like LC, these cells subsequently receive TGF- $\beta$ signals upon arrival, which is a critical factor for the upregulation of the E-cadherin binding integrin, CD103 (43) (Figure 1). Since E-cadherin is expressed on epithelial cells, including keratinocytes, it is likely that the upregulation of CD103 facilitates the retention of T cells in the epidermis (44). TGF- $\beta$ signaling also downregulates the T-box family protein T-bet and eomesodermin, a process of which facilitates $\mathrm{T}_{\mathrm{RM}}$ cell development (45). CCR8 expression is also upregulated following the migration of $\mathrm{T}$ cells into the epidermis by yet unidentified factors derived from keratinocytes. It appears likely that this chemokine receptor also facilitates the maintenance of cells within the epidermis $(46,47)$. Finally, there may also be a role for CXCR6 in the maintenance of $\mathrm{T}_{\mathrm{RM}}$

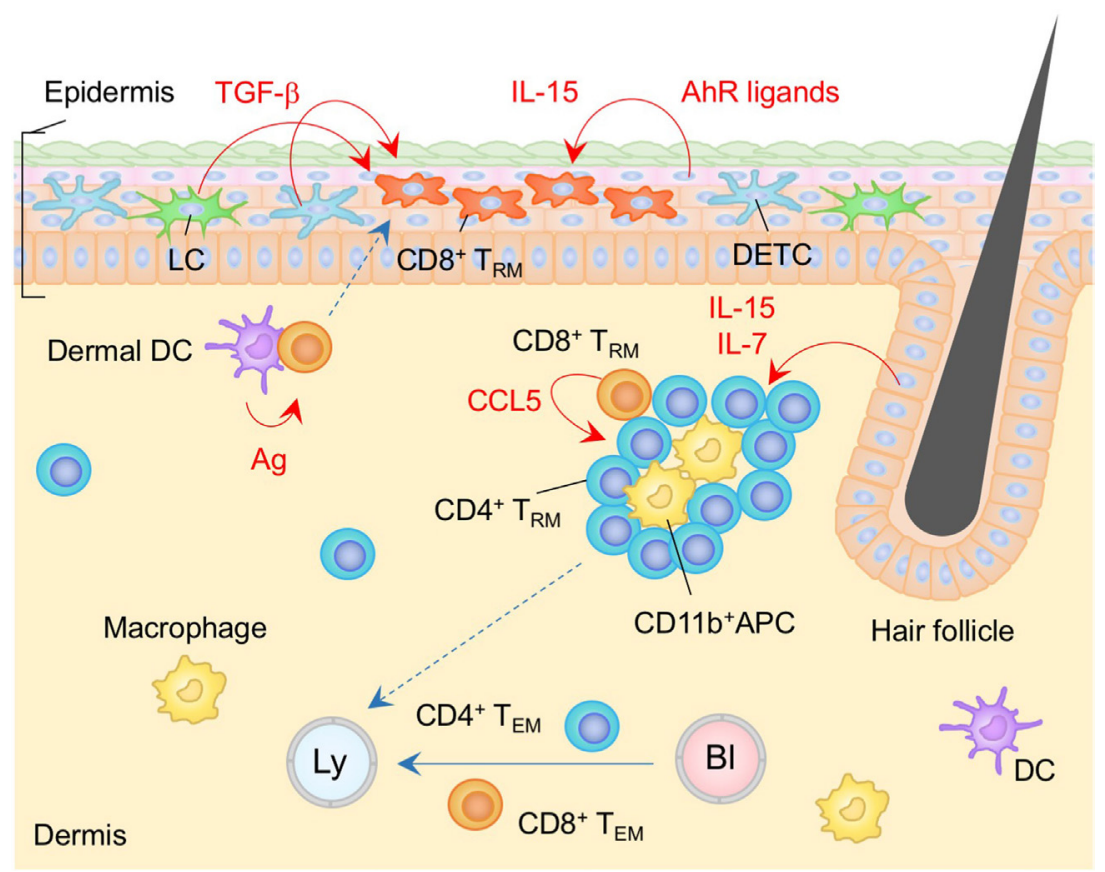

FIGURE $1 \mid T_{\mathrm{RM}}$ niches in the skin. Langerhans cells (LC), dendritic epidermal $\mathrm{T}$ cells (DETC) expressing $\gamma \delta \mathrm{T}$ cell receptors, and CD8 ${ }^{+} \mathrm{T}_{\mathrm{RM}}$ cells are maintained in the epidermis. CD8 ${ }^{+} \mathrm{T}_{\mathrm{RM}}$ cells displace epidermal niches originally occupied by DETC at the site of infection. Transforming growth factor (TGF)- $\beta$ secreted from LC and DETC, IL-15, and aryl hydrocarbon receptor (AhR) ligands play a role in the generation and maintenance of epidermal CD8 ${ }^{+} \mathrm{T}_{\mathrm{RM}}$ Cells. Memory $\mathrm{CD} 4^{+} \mathrm{T}_{\mathrm{C}}$ cells in the dermis form clusters with CD11 b+ APC around the hair follicles. CCL5 secreted from peri-collicular CD8 ${ }^{+} \mathrm{T}$ cells promotes formation of clusters. Although most memory $\mathrm{CD}^{+}{ }^{+} \mathrm{T}$ cells in the cluster exhibit canonical $\mathrm{T}_{\mathrm{RM}}$ phenotypes, long-period parabiosis experiments revealed that this population is slowly replenished by cells from the circulation. IL-7 and IL-15 secreted from keratinocytes in the hair follicles promote T cell persistence in the cluster. $T_{E M}$ cells are passing through the dermis. Orange and blue cells indicate $\mathrm{CD}^{+}$and $\mathrm{CD}^{+}{ }^{+} \mathrm{T}_{\mathrm{RM}}$ cells, respectively, unless otherwise stated. Red lines indicate the representative niche factors that influence the maintenance of $\mathrm{T}_{\mathrm{RM}}$ cells. Blue lines indicate the migratory routes. Dashed lines indicate potential impact of niche factors (red) or migratory routes (blue). Abbreviations: Ly, lymph vessel; BI, blood vessel; Ag, antigen; APC, antigen-presenting cell; $\mathrm{T}_{\mathrm{RM}}$, tissue-resident memory T cells; $\mathrm{T}_{\mathrm{EM}}$, effector memory T cells. 
in the epidermis since its absence results in a marked reduction in the number of skin CD8 ${ }^{+} \mathrm{T}_{\mathrm{RM}}(42)$.

$\mathrm{CD}^{+} \mathrm{T}_{\mathrm{RM}}$ cells in the epidermis display a unique dendritic morphology $(16,35,48)$, which is distinct from that of LC and DETC $(20,48)$. Epidermal CD8 ${ }^{+} \mathrm{T}_{\mathrm{RM}}$ cells are located in the basal layers of the epidermis and slowly but continuously migrate between keratinocytes, while LC and DETC are mostly immotile $(16,48)$. Importantly, Zaid et al. have demonstrated a substantial decrease in the numbers of DETC and a concomitant increase in the numbers of $\mathrm{CD}^{+} \mathrm{T}_{\mathrm{RM}}$ cells at the site of infection, indicating the strict competition between DETC and CD8 ${ }^{+} \mathrm{T}_{\mathrm{RM}}$ cells for the epidermal niches (16) (Figure 1). Furthermore, both of these populations also depend on locally produced homeostatic signals, such as IL-15 and AhR ligands, for their long-term maintenance $(16,30,32,43)$. These common features may explain the stable persistence of $\mathrm{CD}^{+} \mathrm{T}_{\mathrm{RM}}$ cells within the epidermal niches for many years without repopulation by DETC (16). Furthermore, the relatively higher numbers of $\alpha \beta$ T cells, as compared to $\gamma \delta$ T cells, in the human epidermis might be a consequence of the persistent occupation of epidermal niches by $C D 8^{+} \mathrm{T}_{\mathrm{RM}}$ cells generated by prior infection and/or inflammation (20). It is important to note here that the capacity of epidermal $\mathrm{T}_{\mathrm{RM}}$ niches are extremely large (approximately $7 \times 10^{3}$ $\mathrm{T}$ cells $/ \mathrm{cm}^{2}$ ) (49). The high capacity of epidermal niches allows the de novo establishment of $\mathrm{T}_{\mathrm{RM}}$ cells with different specificities without displacement of pre-existing $\mathrm{T}_{\mathrm{RM}}$ cells after rechallenge. Importantly, this allows $\mathrm{T}_{\mathrm{RM}}$ cells with multiple specificities to be stably maintained in the epidermis (49). By contrast, $\gamma \delta$ $\mathrm{T}$ cells are displaced by $\mathrm{CD} 8^{+} \mathrm{T}_{\mathrm{RM}}$ cells even when the number of $\mathrm{T}_{\mathrm{RM}}$ cells relatively low, suggesting an occupational advantage for $\mathrm{CD}^{+} \mathrm{T}_{\mathrm{RM}}$ cells over $\gamma \delta \mathrm{T}$ cells in the epidermal niches. Finally, since the environment in which epidermal $\mathrm{CD}^{+} \mathrm{T}_{\mathrm{RM}}$ cells persist has limited access to blood-derived signals as well as nutrients, these cells uniquely express fatty acid transporters, Fabp4 and Fabp5, and rely on extracellular fatty acid for their survival (50).

The dermis that underlies the basement membrane is composed mainly of fibroblasts and the extracellular matrix (a network of collagen and elastin fibers). Heterogeneous populations of immune cells, including $\alpha \beta$ T cells, $\gamma \delta$ T cells, subsets of DC, macrophages, mast cells, and ILC are all found in the dermis (21). The dermis also contains both lymphatic and blood vessels, providing a source of $\mathrm{T}_{\mathrm{EM}}$ cells that are transiting through the tissues.

In contrast to the situation in the epidermis, most $\alpha \beta \mathrm{T}$ cells located in the dermis are CD $4^{+} \mathrm{T}$ cells, including both conventional $\mathrm{T}$ cells and Treg $(14,35,51,52)$. These cells display an amoeboid morphology and traffic rapidly through the dermis (35). Long-period parabiosis experiments (12-16 weeks) using naive animals has revealed that a large fraction of $\mathrm{CD} 4^{+} \mathrm{T}$ cells recruited from the circulation acquire the expression of CD69 and CD103 following entry into the skin (14). Of note, $\mathrm{T}_{\mathrm{RM}^{-}}$ phenotype $\mathrm{CD} 4^{+} \mathrm{T}$ cells in the dermis are tissue-circulating $\mathrm{T}_{\mathrm{EM}}$ cells despite their relatively slow turnover rate, as the ratio of host and partner $\mathrm{CD} 4^{+} \mathrm{T}$ cells was equilibrated in these parabiosis experiments (14). These $\mathrm{CD}^{+} \mathrm{T}$ cells form clusters with $\mathrm{CD}_{1} 1 \mathrm{~b}^{+} \mathrm{APC}$ around hair follicles (14) (Figure 1). The numbers of hair follicle-associated clusters, as well as the numbers of
$\mathrm{CD}^{+} \mathrm{T}$ cells within each cluster, are increased following local infection and/or inflammation, indicating that tissue conditioning creates new dermal CD4 ${ }^{+} \mathrm{T}$ cell niches (14). CCL5 secreted from peri-follicular $\mathrm{CD}^{+} \mathrm{T}$ cells promotes the formation of the $\mathrm{CD}^{+} \mathrm{T}$ cell clusters (14). In addition, IL-7 and IL-15 are predominantly secreted by unique population of keratinocytes in the hair follicles, helping to sustain $\mathrm{T}$ cell persistence within the cluster (23). Such unique structures are potentially identical to the classical inducible skin-associated lymphoid tissues that provide both spatial and physiological niches for the maintenance of memory T cells (53).

Although local tissue instructions promote the formation of $\mathrm{T}_{\mathrm{RM}}$ in the absence of local antigen (37), recent studies have revealed that encounters with cognate antigen at the site of infection significantly enhance the establishment of $\mathrm{CD} 8^{+}$ $\mathrm{T}_{\mathrm{RM}}$ cells in the skin, presumably in the epidermis (54). While several cell-intrinsic mechanisms of $\mathrm{T}_{\mathrm{RM}}$ formation induced by an antigen-driven "second hit" are suggested (5), one certain outcome is the upregulation of CD69 (54). It has been established that $\mathrm{T}$ cells recruited to peripheral tissues upregulate sphingoshin-1-phosphate receptor $1\left(\mathrm{~S}_{1} \mathrm{P}_{1}\right)$, and sense the gradient of sphingoshin-1-phosphate (S1P) (55), which guides $\mathrm{T}$ cells to the draining lymphatics of the tissue. Surface expression of CD69 antagonizes the expression of $\mathrm{S}_{1} \mathrm{P}_{1}(56)$, thereby inhibiting the egress of T cells from the skin (57). Since lymphatic vessels are not found in the epidermis, it is likely that the second antigen hit and the resultant retention induced by CD69-mediated inhibition of $\mathrm{S}_{1} \mathrm{P}_{1}$ occurs in the dermis, and subsequently promotes the establishment of $\mathrm{CD}^{+} \mathrm{T}_{\mathrm{RM}}$ in the epidermis. In support of this concept, APC in the skin function as a gatekeeper for the development of $\mathrm{CD}^{+} \mathrm{T}_{\mathrm{RM}}$ cells, such that $\mathrm{CD}^{+} \mathrm{T}$ cells with distinct antigen specificities compete for APC as a source of second hit signaling, leading to the selection of dominant epitope-specific $\mathrm{CD}^{+}{ }^{+} \mathrm{T}$ cells (58). This leads to the reduced formation of $\mathrm{CD}^{+} \mathrm{T}_{\mathrm{RM}}$ cells specific for subdominant epitopes since these $\mathrm{T}$ cells presumably fail to receive second antigen hit signaling and rapidly egress from the dermis. Such antigenic selection may be the underlying mechanism driving the accumulation of highly functional, melanocyte antigenspecific $\mathrm{CD}^{+} \mathrm{T}_{\mathrm{RM}}$ cells in the vitiligo-affected skin $(59,60)$. It is important to note that transcriptional downregulation of Klf2, as well as its downstream target S1pr1 (which encodes $\mathrm{S}_{1} \mathrm{P}_{1}$ ), is also induced by several cytokines such as TGF- $\beta$, IL-33, and tumor necrosis factor (TNF), even in the absence of local antigen (61). However, certain factors that enable the acquisition of a unique transcription profile defining $\mathrm{T}_{\mathrm{RM}}$ cells, including the upregulation of Hobit and Blimp1, have not been not fully elucidated $(62,63)$.

\section{Gut, Intestine}

The intestinal mucosa consists of a single layer of intestinal epithelial cells that overlies the lamina propria (LP), a thin layer of loose connective tissue. The epithelium and LP are separated by a basement membrane and each provides a distinct immunological niche for the maintenance of $\mathrm{T}_{\mathrm{RM}}$ cells.

The diverse populations of immune cells embedded within the intestinal epithelium are referred to as intestinal intraepithelial 
lymphocytes (IELs). The greatest concentration of IEL is located in the small intestine (SI) where there are approximately 10-15 IEL per 100 epithelial cells. This ratio of IEL to epithelial cells gradually decreases along the intestines, such that the colon hosts relatively few IEL (64). The differences in the relative numbers of IEL in each intestinal compartment likely reflects regional differences in the anatomy of the villi, the intestinal microenvironment (including microbiota), and the composition of epithelial cells (e.g., enterocytes, goblet cells, Paneth cells, enteroendocrine cells, and stem cells). Epithelial cells are a dynamic population and cells situated at the top of the villi typically die within 3-5 days and are continually replaced by new cells generated from the progenitor cells located in the crypt. Despite the short lifespan of epithelial cells, IEL are resident and do not recirculate (65).

Intraepithelial lymphocytes in the intestines are primarily $\mathrm{T}$ cells, although there is also a small population of cells that are negative for TCR, such as ILC-like cells (66). IEL T cells can be divided into two subsets, referred to as peripheral and thymic. Peripheral IEL (type a, induced or conventional) are derived from antigen-experienced $\mathrm{CD}^{+}$or $\mathrm{CD}^{+} \mathrm{T}$ cells that have homed to the epithelium. Thymic IEL (type b, natural or unconventional) express CD $8 \alpha$ homodimers with either TCR $\alpha \beta$ or TCR $\gamma \delta$, and migrate from the thymus to the epithelium shortly after birth (67). In mice, thymic IEL dominate in the SI while peripheral IEL dominate in the colon (64). The overall ratio of thymic to peripheral IEL declines with age, although the total number of IEL remains relatively constant $(67,68)$, suggesting that the two types of IEL share the same spatial niche in the epithelium. However, there is a severe reduction in the numbers of peripheral but not thymic IEL in germ-free animals (69), suggesting that the physiological niches that maintain peripheral and thymic IEL must differ in some way. This review will focus on peripheral IEL.

Significant numbers of antigen-specific $\mathrm{T}_{\mathrm{RM}}$ cells are established in the intraepithelial compartment following intestinal infections (70-72) (Figure 2). The majority of these cells are $\mathrm{CD}^{+} \mathrm{T}$ cells,

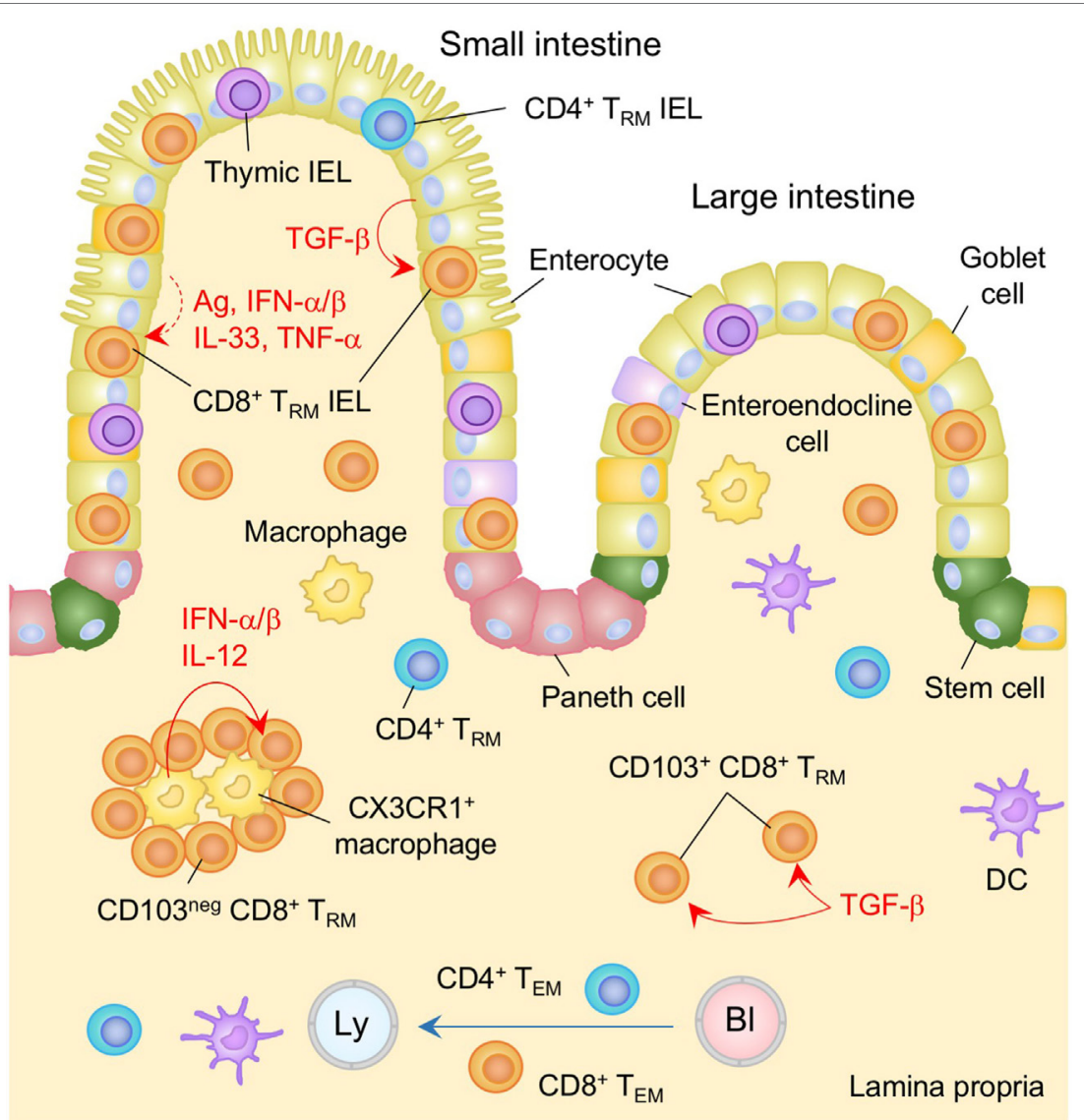

FIGURE $2 \mid T_{R M}$ niches in the in the intestine. Large numbers of CD8 ${ }^{+} T_{R M}$ cells and few numbers of CD4 ${ }^{+} T_{R M}$ cells are present in the intestinal intraepithelial lymphocyte (IEL) compartment. TGF- $\beta$ is constitutively available in the intestinal epithelium and promotes the generation of $\mathrm{T}_{\mathrm{RM}}$ cells in this compartment by upregulating CD103 as well as Runx3. Either cognate antigen or inflammatory cytokines is required for upregulation of CD69 on epithelial $T_{\mathrm{RM}}$ cells. Both TGF- $\beta$-dependent $\left(\mathrm{CD}_{103^{+}}\right)$and independent (CD103-) populations of $\mathrm{CD} 8^{+} \mathrm{T}_{\mathrm{RM}}$ cells present in the lamina propria (LP). The latter form cluster with $\mathrm{CX} 3 \mathrm{CR} 1^{+}$ macrophages. Interferon (IFN)- $\alpha / \beta$ and IL-12 secreted by macrophages control the size of the cluster. TEM cells are passing through the LP. Orange and blue cells indicate $\mathrm{CD}^{+}$and $\mathrm{CD} 4^{+} \mathrm{T}_{\mathrm{RM}}$ cells, respectively, unless otherwise stated. Red lines indicate the representative niche factors that influence the maintenance of $\mathrm{T}_{\mathrm{RM}}$ cells. A blue line indicates the migratory route. A dashed line indicates potential impact of niche factors. Abbreviations: Ly, lymph vessel; BI, blood vessel; Ag, antigen; neg, negative; $\mathrm{T}_{\mathrm{RM}}$, tissue-resident memory $\mathrm{T}$ cells; $\mathrm{T}_{\mathrm{EM}}$, effector memory $\mathrm{T}$ cells. 
although smaller numbers of $\mathrm{CD} 4^{+} \mathrm{T}$ cells are also observed (73). Interestingly, a large number of memory-like $\gamma \delta \mathrm{T}$ cells is also generated following intestinal infection. However, these cells are rarely found in the IEL compartment, suggesting that $C D 8^{+} T_{R M}$ cells but not $\gamma \delta \mathrm{T}$ cells are preferentially lodged in the intraepithelial niches (74). Nearly all $\mathrm{CD}^{+} \mathrm{T}_{\mathrm{RM}}$ cells in this compartment express CD69 and CD103 $(70,71)$ and are scattered within the epithelium. Recruitment of effector cells to this site, including $\mathrm{T}_{\mathrm{RM}}$ precursors, is governed by the $\alpha 4 \beta 7$ and CCR9 integrins, both of which are upregulated on $\mathrm{T}$ cells, mainly in response to retinoic acid (a vitamin A metabolite) which is present during priming in the intestinal inductive sites (75). The $\alpha 4 \beta 7$ integrin facilitates the extravasation of the cells from the venules in the LP $(76,77)$. CCR9 is required for T cell migration to the SI $(78,79)$, since its ligand, CCL25, is constitutively expressed by epithelial cells in the SI but not the colon (80).

As with thymic IEL, a process of tissue adaptation takes place following recruitment of peripheral $\mathrm{CD} 8^{+} \mathrm{T}$ cells into the epithelium. Specifically, the local environment promotes the differentiation of effector $\mathrm{T}$ cells into $\mathrm{T}_{\mathrm{RM}}$ and facilitates their subsequent retention at that site. In this regard, TGF- $\beta$, which is constitutively available at the intestinal epithelium $(81,82)$ (Figure 2), induces the upregulation of $\mathrm{CD} 103$ on recent immigrants. Consistent with this, the lack of CD103 or the TGF- $\beta$ receptor on $\mathrm{T}$ cells is correlated with a significant defect in the accumulation of both peripheral and thymic IEL within the intestinal epithelium (71, 83-85). By contrast, overexpression of TGF- $\beta$ results in increased proportion of thymic IEL in the SI (86), highlighting the non-redundant, regulatory role of TGF- $\beta$ in the number of $\mathrm{T}_{\mathrm{RM}}$ cells retained in the intestinal epithelium. TGF- $\beta$ signaling also induces the expression of Runx3 (87-89), which has been identified as a master regulator of tissue residency (90). Although the precise role of Runx3 in retaining cells in the SI is not yet clear, it is known to promote the expression of CD8 $\alpha \alpha$ (88), which binds to the thymus leukemia antigen that is constitutively expressed on the intestinal epithelium (91). Interestingly, TGF- $\beta$-independent populations of $\mathrm{T}_{\mathrm{RM}}$ cells also accumulate in the IEL compartment during chronic infection with lymphocytic choriomeningitis virus (LCMV) (85). These cells do not express CD103 and are thought to represent recent arrivals that are recruited continually from the circulation upon activation with persistent viral antigens (85).

While $\mathrm{CD} 8^{+} \mathrm{T}_{\mathrm{RM}}$ IEL are associated with gut infection, they are also established following systemic infections $(6,83,85,90$, $92,93)$, and their numbers are especially robust under lymphopenic conditions (e.g., $\left.\mathrm{Rag}^{-/-}\right)(83,93,94)$. IEL generated through systemic immune responses exhibit canonical $\mathrm{T}_{\mathrm{RM}}$ phenotypes $\left(\mathrm{CD} 9^{+} \mathrm{CD}_{103}{ }^{+}\right)$despite the absence of TCR signaling (as determined by the lack of Nur77 expression) (83), indicating that cognate antigen is not required for the upregulation of CD69 in the gut. In fact, some cytokines that can be secreted in the epithelium, such as IL-33, interferon- $\alpha / \beta($ IFN- $\alpha / \beta)$, and TNF- $\alpha$, are known to contribute to the antigen-independent upregulation of CD69 (83). Nevertheless, the number of $\mathrm{CD} 8^{+} \mathrm{T}_{\mathrm{RM}}$ cells established in the intestinal epithelium following systemic priming is significantly less than that generated by gut infection (71). This is largely due to the relatively poor accumulation of memory precursor cells into the intestinal epithelium following non-intestinal infection (71). While significant progress has been made in understanding gut $\mathrm{T}$ cell memory, the impact of infection-driven tissue conditioning on the spatial as well as the physiological niches (local antigen and cytokine milieu) on the maintenance of $T_{R M}$ cells in the intestinal epithelium is largely unknown.

The homeostatic cytokine IL-15 is constitutively produced by intestinal epithelial cells in response to signaling through MyD88, suggesting that there is a background level of stimulation by intestinal microflora (95). As with DETC in the skin epidermis, the development and maintenance of thymic IEL depends on local signaling via IL-15, as lack of this signaling results in the loss of more than $90 \%$ of thymic IEL (96-98). Although it has been proposed that IL-15 produced by inflamed mucosal tissues accelerates the accumulation of circulating effector $\mathrm{CD}^{+} \mathrm{T}$ cells in the SI through the upregulation of the mammalian target of rapamycin and T-bet (93), survival of $\mathrm{CD} 8^{+} \mathrm{T}_{\mathrm{RM}}$ cells in most peripheral tissues, including the SI (both in the epithelial compartment and LP), is independent of IL-15 (99). This suggests that the physiological niches inhabited by peripheral and thymic IEL exhibit different characteristics.

The LP harbors the vast majority of immune cells in the body. These cells are located in organized lymphoid structures, termed gut-associated lymphoid tissues, such as Peyer's patches (PP), cecal patches, colonic patches, cryptopatches, and solitary isolated lymphoid tissues (100). Large numbers of $\mathrm{T}$ cells are present throughout the LP. T-cell homing to small intestinal LP is mediated by integrin $\alpha 4 \beta 7$ and CCR9, whereas the orphan G-proteincoupled receptor 15 is required for migration of $\mathrm{T}$ cells to the large intestinal LP (101). Once in the relevant gut site, $\mathrm{T}$ cells receive instructive signals for their full differentiation into $T_{R M}$ cells. Note that a stable population of memory-like $\gamma \delta \mathrm{T}$ cells is established in the LP, suggesting limited competition of anatomical niches between $\mathrm{T}_{\mathrm{RM}}$ cells and $\gamma \delta \mathrm{T}$ cells in this compartment (74).

In contrast to memory $\mathrm{T}$ cells in the IEL compartment, memory cells located in the LP include both $T_{E M}$ and $T_{R M}$ (Figure 2). This is because the LP contains both lymphatic drainage and blood supplies (65) and suggests that $\mathrm{T}_{\mathrm{RM}}$ cells in this tissue need to continually resist tissue egress signals for their long-term maintenance. CD69 is expressed on a large proportion of T cells in the LP $(13,65,70,71,73,83,85)$, and plays a key role in antagonizing $\mathrm{S}_{1} \mathrm{P}_{1}$-mediated tissue egress. As with the IEL compartment, T cells in the LP express CD69 despite the absence of cognate antigen (83). In support of this, parabiosis experiments have revealed that although partner-derived cells include sizable proportion of $\mathrm{CD}^{-} 9^{-}$cells (which represent transients in the LP), nearly $80 \%$ of $\mathrm{CD}^{+} \mathrm{T}$ cells recruited from the partner become $\mathrm{CD}^{+} 9^{+}$following arrival (65), indicating the influence of constitutively secreted inflammatory cytokines in this tissue (83). However, the ratios of host and partner $\mathrm{CD} 8^{+} \mathrm{T}$ cells in the $\mathrm{LP}$ as well as the epithelium never become fully equilibrated following parabiosis, indicating the limitation of local instructive signaling for the formation of $\mathrm{T}_{\mathrm{RM}}$ cells in those tissues under steady-state conditions (65).

Following recruitment to the LP, $\mathrm{T}$ cells downregulate integrin $\alpha 4 \beta 7$, indicating that integrin $\alpha 4 \beta 7$ is not required for their retention (83). Instead, a proportion of $\mathrm{CD} 8^{+} \mathrm{T}$ cells upregulate 
CD103 in a TGF- $\beta$-dependent manner $(70,71,83,85)$. These cells form a resident population and are scattered throughout the $\mathrm{LP}$ (70) (Figure 2, shown as $\mathrm{CD}_{103^{+}} \mathrm{CD}^{+} \mathrm{T}_{\mathrm{RM}}$ ). Interestingly, $\mathrm{CD}_{103^{-}}$cells are also found to be resident in the LP (these cells are refractory to depletion by a systemically introduced antibody) (70), suggesting the presence of CD103-independent retention signals. These cells form clusters with CX3CR $1^{+}$macrophages primarily located under the crypts and the size of this population is independent of TGF- $\beta$, but is controlled by type I IFN and IL-12 (13) (Figure 2). Since these cytokines are provided mainly by monocyte-derived CCR2 ${ }^{+}$macrophages that have been recruited in response to local infection, and Cxcr3-deficient $\mathrm{CD}^{+} \mathrm{T}$ cells fail to form clusters (13), it is reasonable to conclude that infection-induced tissue conditioning facilitates the development of $\mathrm{CD} 103^{-} \mathrm{CD}^{+} \mathrm{T}_{\mathrm{RM}}$ population. However, the accumulation of $\mathrm{CD} 103^{-} \mathrm{CD}^{+} \mathrm{T}_{\mathrm{RM}}$ cells is also evident even in the absence of intestinal infection $(83,85)$, suggesting the presence of additional niches that sustain $\mathrm{CD} 103^{-} \mathrm{CD}^{+} \mathrm{T}_{\mathrm{RM}}$ cells in the infection/inflammation-inexperienced LP.

\section{Female Reproductive Tract (FRT)}

The mucosal surfaces of FRT can be divided into two types, referred to as type I and type II. The upper FRT, such as endometrium and endocervix, expresses type I mucosal surfaces, which are covered by a single layer of columnar epithelial cells linked by tight junctions. The lower FRT, such as the vagina and ectocervix, expresses type II mucosal surfaces, which are covered by multiple layers of non-keratinized stratified squamous epithelium binding to a basement membrane (102). Mucosa-associated lymphoid tissues (MALT) are found in the stromal layer (lamina propria) and the submucosa of the upper but not the lower FRT (103) (Figure 3). Migration of effector, as well as memory, T cells into the mucosa of the FRT is significantly restricted in the absence of local infection and/or inflammation (104). Once recruited, however, $\mathrm{T}_{\mathrm{RM}}$ cells are formed and maintained in both compartments under the control of local environmental cues.

The endometrium is a highly dynamic tissue in women. It undergoes remarkable cyclical changes of growth, differentiation, and degeneration under the control of the hormones estrogen and progesterone. The spontaneous decidualisation of the endometrial epithelium and stroma, which causes menstruation, and subsequent re-epithelization of endometrium periodically occurs (105), suggesting that limited, if any, anatomical niches are available for the long-term maintenance of $\mathrm{T}_{\mathrm{RM}}$ cells. Yet, numerous immune cells, including memory $\mathrm{T}$ cells, are found along the stroma/submucosa of the upper FRT $(106,107)$. During the proliferative phase of the menstrual cycle, uterine immune cells become condensed, leading to a formation of lymphoid aggregates (107). These lymphoid aggregates, which are presumably identical to the MALT described above, mainly consist of a B cell core surrounded by memory $\mathrm{CD}^{+} \mathrm{T}$ cells and macrophages $(107,108)$ (Figure 3$)$. The size of the MALT varies with the phase of the menstrual cycle, rising to $3,000-4,000$ cells during the secretory phase and declining to 300-400 cells

Lower FRT

Upper FRT

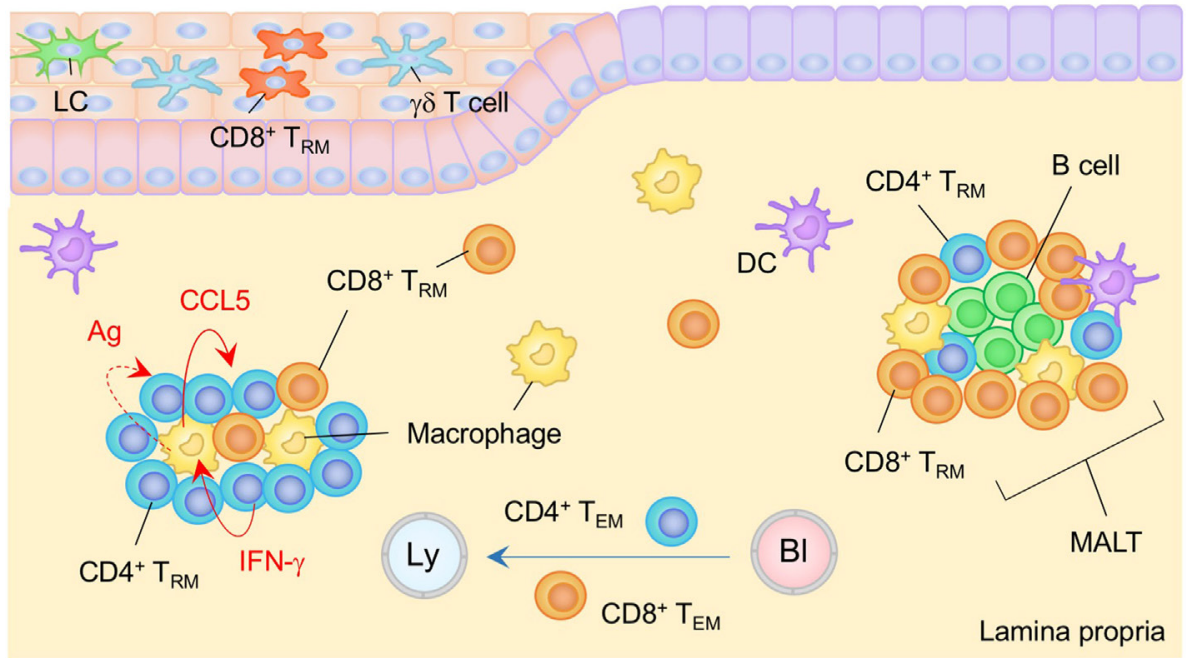

FIGURE 3 $\mid T_{R M}$ niches in the in the female reproductive tract (FRT). The FRT consist of the upper (endometrium and endocervix) and lower (vagina and ectocervix) reproductive tract. The upper FRT is composed of type I epithelia while the lower FRT is composed of type II epithelia. Mucosa-associated lymphoid tissues (MALT) are found in the lamina propria (LP) of the upper FRT. Both $C D 4^{+}$and $C D 8^{+} T_{R M}$ cells are involved in the MALT. The size of the MALT is regulated by the phase of the menstrual cycle. In the lower FRT, CD8 ${ }^{+} \mathrm{T}_{\mathrm{RM}}$ cells present mainly within the epithelial layers. Antigen is not required for the establishment of $\mathrm{CD} 8^{+} \mathrm{T}_{\mathrm{RM}}$ cells in this tissue. CD4+ $\mathrm{T}_{\mathrm{RM}}$ cells usually form clusters with macrophages in the LP. The structure of the cluster is sustained by a constitutively produced cytokine/chemokine network in which IFN- $\gamma$ secreted by CD4 ${ }^{+} T_{\mathrm{RM}}$ cells drives CCR5 production by macrophages, which attracts and retains CD4+ $\mathrm{T}_{\mathrm{RM}}$ cells within the cluster. Cognate antigen may be involved in driving CD4 ${ }^{+} \mathrm{T}$ cell production of IFN- $\gamma$. $\mathrm{T}_{\mathrm{EM}}$ pass through the LP. Orange and blue cells indicate CD8 ${ }^{+}$and $\mathrm{CD} 4^{+} \mathrm{T}_{\mathrm{RM}}$ Cells, respectively, unless otherwise stated. Red lines indicate the representative niche factors that influence the maintenance of $T_{\mathrm{RM}}$ cells. $A$ blue line indicates the migratory route. A dashed line indicates potential impact of niche factor. Abbreviations: Ly, lymph vessel; Bl, blood vessel; Ag, antigen; LC, Langerhans cells; $\mathrm{T}_{\mathrm{RM}}$, tissue-resident memory T cells; $T_{E M}$, effector memory T cells. 
during the proliferative phase (109). This implies that there must be endocrine regulation of the $\mathrm{T}_{\mathrm{RM}}$ niches. It is also known that $\mathrm{CD} 8^{+}$cytotoxic T lymphocyte (CTL) activity is suppressed during the secretory stage, presumably to minimize the recognition and rejection of allogenic sperm and the semi-allogenic fetus (107). Thus, the deployment of memory $\mathrm{CD}^{+} \mathrm{T}$ cells within the MALT in the uterine stroma/submucosa but not epithelial layer is organized to maintain reproductive function.

Recently, intravital imaging of the perimetrium and myometrium of the fallopian tubes has demonstrated the establishment of antigen-specific $\mathrm{CD}^{+} \mathrm{T}_{\mathrm{RM}}$ cells in the upper FRT following resolution of virus infection at the uterus (110). The velocity of $\mathrm{CD}^{+} \mathrm{T}_{\mathrm{RM}}$ cells in the uterine stroma $\left(\sim 10 \mu \mathrm{m} \mathrm{min}{ }^{-1}\right)$ is similar to that of $\mathrm{CD}^{+} \mathrm{T}_{\mathrm{CM}}$ cells in the $\mathrm{LN}$ and is significantly higher than that of $\mathrm{CD}^{+} \mathrm{T}_{\mathrm{RM}}$ in the skin epidermis $\left(\sim 2 \mu \mathrm{m} \mathrm{min}{ }^{-1}\right)$ $(35,110,111)$. Since uterine $\mathrm{CD}^{+} \mathrm{T}_{\mathrm{RM}}$ cells display poor dendritic morphology, as compared to skin $\mathrm{CD}^{+} \mathrm{T}_{\mathrm{RM}}$ cells, and are found in a site where immune cells are present at relatively high density $(35,110,112)$, it is likely that the $\mathrm{CD}^{+} \mathrm{T}_{\mathrm{RM}}$ cell niches in the upper FRT exist within the MALT in the uterine stroma/ submucosa. Furthermore, an experimental Chlamydia vaccine that promotes antigen presentation by immunogenic $\mathrm{CD} 11 \mathrm{~b}^{+}$

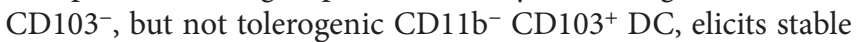
$\mathrm{CD}^{+} \mathrm{T}_{\mathrm{RM}}$ cell populations in the upper FRT. These cells provide significant protection against subsequent Chlamydia infection (113). The integrins $\alpha 4 \beta 1$ and $\alpha 4 \beta 7$ are involved in the migration of effector $\mathrm{CD}^{+} \mathrm{T}$ cells to this site as blockade of integrin $\alpha 4$ blocks uterine $\mathrm{T}$ cell homing during the early phase of infection (113-115). Large numbers of $\mathrm{CD}^{+} \mathrm{T}$ cells are recruited to the uterine stroma/submucosa after local infection with Chlamydia (116) and form clusters that also include small numbers of B cells and $\mathrm{CD}^{+} \mathrm{T}$ cells $(117,118)$. This indicates that $\mathrm{CD} 4^{+} \mathrm{T}_{\mathrm{RM}}$ cells in the upper FRT are also maintained in MALT structures (Figure 3). B cells in the cluster also act as APC to $\mathrm{CD} 4^{+} \mathrm{T}$ cells, leading to the selection and maintenance of highly protective $\mathrm{CD}^{+} \mathrm{T}_{\mathrm{RM}}$ cells $(108,119)$.

The immune cell composition of the lower FRT (type II epithelia) is basically similar to that of the skin: LC and $\gamma \delta \mathrm{T}$ cells survey the epithelium, while heterogeneous subsets of DC and macrophages survey the LP (103). Although the lower FRT does not contain MALT in the steady state, both $\mathrm{CD}^{+}$and $\mathrm{CD} 4^{+} \mathrm{T}_{\mathrm{RM}}$ cells can be established in the lower FRT following intravaginal infections, such as those mediated by herpes simplex virus type 2 (HSV-2). Notably, after the clearance of the infection, memory CD4 ${ }^{+}$T cells, B cells, DC, and macrophages form clusters beneath the epithelial layer of the vagina (120) (Figure 3). CD4 ${ }^{+} \mathrm{T}_{\mathrm{RM}}$ cells are predominantly distributed within the clusters, and their structures are sustained by a constitutively produced cytokine/ chemokine network. IFN- $\gamma$ secreted by $\mathrm{CD}^{+} \mathrm{T}_{\mathrm{RM}}$ cells drive CCL5 production by macrophages which attracts and retains $\mathrm{CD}^{+} \mathrm{T}_{\mathrm{RM}}$ cells within the cluster (15). Residual antigen may be involved in driving $\mathrm{CD}^{+} \mathrm{T}_{\mathrm{RM}}$ cell production of IFN- $\gamma(15)$. Although $\mathrm{CD}^{+} \mathrm{T}_{\mathrm{RM}}$ cells are crucial for full protection against HSV-2 infection (15), establishment of $\mathrm{CD}^{+} \mathrm{T}_{\mathrm{RM}}$ cells in the vaginal mucosa increases susceptibility to subsequent human immunodeficiency virus infection due an increase in the number of susceptible target cells $(121,122)$.
As with the skin epidermis, antigen-specific $\mathrm{CD} 8^{+} \mathrm{T}_{\mathrm{RM}}$ cells reside within the epithelium and LP of the vaginal mucosa (123-125). $\mathrm{T}_{\mathrm{RM}}$ cells in the vaginal LP are predominantly found in clusters (15). Migration of effector $\mathrm{CD}^{+} \mathrm{T}$ cells to the vaginal epithelium largely depends on CXCR3, a receptor for inflammatory chemokines CXCL9 and CXCL10 (126). IFN- $\gamma$ secreted by arriving $\mathrm{CD}^{+} \mathrm{T}$ cells triggers production of those chemokines at the site of infection, demonstrating the importance of $\mathrm{CD}^{+}$ $\mathrm{T}$ cells in promoting anti-viral $\mathrm{CD}^{+} \mathrm{T}$ cell responses in the FRT (126). Topical administration of these chemokines can effectively recruit circulating effector, but not memory, CD8 ${ }^{+}$ $\mathrm{T}$ cells primed at a remote site to the genital mucosa even in the absence of cognate antigen, a strategy known as "prime and pull." This leads to the establishment of long-term populations of $\mathrm{CD}^{+} \mathrm{T}_{\mathrm{RM}}$ cells in the vagina (127). Interestingly, although effector $\mathrm{CD}^{+}{ }^{+} \mathrm{T}$ cells are also recruited to the genital mucosa following prime and pull strategies, memory $\mathrm{CD} 4^{+} \mathrm{T}$ cells are not retained for the long term within the vagina (127), implying that the maintenance of $\mathrm{CD}^{+} \mathrm{T}_{\mathrm{RM}}$ niches (the clusters in the vaginal LP) relies on local antigen. By contrast, and similar to the skin CD8 ${ }^{+} \mathrm{T}_{\mathrm{RM}}$ cells that populate epidermal niches for DETC (16), $\mathrm{CD}^{+} \mathrm{T}$ cells recruited to the vaginal mucosa may occupy unique niches that were originally occupied by other resident cell types, such as $\gamma \delta$ T cells in the epidermal layer of the vagina. Distinct from the skin $\mathrm{CD}^{+} \mathrm{T}_{\mathrm{RM}}$ cells, however, the development and maintenance of $\mathrm{CD}^{+} \mathrm{T}_{\mathrm{RM}}$ cells in the FRT is IL-15-independent (99). Currently, the factors that regulate the maintenance of $\mathrm{T}_{\mathrm{RM}}$ cells in the FRT are largely unknown.

\section{Upper Respiratory Tract (URT) and Lower Respiratory Tract (LRT)}

The respiratory tract is divided into two compartments; the URT, comprised of the nasal cavities, pharynx, and larynx, and the LRT, comprised of the trachea, primary bronchi, and lungs. Although most studies have largely focused on $\mathrm{T}_{\mathrm{RM}}$ cells in the LRT, most common airborne pathogens in the human primarily infect the URT. Thus, understanding the $\mathrm{T}_{\mathrm{RM}}$ niches in both compartments is key for the development of vaccines that confer protection against respiratory pathogens.

The mucosal surface of the URT is comprised of pseudostratified ciliated columnar epithelial cells and an underlying LP. In mice, nasal-associated lymphoid tissues (NALT), the murine equivalent of the tonsils in human, are embedded directly in the submucosa at the base of the nasal cavities (128). NALT is considered to be a mucosal inductive site for humoral and cellular immune responses in the URT since it hosts B cell follicles surrounded by $T$ cell areas $(128,129)$. In contrast to the $\mathrm{LN}$, where naïve $\mathrm{CD} 4^{+} \mathrm{T}$ cells predominate over memory $\mathrm{T}$ cells, the NALT is surveyed primarily by memory $\mathrm{CD} 4^{+} \mathrm{T}$ cells, presumably resident type, suggesting that it is optimized to initiate memory recall responses, rather than initiate primary $\mathrm{T}$ cell responses (130). In contrast to memory CD4 ${ }^{+} \mathrm{T}$ cells in the NALT, CD8 $\mathrm{T}_{\mathrm{RM}}$ cells tend to be distributed throughout the nasal turbinate and septum, although some antigen-specific $\mathrm{CD}^{+} \mathrm{T}_{\mathrm{RM}}$ cells are also established in the NALT following recovery from a respiratory virus infection (131). In this regard, the distribution of T cells in the URT is similar to that in the skin and the FRT, 
where $\mathrm{CD}^{+} \mathrm{T}_{\mathrm{RM}}$ cells are widely distributed in the epithelial tissues and $\mathrm{CD}^{+} \mathrm{T}_{\mathrm{RM}}$ cells form clusters in the LP.

While the majority of $\mathrm{CD}^{+} \mathrm{T}_{\mathrm{RM}}$ cells in the nasal tissues express CD103, a small fraction of the cells are CD103 negative (131). This differential expression of CD103 may reflect the localization of $\mathrm{CD}^{+} \mathrm{T}_{\mathrm{RM}}$ cells within the epithelium and LP (132). Despite the high proportion of $\mathrm{CD}_{103^{+}}$cells in the URT, the differentiation of $\mathrm{CD}^{+} \mathrm{T}_{\mathrm{RM}}$ cells in the nasal tissues does not appear to be dependent on local signaling through TGF- $\beta$ and cognate antigen $(43,131,133)$. This is in stark contrast to the LRT where both of these factors are absolutely required for the establishment of $\mathrm{CD}^{+} \mathrm{T}_{\mathrm{RM}}$ cells $(134,135)$. Thus, the local instructions required for the differentiation of $\mathrm{CD}^{+} \mathrm{T}_{\mathrm{RM}}$ cells in the nasal mucosa are distinct from those in the LRT. Furthermore, the number of $\mathrm{CD}^{+} \mathrm{T}_{\mathrm{RM}}$ cells in the nasal tissues is relatively stable (there was no visible decline in number of these cells at least 3 months post-infection), whereas there is a significant decline in number of these cells in the LRT (lung) (131). This suggests that the nature of the anatomical niches that maintain $\mathrm{CD}^{+} \mathrm{T}_{\mathrm{RM}}$ cells differ between URT and LRT. Given the structural similarity between nasal mucosa and other mucosal tissues and the fact that the nasal tissues retain $\gamma \delta \mathrm{T}$ cells in the epithelium (136), it is tempting to speculate that $\mathrm{CD}^{+} \mathrm{T}_{\mathrm{RM}}$ cells in the nasal tissues may displace $\gamma \delta \mathrm{T}$ cells from their niches, potentially enabling their long-term survival.

The mucosal surfaces of the trachea and primary bronchus are basically similar to that of the nasal mucosa except for the presence of hyaline cartilage and a poorly developed venous plexus (the latter presumably helps avoid accidental suffocation caused by tracheal hemorrhage). Tracheal epithelial cells are a major target for several viral infections, such as seasonal influenza virus, and a recent study has demonstrated that large numbers of antigen-specific effector $\mathrm{CD} 8^{+} \mathrm{T}$ cells are recruited to the tracheal mucosa during the acute phase of the infection (137). By contrast, relatively few $\mathrm{CD}^{+} \mathrm{T}$ cells are recruited to the tracheal mucosa (as compared to the LRT) during the acute phase of infection. This suggests that there are distinct sets of homing signals in the mucosa of the trachea and LRT (137). Although establishment of CD8 ${ }^{+} \mathrm{T}_{\mathrm{RM}}$ cells in the trachea was not determined in this study, $\mathrm{CD}^{+} \mathrm{T}$ cells were still detectable in the trachea following the resolution of an influenza virus infection (day 14), suggesting that some of these cells may reside in the tracheal epithelium as $\mathrm{T}_{\mathrm{RM}}$.

The mucosa of the LRT is covered by pseudostratified ciliated epithelium (bronchiole) and columnar epithelium (terminal bronchiole to alveoli). A relatively thin interstitium underlies the epithelium and hosts both blood and lymphatic vessels. $\mathrm{T}$ cells in the LRT reside in at least two distinct compartments: the lung interstitium and the lung airways. $\mathrm{T}$ cells resident in the lung interstitium can be identified, and distinguished from circulating $\mathrm{T}$ cells, by intravenous labeling with an anti- $\mathrm{T}$ cell antibody (138). T cells in the lung airway are those that are collected by bronchoalevolar lavage taken via the trachea (139). Most of these cells are derived from the LRT (localized in the epithelial layer), although a few cells are also derived from the URT (trachea). CD8 ${ }^{+} \mathrm{T}$ cells exhibiting memory phenotypes can be detected in the LRT of naive animals or animals that had previously been infected or vaccinated at sites distant from the lung $(6,43,50,140-143)$. It is believed that there is a basal level of influx that enables continual surveillance of the lung by antigen-experienced $\mathrm{CD}^{+} \mathrm{T}$ cells in the "lung-unconditioned" animals. For instance, some blood-borne cells are recruited to the airway under steady-state condition and CXCR3 expressed on antigen-experienced $\mathrm{CD} 8^{+} \mathrm{T}$ cells is known to be involved in this process (140). Once recruited to the lung airways, $\mathrm{T}$ cells do not return to the interstitium or the circulation unless there is an infection or an inflammatory condition (144).

Upon pulmonary infection, epithelial cells, lung-resident populations of immune cells in the interstitium and airway epithelium (such as macrophages, DC, and ILC) cooperatively promote acute inflammation (145). Although the full array of adhesion molecules and chemokine receptors that specifically guide $\mathrm{T}$ cells to the lung has not yet been determined, it is known that CXCR3 is important for the recruitment of effector CD8 ${ }^{+}$ $\mathrm{T}$ cells to the epithelial layer of the interstitium as well as the airway (146). In addition, local inflammation-induced upregulation of CD69, and the activation of integrin $\alpha 1 \beta 1$ (very late antigen-1, CD49a) promotes transient localization and retention of $\mathrm{CD}^{+} \mathrm{T}$ cells in the lung interstitium $(134,147)$. As with the other mucosal tissues, local TGF- $\beta$ signaling is required for the expression of CD103 on $\mathrm{CD}^{+} \mathrm{T}$ cells in the lung $(135,148)$, which then promotes localization of $\mathrm{CD}^{+} \mathrm{T}$ cells along the walls of large airways (149). IL-15 [produced primarily by CD11b macrophages in the interstitium during the early phases of a respiratory infection (150)] also facilitates the migration of effector $\mathrm{CD}^{+} \mathrm{T}$ cells to the lung (151). However, IL-15 is dispensable for the differentiation and maintenance of $\mathrm{CD} 8^{+} \mathrm{T}_{\mathrm{RM}}$ cells in the lung (152).

Following the resolution of infection, substantial numbers of memory $\mathrm{CD}^{+} \mathrm{T}$ cells are maintained in both the lung interstitium and the airways for several months (153). We have recently shown that memory $\mathrm{CD}^{+} \mathrm{T}$ cells in both of these sites comprise a mixture of two distinct memory $\mathrm{T}$ cell populations: a major, stable population of $\mathrm{T}_{\mathrm{RM}}$ cells, and a minor, dynamic population of $\mathrm{T}_{\mathrm{EM}}$ cells that is continuously replenished by new cells from the circulation (134) (Figure 4). We also identified specific anatomical niches for $\mathrm{CD}^{+} \mathrm{T}_{\mathrm{RM}}$ cells around the bronchiole, which are temporarily created at sites of regeneration following tissue injury (134). We termed these sites repair-associated memory depots (RAMD). As with the epithelial layers in other mucosal surfaces, $\mathrm{CD}^{+} \mathrm{T}_{\mathrm{RM}}$ cells in the RAMD do not form clusters or lymphoid-like structures, but instead accumulate to relatively high densities in specific niches. By contrast, $\mathrm{CD} 8^{+} \mathrm{T}_{\mathrm{EM}}$ cells are widely, but sparsely, distributed throughout the unaffected lung interstitium. This rigid compartmentalization of memory CD8 ${ }^{+}$ $\mathrm{T}$ cell populations in the lung suggests that the two populations are maintained by separate signals. It is also important to note that residual antigen-driven reactivation in the mediastinal LN plays a role in driving the continual recruitment of $\mathrm{CD}^{+} \mathrm{T}_{\mathrm{EM}}$ cells to the lung for several months after infection (154-157). Local instructive signals induced by pulmonary infection, such as IL-33 and TNF, presumably also contribute to the transient retention of circulating $\mathrm{CD}^{+} \mathrm{T}_{\mathrm{EM}}$ cells in the lung interstitium (157). A more detailed analysis of the factors and mechanisms 


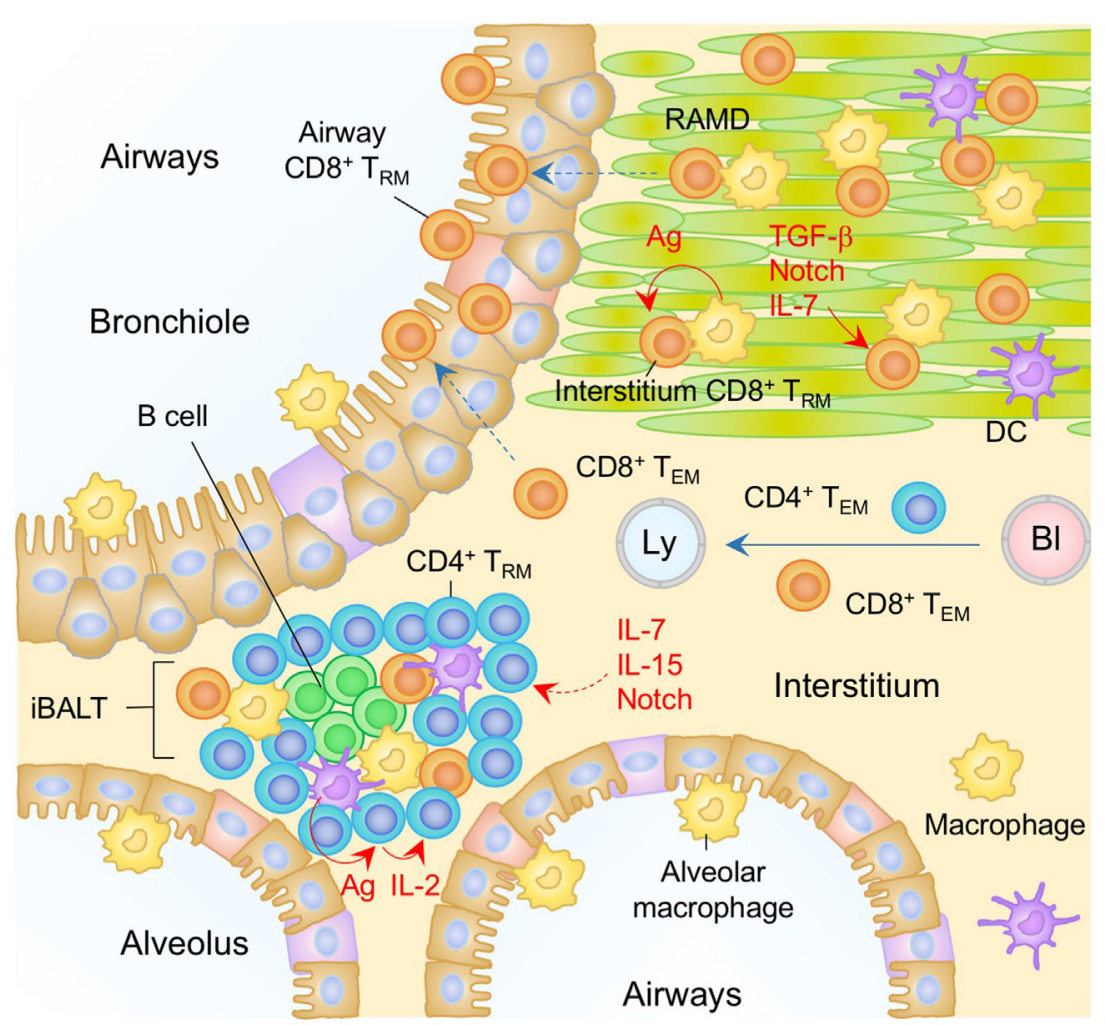

FIGURE 4 | $T_{\text {RM }}$ niches in the in the lung. A majority of CD8 ${ }^{+} T_{\text {RM }}$ cells in the lung interstitium are maintained within the repair-associated memory depots (RAMD) that are temporarily created at the site of tissue injury, while CD8 ${ }^{+} \mathrm{T}_{\mathrm{RM}}$ cells are found sparsely in the unaffected areas. A complex of niche factors, including signals via cognate antigen, TGF- $\beta$, Notch, and IL-7, are known to be involved in the formation of CD8 ${ }^{+} \mathrm{T}_{\mathrm{RM}}$ cells in the lung interstitium. CD8 ${ }^{+} \mathrm{T}_{\mathrm{RM}}$ cells are also present in the lung airways, the number of which is presumably maintained by continual recruitment of cells from the pool of CD8 ${ }^{+} T_{R M}$ cells in the lung interstitium. CD4+ $T_{R M}$ cells in the lung interstitium are maintained predominantly within the inducible bronchus-associated lymphoid tissues (iBALT). Late antigen recognition triggers autocrine IL-2 signaling, which supports the proliferation and survival of CD4+ $\mathrm{T}_{\mathrm{RM}}$ cells. Homeostatic cytokines IL-7 and IL-15, and Notch signaling are also required for the maintenance of $\mathrm{CD}^{+} \mathrm{T}_{\mathrm{RM}}$ cells in the iBALT. $\mathrm{T}_{\mathrm{EM}}$ cells are passing through the normal interstitium. Orange and blue cells indicate $\mathrm{CD} 8^{+}$and $\mathrm{CD} 4{ }^{+} \mathrm{T}_{\mathrm{RM}}$ cells, respectively, unless otherwise stated. Red lines indicate the representative niche factors that influence the maintenance of $\mathrm{T}_{\mathrm{RM}}$ cells. $\mathrm{A}$ blue line indicates the migratory route. Dashed lines indicate potential impact of niche factors (red) or migratory routes (blue). Abbreviations: Ly, lymph vessel; BI, blood vessel; Ag, antigen; $T_{R M}$, tissue-resident memory $T$ cells; $T_{E M}$, effector memory $T$ cells.

that regulate the continual recruitment of memory $\mathrm{CD}^{+} \mathrm{T}$ cells to the lung has been presented in our previous review (5).

Interestingly, in our parabiosis experiments we also detected minimal, if any, conversion of $\mathrm{CD}^{+} \mathrm{T}_{\mathrm{EM}}$ cells into $\mathrm{CD} 8^{+} \mathrm{T}_{\mathrm{RM}}$ cells in the lung for several months post-infection, a time period when $\mathrm{T}_{\mathrm{RM}}$ cells still comprise a large proportion of memory $\mathrm{CD}^{+} \mathrm{T}$ cell pool in the lung (134). These studies further demonstrated that $\mathrm{CD}^{+} \mathrm{T}$ cells recruited to the lung interstitium after the peak of the cellular immune response (around day 10 post-infection) are excluded from the RAMD, and fail to form $T_{R M}$ cells (134). These data clearly demonstrated that $T_{R M}$ niches in the lung interstitium are occupied at the peak of tissue damage, but are no longer available for latecomer $\mathrm{CD}^{+} \mathrm{T}$ cells. In the skin and FRT sections, we noted that forced recruitment of $\mathrm{CD}^{+} \mathrm{T}$ cells to the epithelial tissues by antigen-independent inflammation or topical administration of chemokines results in the establishment of $\mathrm{T}_{\mathrm{RM}}$ cells (prime and pull) $(37,127)$. Importantly, however, we and others have demonstrated that this prime and pull strategy does not work for the establishment of $\mathrm{CD}^{+} \mathrm{T}_{\mathrm{RM}}$ cells in the lung, as $\mathrm{CD} 8^{+} \mathrm{T}$ cells recruited to the lung by antigen-independent inflammation in the lung completely disappear after the inflammation in the lung has resolved $(134,158)$. The failure of the prime and pull strategy in the lung is likely due to the structural difference between the lung and other mucosal/surface tissues. For instance, skin $\mathrm{CD}^{+} \mathrm{T}_{\mathrm{RM}}$ cells can occupy DETC niches in the epidermis for their long-term survival, whereas normal lung mucosa does not exhibit such preformed niches. Administration of cognate antigen in combination with the prime and pull strategy results in the de novo creation of the RAMD, and significantly increases the numbers of antigen-specific, but not antigen-unrelated, $\mathrm{CD}^{+} \mathrm{T}_{\mathrm{RM}}$ cells in the lung interstitium and airways (134). This indicates that local antigen plays at least two distinct roles: the creation of damageassociated niches by generating antigen-bearing target cells in the lung in the presence of antigen-specific $\mathrm{CD}^{+} \mathrm{T}$ cells in the circulation, and the antigen signaling necessary for the establishment, and/or survival, of $\mathrm{T}_{\mathrm{RM}}$ (159). Following the establishment of $\mathrm{T}_{\mathrm{RM}}$, Notch signaling may be a potential niche factor that regulates the maintenance of $\mathrm{T}_{\mathrm{RM}}$ cells in the lung, as the lack of Notch signaling results in the loss of $\mathrm{CD} 103^{+} \mathrm{CD}^{+} \mathrm{T}_{\mathrm{RM}}$ cells from the 
lung (160). Although cells that express Notch ligands are not yet identified in the RAMD, cell to cell contact seems important for sustaining $\mathrm{T}_{\mathrm{RM}}$ cells in the lung. It is noteworthy that the size of the RAMD shrinks over time as tissue repair proceeds and tends to disappear several months post-infection (134). Such a transitional appearance of RAMD may account for the relatively shorter longevity of $\mathrm{CD}^{+} \mathrm{T}_{\mathrm{RM}}$ cells in the lung (149). Recently, Zhou et al. have reported that the addition of local 4-1BB signaling during recall (4-1BB is expressed mainly on memory but not naive $\mathrm{T}$ cells) improves the generation of long-lived $\mathrm{CD} 8^{+} \mathrm{T}_{\mathrm{RM}}$ cells expressing IL-7 receptor (IL-7R) $\alpha$ (161), suggesting that IL-7 plays a key role in the maintenance of $\mathrm{CD} 8^{+} \mathrm{T}_{\mathrm{RM}}$ cells in the lung. It will be interesting to determine whether these cells can survive outside the RAMD.

In contrast to the lung interstitium, the histological nature of putative $\mathrm{CD}^{+} \mathrm{T}_{\mathrm{RM}}$ niches in the lung airways remains unclear. It has long been believed that the numbers of memory $\mathrm{CD}^{+} \mathrm{T}$ cells in the lung airways are maintained by the continual recruitment from the circulation. Resident cells at this site are cleared by phagocytic cells or removed through mucociliary clearance, resulting in a relatively short half-life ( 2 weeks) (144). Surprisingly, our parabiosis experiments have demonstrated no evidence for the continual replacement of host memory CD8 ${ }^{+} \mathrm{T}$ cells in the lung airways by $\mathrm{CD} 8^{+} \mathrm{T}_{\mathrm{EM}}$ cells derived from the partner. Since it is unlikely that memory $\mathrm{CD}^{+} \mathrm{T}$ cells can persist for long within the harsh airway environment, we assume that cells in the airways are continually replenished by $\mathrm{CD}^{+} \mathrm{T}_{\mathrm{RM}}$ cells from the RAMD (interstitium) but not by $\mathrm{CD}^{+} \mathrm{T}_{\mathrm{EM}}$ cells from the circulation. Thus, the major source of $\mathrm{CD}^{+} \mathrm{T}$ cells in the lung airways may be RAMD located underneath the bronchoalveolar walls (Figure 4).

In contrast to $\mathrm{CD} 8^{+} \mathrm{T}_{\mathrm{RM}}$ cells, most $\mathrm{CD} 4^{+} \mathrm{T}_{\mathrm{RM}}$ cells in the lung are found in $\mathrm{B}$ cell follicles and are surrounded by $\mathrm{T}$ cell areas (134, 162-164) (Figure 4). Such lymphoid-like structures have been termed inducible bronchus-associated lymphoid tissues (iBALT) and are the primary niches for the maintenance of lung $\mathrm{CD}^{+} \mathrm{T}_{\mathrm{RM}}$ cells. The factors regulating the development of iBALT are reviewed elsewhere (165). Several other physiological niches for the generation and maintenance of lung $\mathrm{CD} 4^{+} \mathrm{T}_{\mathrm{RM}}$ cells have also been reported. As with the $\mathrm{CD}^{+} \mathrm{T}_{\mathrm{RM}}$ cells, local antigen also plays a role (163), as late antigen recognition at day 5-8 postinfection, which has been termed a "memory check point," is necessary for the formation of memory $\mathrm{CD} 4^{+} \mathrm{T}$ cells in the lung and spleen (166). Antigen reactivation of the cells triggers autocrine IL-2 signaling, which prolongs the survival of $\mathrm{CD} 4^{+} \mathrm{T}_{\mathrm{RM}}$ cells by upregulating the IL-7R $\alpha(166-168)$ and sustains the homeostasis of lung $\mathrm{CD}^{+} \mathrm{T}_{\mathrm{RM}}$ cells $(162,164)$. Interestingly, IL-15 signaling, as opposed to IL-2 signaling, can generate a separate but similar cohort of highly functional and protective $\mathrm{CD} 4^{+} \mathrm{T}_{\mathrm{RM}}$ cells in the lung (169). As with the $\mathrm{CD}^{+} \mathrm{T}_{\mathrm{RM}}$ cells, increased transcription levels of Notch signaling-associated molecules are observed in lung $\mathrm{CD}^{+} \mathrm{T}_{\mathrm{RM}}$ cells, suggesting the involvement of Notch signaling for the maintenance of lung $\mathrm{CD}^{+} \mathrm{T}_{\mathrm{RM}}$ cells (170).

\section{Salivary Gland (SG)}

The SGs are exocrine epithelial tissues that secrete saliva into the oral cavity. Humans and rodents have at least three pairs of major SGs (parotid, sublingual, and submandibular) and each gland has secretory units composed of an acinus, myoepithelial cells, and a duct (171). SGs also function as an effector site for IgA-mediated humoral immune responses that protect oral surfaces $(172,173)$.

It is well known that the SGs can be a target of a variety of bacterial as well as viral infections, such as mumps and cytomegalovirus (CMV). In the case of CMV, the virus is able to establish latent infection in the SGs and is able to evade $\mathrm{CD}^{+}$ $\mathrm{T}$ cell immunity by downregulating MHC class I molecules (174). Virus-specific CD4 ${ }^{+} \mathrm{T}$ cells can control viral production, but are not able to eliminate latently infected cells $(175,176)$ such that persistent virus is selectively sequestered in the vacuoles of glandular acinar epithelial cells $(177,178)$. In latently infected individuals, resident populations of antigen-specific $\mathrm{CD}^{+}$and $\mathrm{CD}^{+} \mathrm{T}_{\mathrm{RM}}$ cells are established in the SGs $(179,180)$ (Figure 5). However, their phenotypes, localization, and the local cues regulating their differentiation into $\mathrm{T}_{\mathrm{RM}}$, differ significantly (181). $\mathrm{CD}^{+} \mathrm{T}_{\mathrm{RM}}$ cells are located predominantly in the stroma of the SGs and their establishment depends on local antigen (179), presumably due to the upregulation of CD69 that antagonizes $\mathrm{S}_{1} \mathrm{P}_{1}$-medaited tissue egress (181). By contrast, $\mathrm{CD}^{+} \mathrm{T}_{\mathrm{RM}}$ cells express CD103, and localize predominantly within the epithelium of the acini and ducts $(179,180)$ (Figure 5). Local TGF- $\beta$ signaling in the SGs is required for upregulation of CD103 on

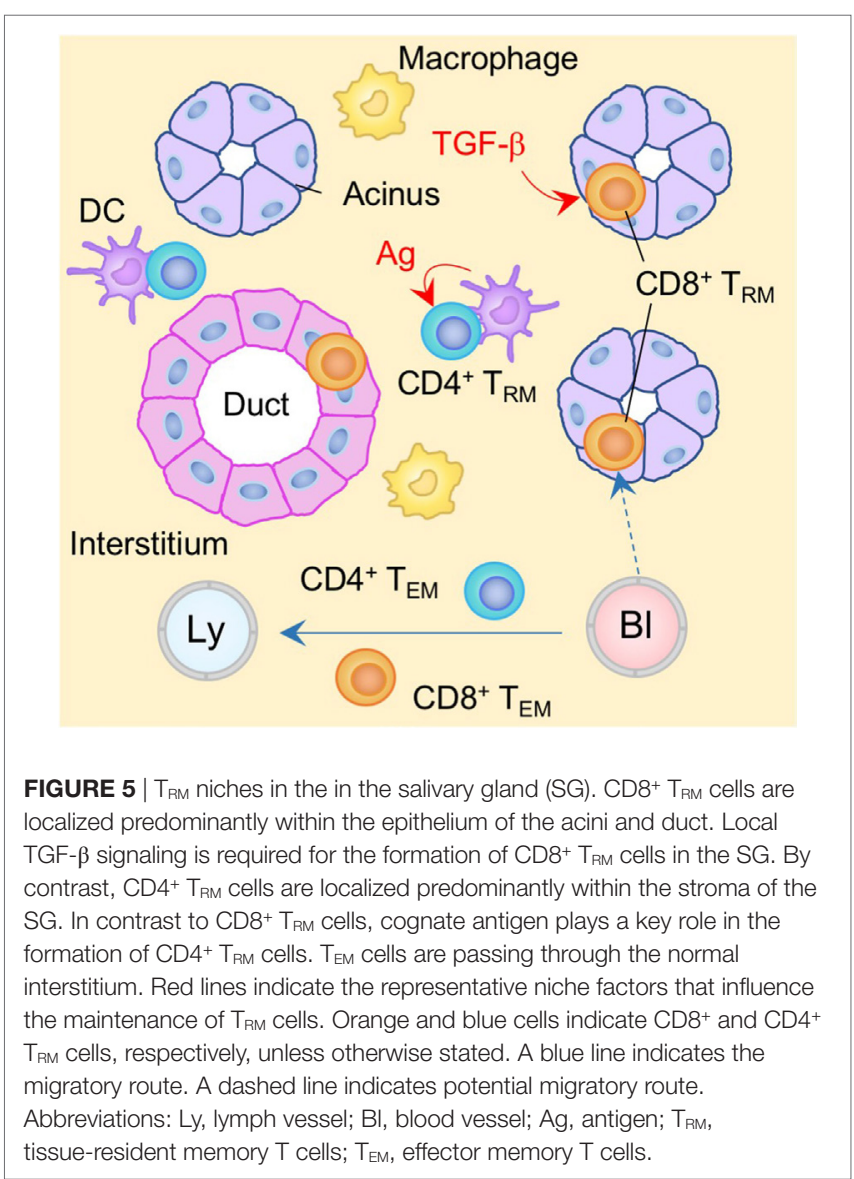


$\mathrm{CD}^{+} \mathrm{T}_{\mathrm{RM}}$ cells and their localization into the epithelium (179, 180). Because CMV downregulates MHC class I molecules, particularly in infected acinar glandular epithelial cells in the SGs, local antigen does not appear to be required for the formation of $\mathrm{CD}^{+} \mathrm{T}_{\mathrm{RM}}$ cells in the SGs (179). Indeed, virus-specific $\mathrm{CD}^{+} \mathrm{T}$ cells can be established in the SGs even in the absence of virus infection in this tissue $(6,182,183)$. Furthermore, ongoing presentation of late antigens by non-hematopoietic cells in the LN or by virus-uninfected APC (via cross-presentation) during CMV infection results in substantial and sustained expansion of antigen-specific $\mathrm{CD}^{+} \mathrm{T}$ cells in the circulation, a process known as memory inflation (184-187). Some of these memory CD8 ${ }^{+}$ $\mathrm{T}$ cells are also converted into $\mathrm{T}_{\mathrm{RM}}$ cells in the SGs on a continual basis (180). Blockade of CXCR3, or the genetic deletion of either integrin $\alpha 4 \beta 1$ or E-cadherin on $\mathrm{CD}^{+} \mathrm{T}$ cells reduces the accumulation of $\mathrm{CD}^{+} \mathrm{T}_{\mathrm{RM}}$ cells in the SGs $(182,183,188)$, suggesting that these molecules promote the migration of circulating $\mathrm{CD} 8^{+}$ $\mathrm{T}$ cells to the glandular epithelium. In contrast to the inability of the primary $\mathrm{CD}^{+} \mathrm{T}$ cell response to control the virus infection, $\mathrm{CD}^{+} \mathrm{T}_{\mathrm{RM}}$ cells resident in the SGs can confer protection upon recall by eliminating CMV infected non-epithelial cells, where $\mathrm{CMV}$ fails to achieve complete downregulation of MHC class I molecule (179).

\section{Non-Barrier Tissues \\ Brain}

Owing to the presence of the blood-brain barrier (BBB), the blood-cerebrospinal fluid (CSF) barrier (BCSFB), and the CSF-brain barrier, the central nervous system (CNS) is regarded as an immune privileged site with severely limited ingress of blood-borne $\mathrm{T}$ lymphocytes. Relatively few, if any, $\mathrm{T}$ cells are present in the healthy brain parenchyma under noninflammatory conditions (189). Consequently, the aberrant accumulation of $\mathrm{T}$ cells in the brain parenchyma has generally been considered to be a pathogenic condition. However, it is now becoming clear that the few peripheral $\mathrm{T}$ cells present in the brain in the absence of inflammation play key a role in surveying the CNS and keeping the infectious pathogens in check (190), as the lack of these cells can result in opportunistic infections in the CNS (191).

The choroid plexus (CP) is recognized as a major gateway for peripheral T cell access to the CNS $(192,193)$. The CP is comprised of fenestrated blood capillaries lacking endothelial tight junctions (192). Thus, the barrier properties of the BCSFB at this site rely only on the monolayer of epithelial cells interconnected by tight junctions-a structure permissive for immune cell transit (192). Consequently, around 150,000-750,000 immune cells are present in the CSF of healthy individuals, and more than $90 \%$ of the $\mathrm{T}$ cells present are antigen-experienced (193). Recent studies have identified a lymphatic vessel network lining the dural sinuses that drain CSF and allow the transit of immune cells from the adjacent subarachnoid space and brain interstitial fluid to the cervical LN $(194,195)$. This implies that there is the continual trafficking of $\mathrm{T}_{\mathrm{EM}}$ cells between CNS (e.g., meninges and FSC) and the circulation (196). Nevertheless, the brain parenchyma essentially lacks lymphatic vessels and is mostly devoid of T cells under steady-state conditions.
Upon infection with neurotropic pathogens, antigen-specific $T$ cells infiltrate the subarachnoid spaces of the meninges as well as the perivascular spaces of the parenchymal post-capillary venule, where specialized APC reside (197, 198) (Figure 6). $\mathrm{T}$ cells are then activated to proliferate and produce cytokines and chemokines in the infected meninges (199-201). This results in local inflammation, which subsequently disrupts vascular tight junctions and the glia limitans, allowing infiltration of T cells into the parenchyma $(190,198)$ (Figure 6). During this process, the balance of local chemokine production regulates the transmigration of circulating $\mathrm{T}$ cells into the brain parenchyma (202). In brief, CXCL12 is constitutively expressed on the basolateral surface of endothelial cell layer in the CNS and is also upregulated during inflammation, which promotes CXCR $4^{+} \mathrm{T}$-cell recruitment to, and retention within, the perivascular space $(203,204)$. It is only after the local concentration of CXCL12 declines that effector $\mathrm{T}$ cells are able to migrate into the brain parenchyma in response to inflammatory chemokines, such as ligands for CXCR3 $(205,206)$ and CCR5 $(207,208)$. In the case of neuroinflammation associated with experimental autoimmune encephalomyelitis, the CXCL10-CXCR3 axis also functions to retain T cells within the perivascular space presumably due to differential inflammatory nature in the perivascular space (209).

After the clearance of a viral infection in the CNS, some of the antigen-specific $\mathrm{CD} 8^{+} \mathrm{T}$ cells that had been recruited to the brain parenchyma differentiate into $\mathrm{T}_{\mathrm{RM}}$ cells and become resident in the site (133). The numbers of $\mathrm{CD} 8^{+} \mathrm{T}_{\mathrm{RM}}$ cells that establish residency depends on the pathogen and is presumably linked to the tropism and pathogenesis of each virus (210). For example, following intranasal infection with vesicular stomatitis virus, which infects nerve endings, $\mathrm{CD} 8^{+} \mathrm{T}_{\mathrm{RM}}$ cells form clusters at the site of infection, and are widely distributed throughout the brain parenchyma (133). By contrast, intracerebral infection with LCMV, which infects non-neuronal cells in the brain (i.e., glial cells), $\mathrm{CD} 8^{+} \mathrm{T}_{\mathrm{RM}}$ cell populations are primarily established at brain surface structures, such as meninges and CP (around the ventricles or at anatomical borders between different brain regions) (211). In both cases, these $\mathrm{CD}^{+} \mathrm{T}_{\mathrm{RM}}$ cell populations are not pathogenic, but confer protection against reinfection even in the absence of circulating memory $\mathrm{CD}^{+} \mathrm{T}$ cells (211).

Regardless of their location and the nature of the infecting pathogens, brain $\mathrm{CD}^{+} \mathrm{T}_{\mathrm{RM}}$ cells can be divided into at least two populations based on their expression of CD103 (133, 211-214). It has been proposed that the initial upregulation of CD103 is largely dependent on the local reactivation of $\mathrm{CD}^{+} \mathrm{T}$ cells with cognate antigen in the brain (it remains elevated following antigen clearance) (133). However, it is clear that Treg-derived TGF- $\beta(215,216)$, inflammation, and other undefined local factors (213), can also upregulate CD103 on $\mathrm{CD}^{+} \mathrm{T}_{\mathrm{RM}}$ cells in the brain in an antigen-independent manner. These different types of instructive signals may account for the distinct gene expression profiles between $\mathrm{CD}_{103}{ }^{+}$and $\mathrm{CD} 103^{-} \mathrm{CD}^{+} \mathrm{T}_{\mathrm{RM}}$ cells $(212,214)$ and the superior effector functions for the former $(213,214)$. It is noteworthy that retroviral knockdown of CD103 impairs the accumulation of $\mathrm{CD}^{+} \mathrm{T}_{\mathrm{RM}}$ cells in the brain, indicating the 


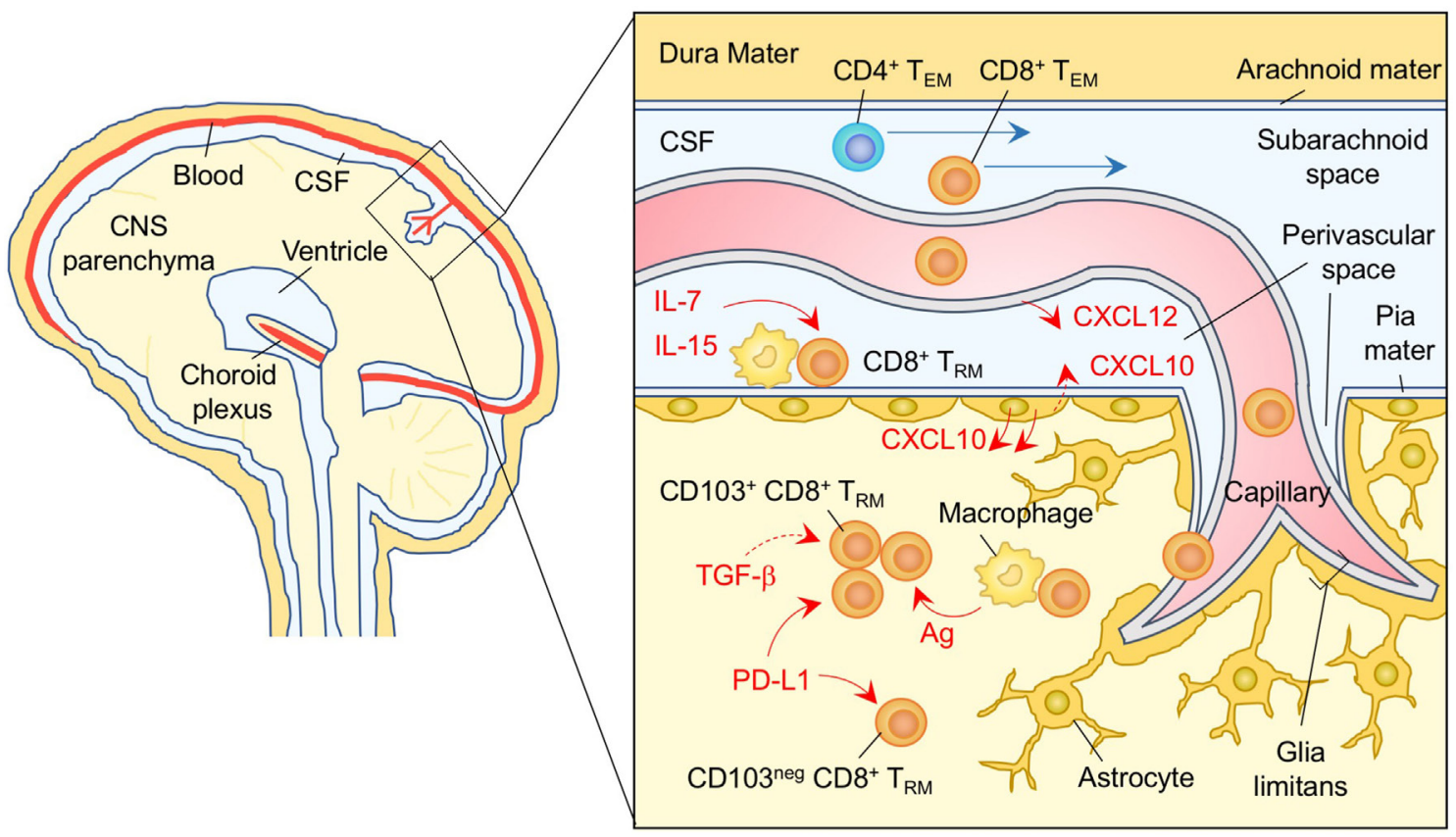

FIGURE 6 | $T_{\text {RM }}$ niches in the in the brain. CXCL12 is constitutively expressed on the basolateral surface of endothelial cells, and recruits CXCR4+ CD8 ${ }^{+} T$ cells to the perivascular spaces. Subsequent migration of cells in the brain parenchyma is promoted by chemokines such as ligands for CXCR3 and CCR5 secreted by astrocytes. $\mathrm{CD}^{+} \mathrm{T}_{\mathrm{RM}}$ cells are established in the parenchyma and perivascular spaces of the brain. Parenchymal $\mathrm{CD} 8^{+} \mathrm{T}_{\mathrm{RM}}$ cells are divided by the expression of CD103. Although upregulation of CD103 depends largely on cognate antigen, TGF- $\beta$ may be involved in this process. PD- 1 is highly expressed on both CD103+ and $\mathrm{CD}_{103}-\mathrm{CD} 8^{+} \mathrm{T}_{\mathrm{RM}}$ cells in the brain parenchyma independent of either antigen or inflammatory signals. Signaling through PD-1 promotes the establishment of $\mathrm{CD}^{+} \mathrm{T}_{\mathrm{RM}}$ cells in the brain parenchyma. IL-7 and IL-15 are available in the perivascular spaces, and sustain the homeostatic proliferation of CD8 ${ }^{+} \mathrm{T}_{\mathrm{RM}}$ cells in this compartment. $T_{E M}$ cells are passing through the cerebrospinal fluid (CSF). Orange and blue cells indicate CD8 ${ }^{+}$and CD4+ $T_{R M}$ cells, respectively, unless otherwise stated. Red lines indicate the representative niche factors that influence the maintenance of $\mathrm{T}_{\mathrm{RM}}$ cells. Blue lines indicate the migratory route. Dashed lines indicate potential impact of niche factors. Abbreviations: Ag, antigen; neg, negative; $T_{\mathrm{RM}}$, tissue-resident memory $\mathrm{T}$ cells; $\mathrm{T}_{\mathrm{EM}}$, effector memory $\mathrm{T}$ cells.

importance of CD103 for the recruitment and/or retention of $\mathrm{CD}^{+} \mathrm{T}$ cells early after infection, probably during transmigration through the $\mathrm{BBB}$. Once recruited to the brain parenchyma, however, CD103 expression has no impact on the localization of $\mathrm{CD}^{+} \mathrm{T}_{\mathrm{RM}}$ cells (211), which may be attributed to the lack of E-cadherin expression in the adult brain (217). Taken together, it is possible that CD103 expressed on brain CD8 ${ }^{+} \mathrm{T}_{\mathrm{RM}}$ cells may reflect the prior acquisition of local education but is not functional as an adhesion molecule.

Programmed cell death protein 1 (PD-1) and CD69 are both expressed on $\mathrm{CD}^{+} \mathrm{T}_{\mathrm{RM}}$ cells in the brain (including both $\mathrm{CD}_{103^{+}}$and $\mathrm{CD}_{103^{-}} \mathrm{T}_{\mathrm{RM}}$ ) (213). Although the expression of both molecules on $\mathrm{CD}^{+} \mathrm{T}_{\mathrm{RM}}$ in non-CNS sites is generally dependent on repetitive antigen engagement (218), it has been demonstrated that both antigen and inflammation are dispensable for the sustained expression of PD-1 as well as CD69, and programmed cell death ligand 1 (PD-L1) in the brain (213). Furthermore, these cells remain functionally competent under these conditions (213). Interestingly, PD-1 expression on brain $\mathrm{CD}^{+} \mathrm{T}_{\mathrm{RM}}$ cells is found to be programmed, as environmental factors in the brain induce extensive demethylation of the $P d c d 1$ promoter (which controls PD-1 expression) (213). In addition, genetic deletion of either PD-1 or PD-L1 diminishes the establishment of brain $\mathrm{CD}^{+} \mathrm{T}_{\mathrm{RM}}$ cells $(219,220)$.
These findings suggest that signaling through PD-1 is a part of the $\mathrm{T}_{\mathrm{RM}}$ differentiation program and may be attributed to the PD-1 signaling-induced upregulation of CPT1a, an enzyme necessary for fatty acid $\beta$-oxidation that promotes memory differentiation $(221,222)$. Since upregulation of PD-L1 expression is evident on parenchymal cells (e.g., microglia, astrocytes, and oligodendrocytes) following different types of viral infections in the CNS (223-227), it is reasonable to speculate that PD-1 expression by brain $\mathrm{CD}^{+} \mathrm{T}_{\mathrm{RM}}$ cells maintains a tolerable balance between immunopathology and immune control of the virus in the CNS (190).

Reports of Ki-67 expression on brain $\mathrm{CD}^{+} \mathrm{T}_{\mathrm{RM}}$ cells following resolution of virus infection suggests that these cells are maintained by homeostatic proliferation (211). $\mathrm{CD}^{+} \mathrm{T}_{\mathrm{RM}}$ cells located at the brain surface structures more frequently express Ki-67 and phosphorylated Stat5 than those in the brain parenchyma, suggesting that their anatomical location allows them access to the homeostatic cytokines, IL-7 and IL-15 (211). Furthermore, $\mathrm{CD}^{+} \mathrm{T}_{\mathrm{RM}}$ cells in the brain parenchyma are less responsive to homeostatic cytokines (212). Interestingly, $\mathrm{CD}^{+} \mathrm{T}_{\mathrm{RM}}$ cells in the brain parenchyma, especially the $\mathrm{CD}_{103^{+}}$population, are not able to survive outside their tissue niche. The irreversible nature of tissue adaptation by $\mathrm{CD}^{+} \mathrm{T}_{\mathrm{RM}}$ cells in the brain parenchyma is very different to the situation in the lung airway where CD8 ${ }^{+}$ 
$\mathrm{T}_{\mathrm{RM}}$ cells retain the plasticity to adapt to different environmental niches for their survival $(133,228)$.

\section{Liver}

The liver is a frontline immune tissue in which antigen-rich blood from the gastrointestinal tract enters via the portal vein and is passed through a network of sinusoids (the capillary bed of the liver). Antigens are effectively trapped by sinusoidal resident APC, such as Kupffer cells, liver sinusoidal endothelial cells (LSEC), and DC (229), and the relatively slow sinusoidal blood flow promotes effective interaction of circulating immune cells with these APC (230). Fenestrated sinusoidal endothelium also enables the direct surveillance of hepatocytes by circulating T cells (231).

Recent studies have demonstrated that liver-resident memory $\mathrm{CD}^{+} \mathrm{T}$ cells are established in the sinusoid following systemic infection or vaccination (232) (Figure 7). Liver CD8 ${ }^{+}$ $\mathrm{T}_{\mathrm{RM}}$ cells in mice are mostly $\mathrm{CD} 9^{+}, \mathrm{CXCR}^{+}$, and $\mathrm{CXCR} 6^{+}$, but lack the expression of CD103, presumably reflecting the lack of tight junctions in the sinusoidal endothelium. The situation in humans is slightly different since a subset of $\mathrm{CD}^{+} \mathrm{T}_{\mathrm{RM}}$ in the human liver are $\mathrm{CD}_{103}{ }^{+}$in both healthy and hepatitis $\mathrm{B}$ virusinfected individuals. In this case, the sequential exposure of the cells to IL-15 and TGF- $\beta$ induces the development of liveradapted $\mathrm{CD} 103^{+} \mathrm{CD}^{+} \mathrm{T}_{\mathrm{RM}}$ cells (233). Interestingly, mouse liver $\mathrm{CD}^{+} \mathrm{T}_{\mathrm{RM}}$ cells exhibit an amoeboid shape and migrate with a crawling action along the sinusoids, whereas circulating $\mathrm{CD}^{+} \mathrm{T}_{\mathrm{EM}}$ cells exhibit a round shape and flow rapidly in the sinusoid (232). Lymphocyte function-associated antigen 1 (LFA-1) has been found to be crucial for the patrolling behavior of liver $\mathrm{CD}^{+} \mathrm{T}_{\mathrm{RM}}$ cells in the sinusoid (234). It is also known that Kupffer cells, macrophages, and LSEC in the sinusoid constitutively express CXCL16, a CXCR6 ligand (235-237), which attracts NK cells, another resident cell population in the sinusoid (238). This suggests that liver-resident $\mathrm{CD}^{+} \mathrm{T}$ cells and NK cells share this chemokine niche (239), although competition between these populations for this niche has not been reported. Local antigen presentation is clearly important for the prolonged retention and establishment of $\mathrm{CD}^{+} \mathrm{T}_{\mathrm{RM}}$ cells in the sinusoid, as targeting antigen presentation to the hepatocytes in the presence of antigen-specific $\mathrm{CD} 8^{+} \mathrm{T}$ cells in the circulation leads to the massive accumulation of $\mathrm{CD}^{+}$ $\mathrm{T}_{\mathrm{RM}}$ cells in the sinusoid, a strategy termed as "prime and trap" (232). Since local antigen presentation in the liver can trigger the formation of tertiary immune structures known as intrahepatic myeloid cell aggregates for $\mathrm{T}$ cell population expansion (iMATE) (240), it is tempting to speculate that such follicle-like structures provide special $\mathrm{T}$ cell niches in the liver, especially for $\mathrm{CD}^{+} \mathrm{T}_{\mathrm{RM}}$ cells.

\section{Kidneys}

The kidney is a highly vascularized tissue that is crucial for filtering the blood and removing toxins from the body. Lymphocytes are relatively rare in healthy kidneys, although small numbers of resident immune cells such as DC, macrophages, and T cells can be found in the interstitium under steady-state condition $(241,242) . \mathrm{CD}^{+} \mathrm{T}_{\mathrm{RM}}$ cells can persist in extravascular renal compartments following direct (243) or regional infections with pathogens $(6,83,99,244)$, although their precise distribution is not clear (244). While the majority of renal $\mathrm{CD}^{+} \mathrm{T}_{\mathrm{RM}}$ cells express CD69, even in the absence of antigen, only small fraction of cells express CD103 $(83,243,244)$. The tissue-derived factors that influence the formation of renal $\mathrm{CD}^{+} \mathrm{T}_{\mathrm{RM}}$ cells are poorly defined. However, it has been reported that a lack of TGF- $\beta$ signaling leads to reduction in the formation of $\mathrm{CD}^{+} \mathrm{T}_{\mathrm{RM}}$ cells in the kidney (244). This has been attributed to the role of TGF- $\beta$ signaling in promoting trans-endothelial migration of effector $\mathrm{CD}^{+} \mathrm{T}$ cells by upregulating ligands for $\mathrm{E}-$ and P-selectin, including an activated form of CD43, and CXCR3 (244). IL-15 is also known to be essential for the upregulation of CD43 (245), which may explain the defective establishment of renal $\mathrm{CD}^{+} \mathrm{T}_{\mathrm{RM}}$ cells in the absence of IL-15 (99).

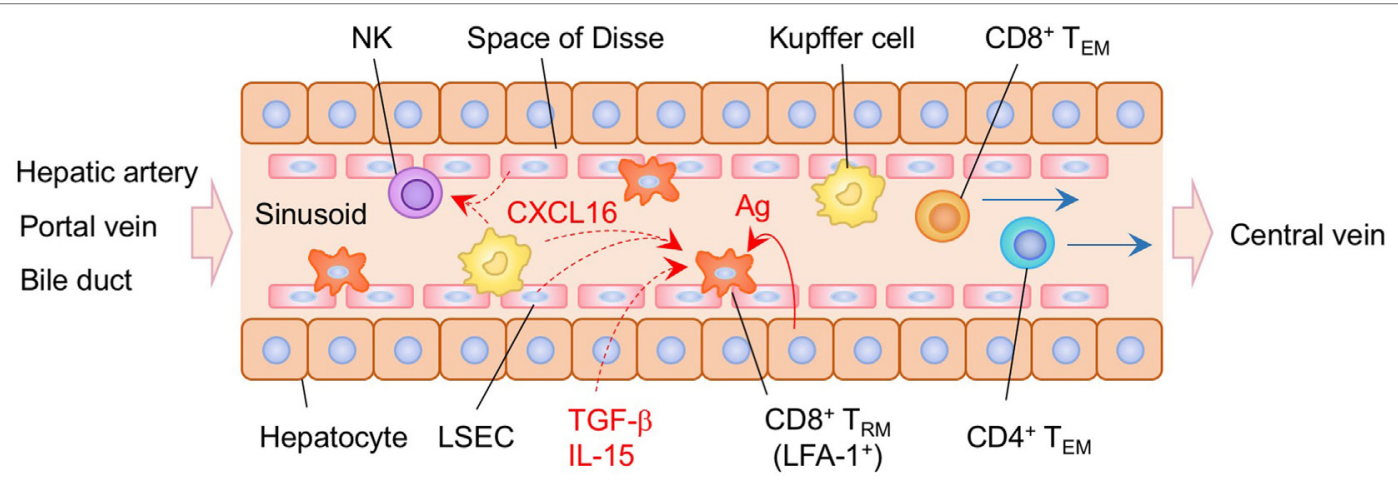

FIGURE $7 \mid T_{\text {RM }}$ niches in the in the liver. CD8 ${ }^{+} T_{R M}$ cells are localized within the sinusoid of the liver. These cells exhibit an amoeboid shape and crawling along the sinusoid dependent on the expression of lymphocyte function-associated antigen 1 (LFA-1). Antigen expressed on the hepatocytes play a key role in the establishment of CD8 ${ }^{+} \mathrm{T}_{\mathrm{RM}}$ cells in the liver sinusoid. Kupffer cells and NK cells are also resident populations in the sinusoid. CXCL16 secreted by Kupffer cells and liver sinusoidal endothelial cells (LSEC) may promote the retention of $T_{R M}$ cells and NK cells within the sinusoid. $T_{E M}$ cells are passing through the sinusoid without crawling. Orange and blue cells indicate $\mathrm{CD}^{+}$and $\mathrm{CD} 4^{+} \mathrm{T}_{\mathrm{RM}}$ cells, respectively, unless otherwise stated. A red line indicates the representative niche factor that influences the maintenance of $\mathrm{T}_{\mathrm{RM}}$ cells. Blue lines indicate the migratory route. Dashed lines indicate potential impact of niche factors. Abbreviations: Ag, antigen; $\mathrm{T}_{\mathrm{RM}}$, tissue-resident memory $\mathrm{T}$ cells; $\mathrm{T}_{\mathrm{EM}}$, effector memory $\mathrm{T}$ cells. 


\section{White Adipose Tissue (WAT)}

While $\mathrm{T}_{\mathrm{RM}}$ generally function locally to guard the vulnerable sites from reinfection, an interesting exception is the establishment of antigen-specific CD8 ${ }^{+} \mathrm{T}_{\mathrm{RM}}$ cells in the WAT (246). These cells exhibit a high turnover rate and active metabolism and can augment recall responses generated by non-lipid compartments, suggesting that the WAT functions as a reservoir of $\mathrm{T}_{\mathrm{RM}}$ cells by improving their functional capacities and longevity. Notably, WAT $\mathrm{T}_{\mathrm{RM}}$ cells also remodel the physiological function of the WAT, as reactivation of adipose $\mathrm{T}_{\mathrm{RM}}$ cells lead to a sharp decrease in lipid synthesis. This elevates the antimicrobial responses within the adipose tissues, resulting in synergic immunological crosstalk between the tissue and the $\mathrm{T}_{\mathrm{RM}}$ cells. Thus, it is of interesting to speculate that, beyond the role as the local sentinel, long-term maintenance of $\mathrm{T}_{\mathrm{RM}}$ cells may influence the homeostasis and function of each tissue, leading to both beneficial and detrimental consequences.

\section{Tumor}

It has been reported that $\mathrm{CD}^{+} \mathrm{T}$ cells with a $\mathrm{T}_{\mathrm{RM}}$ phenotypes $\left(\mathrm{CD}_{103}{ }^{+}\right.$and $\left.\mathrm{CD} 49 \mathrm{a}^{+}\right)$are present in solid tumors $(247,248)$. Large-scale transcriptome analysis has revealed that $\mathrm{CD} 8^{+}$tumor infiltrating lymphocytes (TIL) exhibit characteristics of $\mathrm{T}_{\mathrm{RM}}$ cells and it has been observed that $\mathrm{CD} 103^{+} \mathrm{CD}^{+} \mathrm{T}_{\mathrm{RM}}$ cells from neighboring peripheral tissues can infiltrate into solid tumors $(249,250)$. Runx3 expression appears to promote the infiltration of $\mathrm{CD}^{+} \mathrm{T}_{\mathrm{RM}}$ cells into tumors as Runx3-deficient $\mathrm{CD}^{+} \mathrm{T}$ cells failed to accumulate in tumors (90). As with other tissues, local microenvironmental cues promote the acquisition of $\mathrm{T}_{\mathrm{RM}}$ phenotypes of $\mathrm{CD}^{+}$that infiltrate tumor tissues (251). It is important to note, however, that CD8 ${ }^{+} \mathrm{TIL}$ with $\mathrm{T}_{\mathrm{RM}}$ characteristics (termed as $\mathrm{CD}^{+} \mathrm{T}_{\mathrm{RM}}$ TIL hereafter) are no longer true "resting" $\mathrm{T}_{\mathrm{RM}}$ cells as they are located in an effector site where cognate antigen is abundant and typically express checkpoint molecules to regulate their activity (249). This checkpoint molecule expression may be transient, or below suppressive levels, since $\mathrm{CD} 8^{+} \mathrm{T}_{\mathrm{RM}} \mathrm{TIL}$ in tumors exhibit superior anti-tumor activities and a positive prognosis has been correlated with the quality and quantity of these cells $(248-250,252-256)$. It has also been found that $\mathrm{CD}_{103}{ }^{+}$ $\mathrm{CD}^{+} \mathrm{T}_{\mathrm{RM}}$ TIL with the strongest CTL activity are located in the border area of the tumor. This contrasts with CD103 negative $\mathrm{CD}^{+} \mathrm{T}_{\mathrm{RM}}$ TIL that infiltrate the stroma of the tumor (a potentially highly immune suppressive environment), and mediate weak CTL activity (257). CD103-mediated efficient interaction of $\mathrm{CD}^{+} \mathrm{T}_{\mathrm{RM}}$ TIL with tumor cells of epithelial origin also promotes prolonged survival and enhanced CTL activity (251, 254, $258,259)$. Based on these findings, the generation of $\mathrm{CD}^{+} \mathrm{T}_{\mathrm{RM}}$ cells in neighboring tissues to the tumor is a promising strategy to confer protection against tumor growth (250, 260-263). However, this protection is limited to primary tumors, and not metastases, since $C D 8^{+} \mathrm{T}_{\mathrm{RM}}$ cells are segregated from the circulation (250).

\section{LYMPHOID ORGANS}

\section{Secondary Lymphoid Organs \\ LNs, Spleen}

The SLOs have generally been considered a transit site for $\mathrm{T}_{\mathrm{CM}}$ and $\mathrm{T}_{\mathrm{EM}}$ cells. In the case of the $\mathrm{LN}$, these cells are transiting from the high endothelial venules and afferent lymphatics, respectively, into the circulation. However, recent studies have demonstrated that there are also small numbers of memory $\mathrm{CD}^{+}$ and $\mathrm{CD}^{+} \mathrm{T}$ cells that are resident in the $\mathrm{LN}$, spleen, $\mathrm{PP}$, and tonsils without recirculation (264-268). The long-term residency of $\mathrm{T}_{\mathrm{RM}}$ cells within the SLO has been demonstrated by parabiosis or photoconversion-based cell labeling studies $(264,265$, $267,268)$. Unlike circulating memory T cells, $\mathrm{T}_{\mathrm{RM}}$ cells in the SLO share phenotypic characteristics and gene expression profiles with those in the NLT (110), including stable downregulation of $\mathrm{S}_{1} \mathrm{P}_{1}$, a key molecule for regulating T-cell egress from the LN (55). Indeed, most $\mathrm{T}_{\mathrm{RM}}$ cells in the SLO express CD69, which promotes the downregulation of $\mathrm{S}_{1} \mathrm{P}_{1}(110,264,266,268)$. Since surface expression of CD69 is generally transient, however, it is likely that repetitive antigen stimulation is required for the maintenance of CD69 expression and the retention of $\mathrm{T}_{\mathrm{RM}}$ cells in the SLO (110). In this regard, there is considerable evidence that residual antigen persists in the draining $\mathrm{LN}$ for several months after vaccination or the resolution of an acute infection and presumably facilitates the accumulation of memory $\mathrm{T}$ cells (154-156, 269-272). In addition, a recent study by Beura et al. have demonstrated that some $\mathrm{CD}^{+} \mathrm{T}_{\mathrm{RM}}$ cells in the $\mathrm{LN}$ are derived from cells that exit the NLT (273), thereby enhancing the accumulation of antigen-specific $\mathrm{CD}^{+} \mathrm{T}_{\mathrm{RM}}$ cells in the draining LN.

The distribution of $\mathrm{T}_{\mathrm{RM}}$ cells in the SLO depends on an antigen niche, as $\mathrm{T}_{\mathrm{RM}}$ cells are preferentially localized at the common antigen entry sites: the marginal zone and red pulp of the spleen and the subcapsular sinuses of the LN (264) (Figure 8). Although the maintenance of murine $\mathrm{T}_{\mathrm{RM}}$ cells in the SLO is relatively independent of IL-15, signaling via IL-15 and TGF- $\beta$ are known to transcriptionally downregulate $\mathrm{S}_{1} \mathrm{P}_{1}$ in human $\mathrm{T}$ cells. Indeed, $\mathrm{T}_{\mathrm{RM}}$ cells in the tonsils are localized specifically near the epithelial barrier where IL-15 is constitutively expressed (266). This is indicative of cytokine niche-dependent compartmentalization of $\mathrm{T}_{\mathrm{RM}}$ cells within the SLO. Since $\mathrm{T}_{\mathrm{CM}}$ cells in the SLO are central to pathogen clearance by generating massively increased numbers of secondary effector $\mathrm{T}$ cells during a recall response, it will be important to determine the functional contribution of $\mathrm{T}_{\mathrm{RM}}$ cells in the SLOs during the recall responses. It is possible that $\mathrm{T}_{\mathrm{RM}}$ cells in the SLO do not actively contribute to the recall response to avoid unnecessary competition with $\mathrm{T}_{\mathrm{CM}}$ cells, but are strategically positioned to protect the SLO from direct infection with pathogens.

\section{Primary Lymphoid Organs \\ Thymus}

Antigen-specific $\mathrm{CD} 8^{+} \mathrm{T}_{\mathrm{RM}}$ cells have also been found to persist in the thymus, a primary lymphoid organ (274). Thymic CD8 ${ }^{+} \mathrm{T}_{\mathrm{RM}}$ cells are established following infection with either thymus-tropic or non-tropic pathogens, with considerably higher numbers in the former. As with $\mathrm{T}_{\mathrm{RM}}$ cells in the peripheral tissues, thymic $\mathrm{CD}^{+} \mathrm{T}_{\mathrm{RM}}$ cells exhibit a canonical $\mathrm{T}_{\mathrm{RM}}$ phenotype (CD69 ${ }^{+}$ $\mathrm{CD}_{103^{+}}$). These cells localize predominantly in the medulla although a few cells lodge in the cortex (Figure 9). At least three mechanisms potentially explain the medullary localization of thymic $\mathrm{CD}^{+} \mathrm{T}_{\mathrm{RM}}$ cells. First, active TGF- $\beta$, which support the 


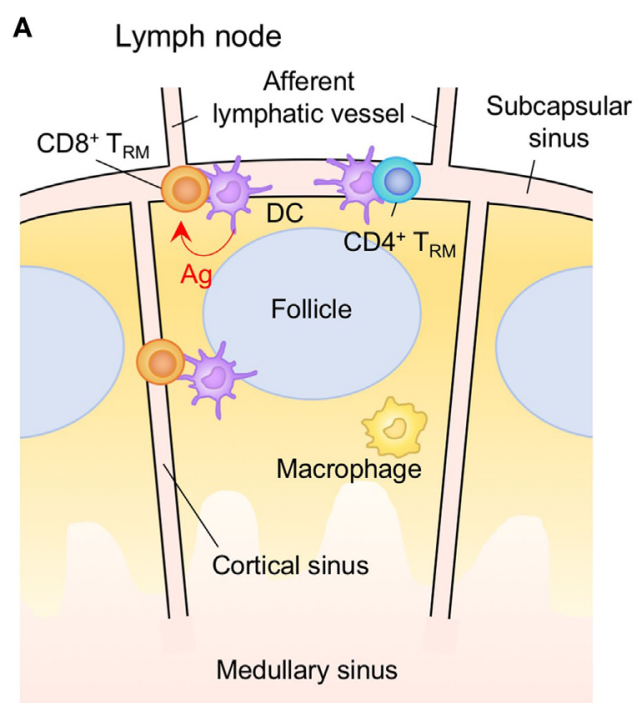

\section{B Spleen}

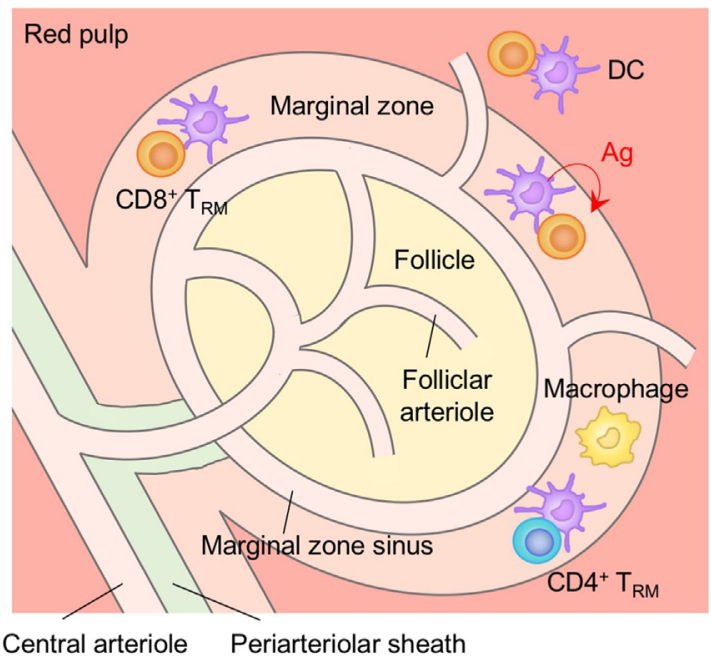

FIGURE 8 | $T_{R M}$ niches in the in the secondary lymphoid organs (SLOs). Both CD4+ and CD8 ${ }^{+} T_{R M}$ cells in the SLO are found at the common antigen entry sites, such as the subcapsular sinus in the lymph nodes (A), and the marginal zone and red pulp in the spleen (B). Retention of cells in these compartment is largely dependent on the expression of CD69 in response to antigen, although retention induced by CD69-independent mechanisms is also suspected. Orange cells indicate $\mathrm{CD}^{+} \mathrm{T}_{\mathrm{RM}}$ cells unless otherwise stated. Red lines indicate the representative niche factors that influence the maintenance of $\mathrm{T}_{\mathrm{RM}}$ cells. Abbreviations: Ag, antigen; $T_{\mathrm{RM}}$, tissue-resident memory $\mathrm{T}$ cells.

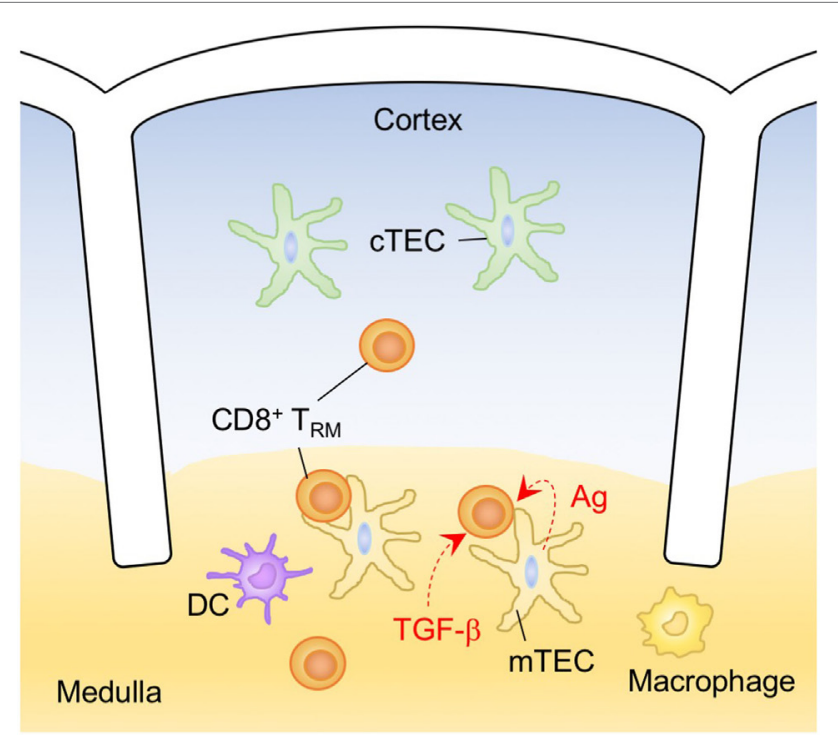

FIGURE 9 | $\mathrm{T}_{\text {RM }}$ niches in the in the thymus. CD8 ${ }^{+} \mathrm{T}_{\mathrm{RM}}$ cells are localized predominantly within the thymic medulla, although some cells are also found in the cortex. A majority of $\mathrm{CD}^{+} \mathrm{T}_{\mathrm{RM}}$ cells in the thymus express CD103 and CD69. TGF- $\beta$ is rich in the medulla, and presumably influences the CD8 ${ }^{+} \mathrm{T}$ cell expression of CD103. Since persistent presentation of foreign antigen in the thymus is uncommon, self-antigen may drive the expression of CD69 on thymic CD8 ${ }^{+} \mathrm{T}_{\mathrm{RM}}$ cells. Orange cells indicate CD8 ${ }^{+}$ $\mathrm{T}_{\mathrm{RM}}$ cells unless otherwise stated. Dashed lines indicate potential impact of niche factors. Abbreviations: Ag, antigen; cTEC, cortical thymic epithelial cell; mTEC, medullary thymic epithelial cell; $\mathrm{T}_{\mathrm{RM}}$, tissue-resident memory $\mathrm{T}$ cells. generation of thymic Treg cells and potentially upregulates $\mathrm{T}$ cell expression of $\mathrm{CD} 103$, is predominantly localized in the thymic medulla (275). Second, E-cadherin is highly expressed in all thymic epithelial cells (TEC) of both the cortex and medulla (276) and promotes the interaction of TEC with $\mathrm{CD}_{103}{ }^{+}$thymocytes (277). Third, mature thymocytes express CD69 which induces the downregulation of $\mathrm{S}_{1} \mathrm{P}_{1}$ on $\mathrm{CD}^{+} \mathrm{T}_{\mathrm{RM}}$ and blocks the departure of the cells via the medulla or cortico-medullary junction (278). The factors that induce the upregulation of CD69 on thymic $\mathrm{CD} 8^{+} \mathrm{T}_{\mathrm{RM}}$ cells have not been determined (274). Since the immune activation process strongly inhibits the migration of peripheral DC populations to the thymus to avoid unfavorable induction of acquired tolerance to the invading pathogens $(279,280)$, it is reasonable to think that thymic $\mathrm{CD}^{+} \mathrm{T}_{\mathrm{RM}}$ cells mainly function to protect the thymus, rather than contribute to the recall responses against systemic infections.

\section{Bone Marrow (BM)}

The BM is another primary lymphoid organ that facilitates the long-term maintenance of memory $\mathrm{T}$ cells by providing at least two distinct niches: a quiescence niche, that harbors a majority of quiescent memory $\mathrm{T}$ cells, and a self-renewal niche where memory $\mathrm{T}$ cells undergo homeostatic proliferation (281). Indeed, large numbers of memory $\mathrm{CD} 8^{+}$and $\mathrm{CD} 4^{+} \mathrm{T}$ cells accumulate in the BM $(282,283)$ and most of them express high levels of CD69, a hallmark of $\mathrm{T}_{\mathrm{RM}}$ cells $(164,284,285)$. TGF- $\beta$, secreted mainly by megakaryocytes in the $\mathrm{BM}$, regulates the quiescence of memory T cells (286) and CXCL12 produced by reticular stromal cells promotes their co-localization with $\mathrm{CXCR} 4^{+}$memory 
T cells (287). The reticular stromal cells, as well as myeloid cells, in the BM also provide niche factors for self-renewal such as IL-7 and IL-15 (283, 288, 289).

Recently, Di Rosa and Gebhardt have speculated that memory $\mathrm{CD}^{+} \mathrm{T}$ cells in the $\mathrm{BM}$ are a circulating population that is transiting through the $\mathrm{BM}$ niches without establishing residence (290). This is largely based on the observation that memory $\mathrm{CD}^{+} \mathrm{T}$ cells derived from the host and partner equilibrate in the BM in parabiosis experiments (65). By contrast, the deposition of memory $\mathrm{CD}^{+} \mathrm{T}$ cells in the $\mathrm{BM}$ is relatively stable, as these cells persist in the BM for a long period even after most memory CD4 ${ }^{+} \mathrm{T}$ cells disappear from the spleen and LN (283). Interestingly, $\mathrm{BM}$ memory $\mathrm{CD}^{+}{ }^{+} \mathrm{T}$ cells preferentially home back to the BM after adoptive transfer (283). A fraction of adoptively transferred splenic CD8 ${ }^{+} \mathrm{T}$ cells, particularly those with a memory phenotype, also home to the $\mathrm{BM}(282,284,291)$. These data suggest that circulating memory $\mathrm{T}$ cells have high levels of access to BM niches. High levels of access of memory T cells to the $\mathrm{BM}$ niches could also explain the low detection of $\mathrm{T}_{\mathrm{RM}}$ cells in the parabiosis experiments. More analyses are required for precise characterization of $\mathrm{T}_{\mathrm{RM}}$ cells in the $\mathrm{BM}$.

\section{CONCLUDING REMARKS}

The regulation, generation, and maintenance of $\mathrm{T}_{\mathrm{RM}}$ cells depends on two primary cell-extrinsic factors: (i) local signals that enable microenvironmental adaptation of T cells in each tissue and (ii) the availability of tissue-specific anatomical niches. Non-immune cells as well as immune cell populations resident in each microenvironment provide these niche factors. Once established, $\mathrm{T}_{\mathrm{RM}}$ cells function locally to guard the vulnerable sites from reinfection. Hence, a deep understanding the comprehensive picture of $\mathrm{T}_{\mathrm{RM}}$ niches is required for the development of tissue-targeted vaccination strategies to effectively generate $T_{R M}$ cells in each tissue. For example, "prime and pull" is a potential vaccination strategy for the skin and FRT, where $\mathrm{T}_{\mathrm{RM}}$ cells can utilize niches that are originally occupied by other resident cells $(37,127)$. In sharp contrast, this strategy does not work for the lung due to the absence of preformed niches for $\mathrm{T}_{\mathrm{RM}}$ cells to displace $(134,158)$. The creation of de novo niches in the lung by "prime and pull plus cognate antigen" partly resolves this problem $(5,134,158)$. Antigen-niches also play a role in the establishment of $\mathrm{T}_{\mathrm{RM}}$ cells in the vascularized tissues of the liver, a strategy referred to as "prime and trap" (232).

\section{REFERENCES}

1. Iijima N, Iwasaki A. Tissue instruction for migration and retention of TRM cells. Trends Immunol (2015) 36(9):556-64. doi:10.1016/j.it.2015.07.002

2. Kaech SM, Cui W. Transcriptional control of effector and memory CD8+ T cell differentiation. Nat Rev Immunol (2012) 12(11):749-61. doi:10.1038/ nri3307

3. Kim TS, Gorski SA, Hahn S, Murphy KM, Braciale TJ. Distinct dendritic cell subsets dictate the fate decision between effector and memory CD8(+) $\mathrm{T}$ cell differentiation by a CD24-dependent mechanism. Immunity (2014) 40(3):400-13. doi:10.1016/j.immuni.2014.02.004

4. Iborra S, Martinez-Lopez M, Khouili SC, Enamorado M, Cueto FJ, CondeGarrosa R, et al. Optimal generation of tissue-resident but not circulating
The description of $\mathrm{T}_{\mathrm{RM}}$ niches in this review is based primarily on findings from mouse studies with occasional reference to work in humans. It is important to note, however, that the characteristics of $\mathrm{T}_{\mathrm{RM}}$ cells in these species can vary. For example, the $\mathrm{T}_{\mathrm{RM}}$ signature in humans is primarily defined by $\mathrm{CD}^{+} 9^{+}$expression (292), while CD69 expression is insufficient to infer tissue residence in mice $(6,273)$. Furthermore, a key transcription factor Hobit that instructs tissue residency is highly expressed by murine $\mathrm{T}_{\mathrm{RM}}$ cells (62), while its expression is relatively low in human $\mathrm{T}_{\mathrm{RM}}$ cells (292-294). These, and other, species differences in $\mathrm{T}_{\mathrm{RM}}$ indicate that many more studies in humans will be necessary for the development of effective vaccines in the clinic.

In summary, the factors regulating the formation of $T_{R M}$ cells in each tissue and each species are far more complex than originally thought, and numerous hurdles exist in generating and maintaining $\mathrm{T}_{\mathrm{RM}}$ cells in each tissue in terms of the efficacy, safety, and longevity. There is still much to learn.

\section{AUTHOR CONTRIBUTIONS}

ST participated in the concept, wrote the manuscript, and developed the figures.

\section{ACKNOWLEDGMENTS}

We thank Drs. Makoto Kurachi, Norifumi Iijima, Hiroyuki Taniyama, Katsuro Higiwara, Fumitaka Sato, Takeshi Shimaoka, Kensuke Takada, and Koji Tokoyoda for discussions, and Dr. David L. Woodland for editing the manuscript.

\section{FUNDING}

This work is supported by Grant-in-Aid for Young Scientists (A) 24689043, and Grant-in-Aid for Scientific Research (C) 16K08850 from the Ministry of Education, Culture, Sports, Science and Technology of Japan, and grants from Takeda Science Foundation, Daiichi-Sankyo Foundation of Life Science, Uehara Memorial Foundation, Kanae Foundation for the Promotion of Medical Science, The Waksman Foundation of Japan, Kato Memorial Bioscience Foundation, Mochida Memorial Foundation for Medical and Pharmaceutical Research, Life Science Foundation of Japan, Japan Foundation for Pediatric Research, The Naito Foundation, and SENSHIN Medical Research Foundation.

memory $\mathrm{T}$ cells during viral infection requires crosspriming by DNGR-1+ dendritic cells. Immunity (2016) 45(4):847-60. doi:10.1016/j.immuni.2016. 08.019

5. Takamura S. Persistence in temporary lung niches: a survival strategy of lung-resident memory CD8(+) T cells. Viral Immunol (2017) 30(6):438-50. doi:10.1089/vim.2017.0016

6. Steinert EM, Schenkel JM, Fraser KA, Beura LK, Manlove LS, Igyarto BZ, et al. Quantifying memory CD8 T cells reveals regionalization of immunosurveillance. Cell (2015) 161(4):737-49. doi:10.1016/j.cell.2015.03.031

7. Sallusto F, Geginat J, Lanzavecchia A. Central memory and effector memory T cell subsets: function, generation, and maintenance. Annu Rev Immunol (2004) 22:745-63. doi:10.1146/annurev.immunol.22.012703. 104702 
8. Woodland DL, Kohlmeier JE. Migration, maintenance and recall of memory T cells in peripheral tissues. Nat Rev Immunol (2009) 9(3):153-61. doi:10.1038/nri2496

9. Chen K, Wang JM, Yuan R, Yi X, Li L, Gong W, et al. Tissue-resident dendritic cells and diseases involving dendritic cell malfunction. Int Immunopharmacol (2016) 34:1-15. doi:10.1016/j.intimp.2016.02.007

10. Nielsen MM, Witherden DA, Havran WL. gammadelta T cells in homeostasis and host defence of epithelial barrier tissues. Nat Rev Immunol (2017) 17(12):733-45. doi:10.1038/nri.2017.101

11. Klose CS, Artis D. Innate lymphoid cells as regulators of immunity, inflammation and tissue homeostasis. Nat Immunol (2016) 17(7):765-74. doi:10.1038/ ni.3489

12. Mowat AM, Scott CL, Bain CC. Barrier-tissue macrophages: functional adaptation to environmental challenges. Nat Med (2017) 23(11):1258-70. doi:10.1038/nm.4430

13. Bergsbaken T, Bevan MJ, Fink PJ. Local inflammatory cues regulate differentiation and persistence of CD8(+) tissue-resident memory T cells. Cell Rep (2017) 19(1):114-24. doi:10.1016/j.celrep.2017.03.031

14. Collins N, Jiang X, Zaid A, Macleod BL, Li J, Park CO, et al. Skin CD4(+) memory $\mathrm{T}$ cells exhibit combined cluster-mediated retention and equilibration with the circulation. Nat Commun (2016) 7:11514. doi:10.1038/ ncomms 11514

15. Iijima N, Iwasaki A. T cell memory. A local macrophage chemokine network sustains protective tissue-resident memory CD4 T cells. Science (2014) 346(6205):93-8. doi:10.1126/science. 1257530

16. Zaid A, Mackay LK, Rahimpour A, Braun A, Veldhoen M, Carbone FR, et al. Persistence of skin-resident memory $\mathrm{T}$ cells within an epidermal niche. Proc Natl Acad Sci U S A (2014) 111(14):5307-12. doi:10.1073/pnas. 1322292111

17. Mueller SN, Mackay LK. Tissue-resident memory T cells: local specialists in immune defence. Nat Rev Immunol (2016) 16(2):79-89. doi:10.1038/nri. 2015.3

18. Tay SS, Roediger B, Tong PL, Tikoo S, Weninger W. The skin-resident immune network. Curr Dermatol Rep (2014) 3:13-22. doi:10.1007/s13671-0130063-9

19. Nestle FO, Di Meglio P, Qin JZ, Nickoloff BJ. Skin immune sentinels in health and disease. Nat Rev Immunol (2009) 9(10):679-91. doi:10.1038/nri2622

20. Mueller SN, Zaid A, Carbone FR. Tissue-resident T cells: dynamic players in skin immunity. Front Immunol (2014) 5:332. doi:10.3389/fimmu.2014. 00332

21. Heath WR, Carbone FR. The skin-resident and migratory immune system in steady state and memory: innate lymphocytes, dendritic cells and T cells. Nat Immunol (2013) 14(10):978-85. doi:10.1038/ni.2680

22. Solanas G, Benitah SA. Regenerating the skin: a task for the heterogeneous stem cell pool and surrounding niche. Nat Rev Mol Cell Biol (2013) 14(11): 737-48. doi:10.1038/nrm3675

23. Adachi T, Kobayashi T, Sugihara E, Yamada T, Ikuta K, Pittaluga S, et al. Hair follicle-derived IL-7 and IL-15 mediate skin-resident memory T cell homeostasis and lymphoma. Nat Med (2015) 21(11):1272-9. doi:10.1038/ nm.3962

24. Kaplan DH. Ontogeny and function of murine epidermal Langerhans cells. Nat Immunol (2017) 18(10):1068-75. doi:10.1038/ni.3815

25. Mohammed J, Beura LK, Bobr A, Astry B, Chicoine B, Kashem SW, et al. Stromal cells control the epithelial residence of DCs and memory $\mathrm{T}$ cells by regulated activation of TGF-beta. Nat Immunol (2016) 17(4):414-21. doi:10.1038/ni.3396

26. Zhang L, Yang SH, Sharrocks AD. Rev7/MAD2B links c-Jun N-terminal protein kinase pathway signaling to activation of the transcription factor Elk-1. Mol Cell Biol (2007) 27(8):2861-9. doi:10.1128/MCB.02276-06

27. Seneschal J, Clark RA, Gehad A, Baecher-Allan CM, Kupper TS. Human epidermal Langerhans cells maintain immune homeostasis in skin by activating skin resident regulatory T cells. Immunity (2012) 36(5):873-84. doi:10.1016/j.immuni.2012.03.018

28. Macleod AS, Havran WL. Functions of skin-resident gammadelta T cells. Cell Mol Life Sci (2011) 68(14):2399-408. doi:10.1007/s00018-011-0702-x

29. Sumaria N, Roediger B, Ng LG, Qin J, Pinto R, Cavanagh LL, et al. Cutaneous immunosurveillance by self-renewing dermal gammadelta $\mathrm{T}$ cells. J Exp Med (2011) 208(3):505-18. doi:10.1084/jem.20101824
30. De Creus A, Van Beneden K, Stevenaert F, Debacker V, Plum J, Leclercq G. Developmental and functional defects of thymic and epidermal $\mathrm{V}$ gamma 3 cells in IL-15-deficient and IFN regulatory factor-1-deficient mice. J Immunol (2002) 168(12):6486-93. doi:10.4049/jimmunol.168.12.6486

31. Maki K, Sunaga S, Komagata Y, Kodaira Y, Mabuchi A, Karasuyama H, et al. Interleukin 7 receptor-deficient mice lack gammadelta $\mathrm{T}$ cells. Proc Natl Acad Sci U S A (1996) 93(14):7172-7. doi:10.1073/pnas.93.14.7172

32. Kadow S, Jux B, Zahner SP, Wingerath B, Chmill S, Clausen BE, et al. Aryl hydrocarbon receptor is critical for homeostasis of invariant gammadelta $\mathrm{T}$ cells in the murine epidermis. J Immunol (2011) 187(6):3104-10. doi:10.4049/jimmunol.1100912

33. Esser C, Bargen I, Weighardt H, Haarmann-Stemmann T, Krutmann J. Functions of the aryl hydrocarbon receptor in the skin. Semin Immunopathol (2013) 35(6):677-91. doi:10.1007/s00281-013-0394-4

34. Borkowski TA, Letterio JJ, Farr AG, Udey MC. A role for endogenous transforming growth factor beta 1 in Langerhans cell biology: the skin of transforming growth factor beta 1 null mice is devoid of epidermal Langerhans cells. J Exp Med (1996) 184(6):2417-22. doi:10.1084/jem.184.6.2417

35. Gebhardt T, Whitney PG, Zaid A, Mackay LK, Brooks AG, Heath WR, et al. Different patterns of peripheral migration by memory CD4+ and CD8+ T cells. Nature (2011) 477(7363):216-9. doi:10.1038/nature10339

36. Gebhardt T, Wakim LM, Eidsmo L, Reading PC, Heath WR, Carbone FR Memory $\mathrm{T}$ cells in nonlymphoid tissue that provide enhanced local immunity during infection with herpes simplex virus. Nat Immunol (2009) 10(5): 524-30. doi:10.1038/ni.1718

37. Mackay LK, Stock AT, Ma JZ, Jones CM, Kent SJ, Mueller SN, et al. Long-lived epithelial immunity by tissue-resident memory T (TRM) cells in the absence of persisting local antigen presentation. Proc Natl Acad Sci U S A (2012) 109(18):7037-42. doi:10.1073/pnas.1202288109

38. Jiang X, Clark RA, Liu L, Wagers AJ, Fuhlbrigge RC, Kupper TS. Skin infection generates non-migratory memory $\mathrm{CD} 8+\mathrm{T}(\mathrm{RM})$ cells providing global skin immunity. Nature (2012) 483(7388):227-31. doi:10.1038/ nature10851

39. Davies B, Prier JE, Jones CM, Gebhardt T, Carbone FR, Mackay LK. Cutting edge: tissue-resident memory $\mathrm{T}$ cells generated by multiple immunizations or localized deposition provide enhanced immunity. JImmunol (2017) 198(6):2233-7. doi:10.4049/jimmunol.1601367

40. Zhu J, Peng T, Johnston C, Phasouk K, Kask AS, Klock A, et al. Immune surveillance by $\mathrm{CD}$ 8alphaalpha+ skin-resident $\mathrm{T}$ cells in human herpes virus infection. Nature (2013) 497(7450):494-7. doi:10.1038/nature12110

41. Morales J, Homey B, Vicari AP, Hudak S, Oldham E, Hedrick J, et al. CTACK, a skin-associated chemokine that preferentially attracts skinhoming memory T cells. Proc Natl Acad Sci U S A (1999) 96(25):14470-5. doi:10.1073/pnas.96.25.14470

42. Zaid A, Hor JL, Christo SN, Groom JR, Heath WR, Mackay LK, et al. Chemokine receptor-dependent control of skin tissue-resident memory T cell formation. J Immunol (2017) 199(7):2451-9. doi:10.4049/jimmunol. 1700571

43. Mackay LK, Rahimpour A, Ma JZ, Collins N, Stock AT, Hafon ML, et al. The developmental pathway for CD103(+)CD8+ tissue-resident memory T cells of skin. Nat Immunol (2013) 14(12):1294-301. doi:10.1038/ ni. 2744

44. Pauls K, Schon M, Kubitza RC, Homey B, Wiesenborn A, Lehmann P, et al. Role of integrin alphaE(CD103)beta7 for tissue-specific epidermal localization of CD8+ T lymphocytes. J Invest Dermatol (2001) 117(3):569-75. doi:10.1046/j.0022-202x.2001.01481.x

45. Mackay LK, Wynne-Jones E, Freestone D, Pellicci DG, Mielke LA, Newman DM, et al. T-box transcription factors combine with the cytokines TGF-beta and IL-15 to control tissue-resident memory T cell fate. Immunity (2015) 43(6):1101-11. doi:10.1016/j.immuni.2015.11.008

46. McCully ML, Ladell K, Hakobyan S, Mansel RE, Price DA, Moser B. Epidermis instructs skin homing receptor expression in human T cells. Blood (2012) 120(23):4591-8. doi:10.1182/blood-2012-05-433037

47. McCully ML, Ladell K, Andrews R, Jones RE, Miners KL, Roger L, et al. CCR8 expression defines tissue-resident memory $\mathrm{T}$ cells in human skin. J Immunol (2018) 200(5):1639-50. doi:10.4049/jimmunol.1701377

48. Ariotti S, Beltman JB, Chodaczek G, Hoekstra ME, van Beek AE, GomezEerland R, et al. Tissue-resident memory CD8+ T cells continuously patrol 
skin epithelia to quickly recognize local antigen. Proc Natl Acad Sci U S A (2012) 109(48):19739-44. doi:10.1073/pnas.1208927109

49. Park SL, Zaid A, Hor JL, Christo SN, Prier JE, Davies B, et al. Local proliferation maintains a stable pool of tissue-resident memory $\mathrm{T}$ cells after antiviral recall responses. Nat Immunol (2018) 19(2):183-91. doi:10.1038/ s41590-017-0027-5

50. Pan Y, Tian T, Park CO, Lofftus SY, Mei S, Liu X, et al. Survival of tissueresident memory $\mathrm{T}$ cells requires exogenous lipid uptake and metabolism. Nature (2017) 543(7644):252-6. doi:10.1038/nature21379

51. Clark RA, Chong B, Mirchandani N, Brinster NK, Yamanaka K, Dowgiert RK, et al. The vast majority of CLA+ T cells are resident in normal skin. J Immunol (2006) 176(7):4431-9. doi:10.4049/jimmunol.176.7.4431

52. Glennie ND, Yeramilli VA, Beiting DP, Volk SW, Weaver CT, Scott P. Skin-resident memory CD4+ T cells enhance protection against Leishmania major infection. J Exp Med (2015) 212(9):1405-14. doi:10.1084/jem. 20142101

53. Ono S, Kabashima K. Novel insights into the role of immune cells in skin and inducible skin-associated lymphoid tissue (iSALT). Allergo J Int (2015) 24:170-9. doi:10.1007/s40629-015-0065-1

54. Khan TN, Mooster JL, Kilgore AM, Osborn JF, Nolz JC. Local antigen in nonlymphoid tissue promotes resident memory CD8+ T cell formation during viral infection. J Exp Med (2016) 213(6):951-66. doi:10.1084/jem. 20151855

55. Cyster JG, Schwab SR. Sphingosine-1-phosphate and lymphocyte egress from lymphoid organs. Annu Rev Immunol (2012) 30:69-94. doi:10.1146/ annurev-immunol-020711-075011

56. Shiow LR, Rosen DB, Brdickova N, Xu Y, An J, Lanier LL, et al. CD69 acts downstream of interferon-alpha/beta to inhibit S1P1 and lymphocyte egress from lymphoid organs. Nature (2006) 440(7083):540-4. doi:10.1038/ nature 04606

57. Mackay LK, Braun A, Macleod BL, Collins N, Tebartz C, Bedoui S, et al. Cutting edge: CD69 interference with sphingosine-1-phosphate receptor function regulates peripheral T cell retention. J Immunol (2015) 194(5):2059-63. doi:10.4049/jimmunol.1402256

58. Muschaweckh A, Buchholz VR, Fellenzer A, Hessel C, Konig PA, Tao S, et al. Antigen-dependent competition shapes the local repertoire of tissue-resident memory CD8+ T cells. J Exp Med (2016) 213(13):3075-86. doi:10.1084/ jem.20160888

59. Cheuk S, Schlums H, Gallais Serezal I, Martini E, Chiang SC, Marquardt N, et al. CD49a expression defines tissue-resident $\mathrm{CD} 8(+) \mathrm{T}$ cells poised for cytotoxic function in human skin. Immunity (2017) 46(2):287-300. doi:10.1016/j.immuni.2017.01.009

60. Malik BT, Byrne KT, Vella JL, Zhang P, Shabaneh TB, Steinberg SM, et al. Resident memory $\mathrm{T}$ cells in the skin mediate durable immunity to melanoma. Sci Immunol (2017) 2(10):eaam6346. doi:10.1126/sciimmunol.aam6346

61. Skon CN, Lee JY, Anderson KG, Masopust D, Hogquist KA, Jameson SC. Transcriptional downregulation of S1pr1 is required for the establishment of resident memory CD8+ T cells. Nat Immunol (2013) 14(12):1285-93. doi:10.1038/ni.2745

62. Mackay LK, Minnich M, Kragten NA, Liao Y, Nota B, Seillet C, et al. Hobit and Blimp1 instruct a universal transcriptional program of tissue residency in lymphocytes. Science (2016) 352(6284):459-63. doi:10.1126/science. aad 2035

63. Mackay LK, Kallies A. Transcriptional regulation of tissue-resident lymphocytes. Trends Immunol (2017) 38(2):94-103. doi:10.1016/j.it.2016.11.004

64. Mowat AM, Agace WW. Regional specialization within the intestinal immune system. Nat Rev Immunol (2014) 14(10):667-85. doi:10.1038/nri3738

65. Klonowski KD, Williams KJ, Marzo AL, Blair DA, Lingenheld EG, Lefrancois L. Dynamics of blood-borne CD8 memory T cell migration in vivo. Immunity (2004) 20(5):551-62. doi:10.1016/S1074-7613(04)00103-7

66. Olivares-Villagomez D, Van Kaer L. Intestinal intraepithelial lymphocytes: sentinels of the mucosal barrier. Trends Immunol (2018) 39(4):264-75. doi:10.1016/j.it.2017.11.003

67. Cheroutre H, Lambolez F, Mucida D. The light and dark sides of intestinal intraepithelial lymphocytes. Nat Rev Immunol (2011) 11(7):445-56. doi: $10.1038 /$ nri3007

68. Maloy KJ, Mowat AM, Zamoyska R, Crispe IN. Phenotypic heterogeneity of intraepithelial $\mathrm{T}$ lymphocytes from mouse small intestine. Immunology (1991) 72(4):555-62.
69. Mota-Santos T, Masmoudi H, Voegtle D, Freitas A, Coutinho A, Cazenave PA. Divergency in the specificity of the induction and maintenance of neonatal suppression. Eur J Immunol (1990) 20(8):1717-21. doi:10.1002/eji. 1830200814

70. Bergsbaken T, Bevan MJ. Proinflammatory microenvironments within the intestine regulate the differentiation of tissue-resident CD8(+) T cells responding to infection. Nat Immunol (2015) 16(4):406-14. doi:10.1038/ ni.3108

71. Sheridan BS, Pham QM, Lee YT, Cauley LS, Puddington L, Lefrancois L. Oral infection drives a distinct population of intestinal resident memory $\mathrm{CD} 8(+) \mathrm{T}$ cells with enhanced protective function. Immunity (2014) 40(5):747-57. doi:10.1016/j.immuni.2014.03.007

72. Tomov VT, Palko O, Lau CW, Pattekar A, Sun Y, Tacheva R, et al. Differentiation and protective capacity of virus-specific $\mathrm{CD} 8(+) \mathrm{T}$ cells suggest murine norovirus persistence in an immune-privileged enteric niche. Immunity (2017) 47(4):723-38.e5. doi:10.1016/j.immuni.2017.09.017

73. Romagnoli PA, Fu HH, Qiu Z, Khairallah C, Pham QM, Puddington L, et al. Differentiation of distinct long-lived memory CD4 T cells in intestinal tissues after oral Listeria monocytogenes infection. Mucosal Immunol (2017) 10(2):520-30. doi:10.1038/mi.2016.66

74. Sheridan BS, Romagnoli PA, Pham QM, Fu HH, Alonzo F III, Schubert WD, et al. gammadelta $\mathrm{T}$ cells exhibit multifunctional and protective memory in intestinal tissues. Immunity (2013) 39(1):184-95. doi:10.1016/j.immuni. 2013.06.015

75. Iwata M, Hirakiyama A, Eshima Y, Kagechika H, Kato C, Song SY. Retinoic acid imprints gut-homing specificity on T cells. Immunity (2004) 21(4):527-38. doi:10.1016/j.immuni.2004.08.011

76. Bargatze RF, Jutila MA, Butcher EC. Distinct roles of L-selectin and integrins alpha 4 beta 7 and LFA-1 in lymphocyte homing to Peyer's patchHEV in situ: the multistep model confirmed and refined. Immunity (1995) 3(1):99-108. doi:10.1016/1074-7613(95)90162-0

77. Hamann A, Andrew DP, Jablonski-Westrich D, Holzmann B, Butcher EC. Role of alpha 4-integrins in lymphocyte homing to mucosal tissues in vivo. J Immunol (1994) 152(7):3282-93.

78. Svensson M, Marsal J, Ericsson A, Carramolino L, Broden T, Marquez G, et al. CCL25 mediates the localization of recently activated CD8alphabeta(+) lymphocytes to the small-intestinal mucosa. JClin Invest (2002) 110(8): 1113-21. doi:10.1172/JCI0215988

79. Wurbel MA, Malissen M, Guy-Grand D, Malissen B, Campbell JJ. Impaired accumulation of antigen-specific CD8 lymphocytes in chemokine CCL25deficient intestinal epithelium and lamina propria. JImmunol (2007) 178(12):7598-606. doi:10.4049/jimmunol.178.12.7598

80. Kunkel EJ, Campbell JJ, Haraldsen G, Pan J, Boisvert J, Roberts AI, et al. Lymphocyte CC chemokine receptor 9 and epithelial thymus-expressed chemokine (TECK) expression distinguish the small intestinal immune compartment: epithelial expression of tissue-specific chemokines as an organizing principle in regional immunity. J Exp Med (2000) 192(5):761-8. doi:10.1084/jem.192.5.761

81. Koyama SY, Podolsky DK. Differential expression of transforming growth factors alpha and beta in rat intestinal epithelial cells. J Clin Invest (1989) 83(5):1768-73. doi:10.1172/JCI114080

82. Yang L, Qiu CX, Ludlow A, Ferguson MW, Brunner G. Active transforming growth factor-beta in wound repair: determination using a new assay. Am J Pathol (1999) 154(1):105-11. doi:10.1016/S0002-9440(10)65256-X

83. Casey KA, Fraser KA, Schenkel JM, Moran A, Abt MC, Beura LK, et al. Antigen-independent differentiation and maintenance of effector-like resident memory T cells in tissues. J Immunol (2012) 188(10):4866-75. doi:10.4049/ jimmunol.1200402

84. Schon MP, Arya A, Murphy EA, Adams CM, Strauch UG, Agace WW, et al. Mucosal T lymphocyte numbers are selectively reduced in integrin alpha $\mathrm{E}$ (CD103)-deficient mice. J Immunol (1999) 162(11):6641-9.

85. Zhang N, Bevan MJ. Transforming growth factor-beta signaling controls the formation and maintenance of gut-resident memory $\mathrm{T}$ cells by regulating migration and retention. Immunity (2013) 39(4):687-96. doi:10.1016/j. immuni.2013.08.019

86. Konkel JE, Maruyama T, Carpenter AC, Xiong Y, Zamarron BF, Hall BE, et al. Control of the development of CD8alphaalpha+ intestinal intraepithelial lymphocytes by TGF-beta. Nat Immunol (2011) 12(4):312-9. doi:10.1038/ ni. 1997 
87. Grueter B, Petter M, Egawa T, Laule-Kilian K, Aldrian CJ, Wuerch A, et al. Runx3 regulates integrin alpha E/CD103 and CD4 expression during development of CD4-/CD8+ T cells. J Immunol (2005) 175(3):1694-705. doi:10.4049/jimmunol.175.3.1694

88. Reis BS, Rogoz A, Costa-Pinto FA, Taniuchi I, Mucida D. Mutual expression of the transcription factors Runx3 and ThPOK regulates intestinal CD4(+) T cell immunity. Nat Immunol (2013) 14(3):271-80. doi:10.1038/ni.2518

89. Shi MJ, Stavnezer J. CBF alpha3 (AML2) is induced by TGF-beta1 to bind and activate the mouse germline Ig alpha promoter. JImmunol (1998) 161(12):6751-60.

90. Milner JJ, Toma C, Yu B, Zhang K, Omilusik K, Phan AT, et al. Runx3 programs CD8(+) $\mathrm{T}$ cell residency in non-lymphoid tissues and tumours. Nature (2017) 552(7684):253-7. doi:10.1038/nature24993

91. Huang Y, Park Y, Wang-Zhu Y, Larange A, Arens R, Bernardo I, et al. Mucosal memory CD8(+) T cells are selected in the periphery by an MHC class I molecule. Nat Immunol (2011) 12(11):1086-95. doi:10.1038/ni.2106

92. Masopust D, Choo D, Vezys V, Wherry EJ, Duraiswamy J, Akondy R, et al. Dynamic $\mathrm{T}$ cell migration program provides resident memory within intestinal epithelium. J Exp Med (2010) 207(3):553-64. doi:10.1084/jem. 20090858

93. Sowell RT, Goldufsky JW, Rogozinska M, Quiles Z, Cao Y, Castillo EF, et al. IL-15 complexes induce migration of resting memory CD8 $\mathrm{T}$ cells into mucosal tissues. J Immunol (2017) 199(7):2536-46. doi:10.4049/jimmunol. 1501638

94. Tian Y, Cox MA, Kahan SM, Ingram JT, Bakshi RK, Zajac AJ. A contextdependent role for IL-21 in modulating the differentiation, distribution, and abundance of effector and memory CD8 T cell subsets. J Immunol (2016) 196(5):2153-66. doi:10.4049/jimmunol.1401236

95. Yu Q, Tang C, Xun S, Yajima T, Takeda K, Yoshikai Y. MyD88-dependent signaling for IL-15 production plays an important role in maintenance of CD8 alpha alpha TCR alpha beta and TCR gamma delta intestinal intraepithelial lymphocytes. J Immunol (2006) 176(10):6180-5. doi:10.4049/ jimmunol.176.10.6180

96. Nakazato K, Yamada H, Yajima T, Kagimoto Y, Kuwano H, Yoshikai Y. Enforced expression of Bcl-2 partially restores cell numbers but not functions of TCRgammadelta intestinal intraepithelial T lymphocytes in IL15-deficient mice. J Immunol (2007) 178(2):757-64. doi:10.4049/jimmunol. 178.2.757

97. Lai YG, Hou MS, Hsu YW, Chang CL, Liou YH, Tsai MH, et al. IL-15 does not affect IEL development in the thymus but regulates homeostasis of putative precursors and mature CD8 alpha alpha+ IELs in the intestine. J Immunol (2008) 180(6):3757-65. doi:10.4049/jimmunol.180.6.3757

98. Ma LJ, Acero LF, Zal T, Schluns KS. Trans-presentation of IL-15 by intestinal epithelial cells drives development of CD8alphaalpha IELs. J Immunol (2009) 183(2):1044-54. doi:10.4049/jimmunol.0900420

99. Schenkel JM, Fraser KA, Casey KA, Beura LK, Pauken KE, Vezys V, et al. IL-15-independent maintenance of tissue-resident and boosted effector memory CD8 T cells. J Immunol (2016) 196(9):3920-6. doi:10.4049/jimmunol. 1502337

100. Agace WW, McCoy KD. Regionalized development and maintenance of the intestinal adaptive immune landscape. Immunity (2017) 46(4):532-48. doi:10.1016/j.immuni.2017.04.004

101. Nguyen LP, Pan J, Dinh TT, Hadeiba H, O'Hara E III, Ebtikar A, et al. Role and species-specific expression of colon T cell homing receptor GPR15 in colitis. Nat Immunol (2015) 16(2):207-13. doi:10.1038/ni.3079

102. Kumamoto Y, Iwasaki A. Unique features of antiviral immune system of the vaginal mucosa. Curr Opin Immunol (2012) 24(4):411-6. doi:10.1016/j. coi.2012.05.006

103. Iwasaki A. Antiviral immune responses in the genital tract: clues for vaccines. Nat Rev Immunol (2010) 10(10):699-711. doi:10.1038/nri2836

104. Shin H, Iwasaki A. Tissue-resident memory T cells. Immunol Rev (2013) 255(1):165-81. doi:10.1111/imr.12087

105. Roy A, Matzuk MM. Reproductive tract function and dysfunction in women. Nat Rev Endocrinol (2011) 7(9):517-25. doi:10.1038/nrendo.2011.79

106. Lee SK, Kim CJ, Kim DJ, Kang JH. Immune cells in the female reproductive tract. Immune Netw (2015) 15(1):16-26. doi:10.4110/in.2015.15.1.16

107. Wira CR, Rodriguez-Garcia M, Patel MV. The role of sex hormones in immune protection of the female reproductive tract. Nat Rev Immunol (2015) 15(4):217-30. doi:10.1038/nri3819
108. Johnson RM, Brunham RC. Tissue-resident T cells as the central paradigm of chlamydia immunity. Infect Immun (2016) 84(4):868-73. doi:10.1128/ IAI.01378-15

109. Wira CR, Fahey JV, Rodriguez-Garcia M, Shen Z, Patel MV. Regulation of mucosal immunity in the female reproductive tract: the role of sex hormones in immune protection against sexually transmitted pathogens. Am J Reprod Immunol (2014) 72(2):236-58. doi:10.1111/aji.12252

110. Beura LK, Mitchell JS, Thompson EA, Schenkel JM, Mohammed J, Wijeyesinghe $\mathrm{S}$, et al. Intravital mucosal imaging of $\mathrm{CD} 8(+)$ resident memory T cells shows tissue-autonomous recall responses that amplify secondary memory. Nat Immunol (2018) 19(2):173-82. doi:10.1038/s41590017-0029-3

111. Miller MJ, Wei SH, Parker I, Cahalan MD. Two-photon imaging of lymphocyte motility and antigen response in intact lymph node. Science (2002) 296(5574):1869-73. doi:10.1126/science.1070051

112. Ariotti S, Hogenbirk MA, Dijkgraaf FE, Visser LL, Hoekstra ME, Song JY, et al. T cell memory. Skin-resident memory CD8(+) T cells trigger a state of tissue-wide pathogen alert. Science (2014) 346(6205):101-5. doi:10.1126/ science. 1254803

113. Stary G, Olive A, Radovic-Moreno AF, Gondek D, Alvarez D, Basto PA, et al. VACCINES. A mucosal vaccine against Chlamydia trachomatis generates two waves of protective memory T cells. Science (2015) 348(6241) aaa8205. doi:10.1126/science.aaa8205

114. Davila SJ, Olive AJ, Starnbach MN. Integrin alpha4betal is necessary for CD4+ T cell-mediated protection against genital Chlamydia trachomatis infection. J Immunol (2014) 192(9):4284-93. doi:10.4049/jimmunol. 1303238

115. Hawkins RA, Rank RG, Kelly KA. Expression of mucosal homing receptor alpha4beta7 is associated with enhanced migration to the Chlamydiainfected murine genital mucosa in vivo. Infect Immun (2000) 68(10):5587-94 doi:10.1128/IAI.68.10.5587-5594.2000

116. Gondek DC, Olive AJ, Stary G, Starnbach MN. CD4+ T cells are necessary and sufficient to confer protection against Chlamydia trachomatis infection in the murine upper genital tract. J Immunol (2012) 189(5):2441-9. doi:10.4049/jimmunol.1103032

117. Morrison SG, Morrison RP. In situ analysis of the evolution of the primary immune response in murine Chlamydia trachomatis genital tract infection. Infect Immun (2000) 68(5):2870-9. doi:10.1128/IAI.68.5.28702879.2000

118. Morrison SG, Su H, Caldwell HD, Morrison RP. Immunity to murine Chlamydia trachomatis genital tract reinfection involves B cells and CD4(+) $\mathrm{T}$ cells but not CD8(+) T cells. Infect Immun (2000) 68(12):6979-87. doi:10.1128/IAI.68.12.6979-6987.2000

119. Johnson RM, Yu H, Strank NO, Karunakaran K, Zhu Y, Brunham RC. B cell presentation of chlamydia antigen selects out protective CD4gamma13 $\mathrm{T}$ cells: implications for genital tract tissue-resident memory lymphocyte clusters. Infect Immun (2018) 86(2):e614-7. doi:10.1128/IAI.00614-17

120. Ijima N, Linehan MM, Zamora M, Butkus D, Dunn R, Kehry MR, et al. Dendritic cells and B cells maximize mucosal Th1 memory response to herpes simplex virus. J Exp Med (2008) 205(13):3041-52. doi:10.1084/ jem.20082039

121. Freeman EE, Weiss HA, Glynn JR, Cross PL, Whitworth JA, Hayes RJ. Herpes simplex virus 2 infection increases HIV acquisition in men and women: systematic review and meta-analysis of longitudinal studies. AIDS (2006) 20(1):73-83. doi:10.1097/01.aids.0000198081.09337.a7

122. Zhu J, Hladik F, Woodward A, Klock A, Peng T, Johnston C, et al. Persistence of HIV-1 receptor-positive cells after HSV-2 reactivation is a potential mechanism for increased HIV-1 acquisition. Nat Med (2009) 15(8):886-92. doi: $10.1038 / \mathrm{nm} .2006$

123. Suvas PK, Dech HM, Sambira F, Zeng J, Onami TM. Systemic and mucosal infection program protective memory CD8 T cells in the vaginal mucosa. J Immunol (2007) 179(12):8122-7. doi:10.4049/jimmunol.179.12.8122

124. Sato A, Suwanto A, Okabe M, Sato S, Nochi T, Imai T, et al. Vaginal memory $\mathrm{T}$ cells induced by intranasal vaccination are critical for protective T cell recruitment and prevention of genital HSV-2 disease. J Virol (2014) 88(23):13699-708. doi:10.1128/JVI.02279-14

125. Tan HX, Wheatley AK, Esterbauer R, Jegaskanda S, Glass JJ, Masopust D, et al. Induction of vaginal-resident HIV-specific CD8 T cells with mucosal primeboost immunization. Mucosal Immunol (2017). doi:10.1038/mi.2017.89 
126. Nakanishi Y, Lu B, Gerard C, Iwasaki A. CD8(+) T lymphocyte mobilization to virus-infected tissue requires CD4(+) T-cell help. Nature (2009) 462(7272):510-3. doi:10.1038/nature08511

127. Shin $\mathrm{H}$, Iwasaki A. A vaccine strategy that protects against genital herpes by establishing local memory T cells. Nature (2012) 491(7424):463-7. doi:10.1038/nature11522

128. Wu HY, Nguyen HH, Russell MW. Nasal lymphoid tissue (NALT) as a mucosal immune inductive site. Scand J Immunol (1997) 46(5):506-13. doi:10.1046/j.1365-3083.1997.d01-159.x

129. Kiyono H, Fukuyama S. NALT- versus Peyer's-patch-mediated mucosal immunity. Nat Rev Immunol (2004) 4(9):699-710. doi:10.1038/nri1439

130. Pizzolla A, Wang Z, Groom JR, Kedzierska K, Brooks AG, Reading PC, et al. Nasal-associated lymphoid tissues (NALTs) support the recall but not priming of influenza virus-specific cytotoxic T cells. Proc Natl Acad Sci U S A (2017) 114(20):5225-30. doi:10.1073/pnas.1620194114

131. Pizzolla A, Nguyen THO, Smith JM, Brooks AG, Kedzieska K, Heath WR, et al. Resident memory CD8(+) T cells in the upper respiratory tract prevent pulmonary influenza virus infection. Sci Immunol (2017) 2(12):eaam6970. doi:10.1126/sciimmunol.aam6970

132. Jahnsen FL, Farstad IN, Aanesen JP, Brandtzaeg P. Phenotypic distribution of T cells in human nasal mucosa differs from that in the gut. Am J Respir Cell Mol Biol (1998) 18(3):392-401. doi:10.1165/ajrcmb.18.3.2995

133. Wakim LM, Woodward-Davis A, Bevan MJ. Memory T cells persisting within the brain after local infection show functional adaptations to their tissue of residence. Proc Natl Acad Sci U S A (2010) 107(42):17872-9. doi:10.1073/ pnas. 1010201107

134. Takamura S, Yagi H, Hakata Y, Motozono C, McMaster SR, Masumoto T, et al. Specific niches for lung-resident memory CD8+ T cells at the site of tissue regeneration enable CD69-independent maintenance. J Exp Med (2016) 213(13):3057-73. doi:10.1084/jem.20160938

135. Hu Y, Lee YT, Kaech SM, Garvy B, Cauley LS. Smad4 promotes differentiation of effector and circulating memory CD8 T cells but is dispensable for tissue-resident memory CD8 T cells. J Immunol (2015) 194(5):2407-14. doi:10.4049/jimmunol.1402369

136. Pawankar RU, Okuda M, Suzuki K, Okumura K, Ra C. Phenotypic and molecular characteristics of nasal mucosal gamma delta $\mathrm{T}$ cells in allergic and infectious rhinitis. Am J Respir Crit Care Med (1996) 153(5):1655-65. doi:10.1164/ajrccm.153.5.8630617

137. Lambert Emo K, Hyun YM, Reilly E, Barilla C, Gerber S, Fowell D, et al. Live imaging of influenza infection of the trachea reveals dynamic regulation of CD8+ T cell motility by antigen. PLoS Pathog (2016) 12(9):e1005881. doi:10.1371/journal.ppat.1005881

138. Anderson KG, Sung H, Skon CN, Lefrancois L, Deisinger A, Vezys V, et al. Cutting edge: intravascular staining redefines lung CD8 $\mathrm{T}$ cell responses. J Immunol (2012) 189(6):2702-6. doi:10.4049/jimmunol.1201682

139. Hogan RJ, Cauley LS, Ely KH, Cookenham T, Roberts AD, Brennan JW, et al. Long-term maintenance of virus-specific effector memory CD8+ $\mathrm{T}$ cells in the lung airways depends on proliferation. J Immunol (2002) 169(9):4976-81. doi:10.4049/jimmunol.169.9.4976

140. Slutter B, Pewe LL, Kaech SM, Harty JT. Lung airway-surveilling CXCR3(hi) memory CD8(+) T cells are critical for protection against influenza A virus. Immunity (2013) 39(5):939-48. doi:10.1016/j.immuni.2013.09.013

141. Kohlmeier JE, Miller SC, Woodland DL. Cutting edge: antigen is not required for the activation and maintenance of virus-specific memory CD8+ $\mathrm{T}$ cells in the lung airways. J Immunol (2007) 178(8):4721-5. doi:10.4049/ jimmunol.178.8.4721

142. Kadoki M, Patil A, Thaiss CC, Brooks DJ, Pandey S, Deep D, et al. Organismlevel analysis of vaccination reveals networks of protection across tissues. Cell (2017) 171(2):398-413.e21. doi:10.1016/j.cell.2017.08.024

143. Liu L, Zhong Q, Tian T, Dubin K, Athale SK, Kupper TS. Epidermal injury and infection during poxvirus immunization is crucial for the generation of highly protective T cell-mediated immunity. Nat Med (2010) 16(2):224-7. doi: $10.1038 / \mathrm{nm} .2078$

144. Ely KH, Cookenham T, Roberts AD, Woodland DL. Memory T cell populations in the lung airways are maintained by continual recruitment. J Immunol (2006) 176(1):537-43. doi:10.4049/jimmunol.176.1.537

145. Iwasaki A, Foxman EF, Molony RD. Early local immune defences in the respiratory tract. Nat Rev Immunol (2017) 17(1):7-20. doi:10.1038/nri.2016.117
146. Abboud G, Desai P, Dastmalchi F, Stanfield J, Tahiliani V, Hutchinson TE, et al. Tissue-specific programming of memory CD8 T cell subsets impacts protection against lethal respiratory virus infection. J Exp Med (2016) 213 (13):2897-911. doi:10.1084/jem.20160167

147. Ray SJ, Franki SN, Pierce RH, Dimitrova S, Koteliansky V, Sprague AG, et al. The collagen binding alphalbetal integrin VLA-1 regulates CD8 T cell-mediated immune protection against heterologous influenza infection. Immunity (2004) 20(2):167-79. doi:10.1016/S1074-7613(04)00021-4

148. Wakim LM, Smith J, Caminschi I, Lahoud MH, Villadangos JA. Antibodytargeted vaccination to lung dendritic cells generates tissue-resident memory CD8 $\mathrm{T}$ cells that are highly protective against influenza virus infection. Mucosal Immunol (2015) 8(5):1060-71. doi:10.1038/mi.2014.133

149. Wu T, Hu Y, Lee YT, Bouchard KR, Benechet A, Khanna K, et al. Lung-resident memory CD8 T cells (TRM) are indispensable for optimal cross-protection against pulmonary virus infection. J Leukoc Biol (2014) 95(2):215-24. doi:10.1189/jlb.0313180

150. Yoshizawa A, Bi K, Keskin DB, Zhang G, Reinhold B, Reinherz EL. TCR-pMHC encounter differentially regulates transcriptomes of tissueresident CD8 T cells. Eur J Immunol (2018) 48(1):128-50. doi:10.1002/eji. 201747174

151. Verbist KC, Cole CJ, Field MB, Klonowski KD. A role for IL-15 in the migration of effector CD8 T cells to the lung airways following influenza infection. J Immunol (2011) 186(1):174-82. doi:10.4049/jimmunol.1002613

152. Verbist KC, Field MB, Klonowski KD. Cutting edge: IL-15-independent maintenance of mucosally generated memory CD8 T cells. J Immunol (2011) 186(12):6667-71. doi:10.4049/jimmunol.1004022

153. Kohlmeier JE, Woodland DL. Immunity to respiratory viruses. Annu Rev Immunol (2009) 27:61-82. doi:10.1146/annurev.immunol.021908.132625

154. Zammit DJ, Turner DL, Klonowski KD, Lefrancois L, Cauley LS. Residual antigen presentation after influenza virus infection affects CD8 T cell activation and migration. Immunity (2006) 24(4):439-49. doi:10.1016/j.immuni. 2006.01.015

155. Kim TS, Hufford MM, Sun J, Fu YX, Braciale TJ. Antigen persistence and the control of local $\mathrm{T}$ cell memory by migrant respiratory dendritic cells after acute virus infection. J Exp Med (2010) 207(6):1161-72. doi:10.1084/ jem.20092017

156. Takamura S, Roberts AD, Jelley-Gibbs DM, Wittmer ST, Kohlmeier JE, Woodland DL. The route of priming influences the ability of respiratory virus-specific memory CD8+ T cells to be activated by residual antigen. J Exp Med (2010) 207(6):1153-60. doi:10.1084/jem.20090283

157. Slütter B, Van Braeckel-Budimir N, Abboud G, Varga SM, Salek-Ardakani S, Harty JT. Dynamics of influenza-induced lung-resident memory T cells underlie waning heterosubtypic immunity. Sci Immunol (2017) 2(7):eaag2031. doi:10.1126/sciimmunol.aag2031

158. McMaster SR, Wein AN, Dunbar PR, Hayward SL, Cartwright EK, Denning TL, et al. Pulmonary antigen encounter regulates the establishment of tissueresident CD8 memory T cells in the lung airways and parenchyma. Mucosal Immunol (2018). doi:10.1038/s41385-018-0003-X

159. Wakim LM, Gupta N, Mintern JD, Villadangos JA. Enhanced survival of lung tissue-resident memory CD8(+) T cells during infection with influenza virus due to selective expression of IFITM3. Nat Immunol (2013) 14(3):238-45. doi:10.1038/ni.2525

160. Hombrink P, Helbig C, Backer RA, Piet B, Oja AE, Stark R, et al. Programs for the persistence, vigilance and control of human CD8+ lung-resident memory T cells. Nat Immunol (2016) 17(12):1467-78. doi:10.1038/ni.3589

161. Zhou AC, Wagar LE, Wortzman ME, Watts TH. Intrinsic 4-1BB signals are indispensable for the establishment of an influenza-specific tissue-resident memory CD8 T-cell population in the lung. Mucosal Immunol (2017) 10(5):1294-309. doi:10.1038/mi.2016.124

162. Hondowicz BD, An D, Schenkel JM, Kim KS, Steach HR, Krishnamurty AT, et al. Interleukin-2-dependent allergen-specific tissue-resident memory cells drive asthma. Immunity (2016) 44(1):155-66. doi:10.1016/j.immuni. 2015.11.004

163. Turner DL, Bickham KL, Thome JJ, Kim CY, D’Ovidio F, Wherry EJ, et al. Lung niches for the generation and maintenance of tissue-resident memory T cells. Mucosal Immunol (2014) 7(3):501-10. doi:10.1038/mi.2013.67

164. Shinoda K, Tokoyoda K, Hanazawa A, Hayashizaki K, Zehentmeier S, Hosokawa $\mathrm{H}$, et al. Type II membrane protein CD69 regulates the formation 
of resting T-helper memory. Proc Natl Acad Sci US A (2012) 109(19):7409-14. doi:10.1073/pnas.1118539109

165. Hwang JY, Randall TD, Silva-Sanchez A. Inducible bronchus-associated lymphoid tissue: taming inflammation in the lung. Front Immunol (2016) 7:258. doi:10.3389/fimmu.2016.00258

166. McKinstry KK, Strutt TM, Bautista B, Zhang W, Kuang Y, Cooper AM, et al. Effector CD4 T-cell transition to memory requires late cognate interactions that induce autocrine IL-2. Nat Commun (2014) 5:5377. doi:10.1038/ ncomms6377

167. Bautista BL, Devarajan P, McKinstry KK, Strutt TM, Vong AM, Jones MC, et al. Short-lived antigen recognition but not viral infection at a defined checkpoint programs effector $\mathrm{CD} 4 \mathrm{~T}$ cells to become protective memory. J Immunol (2016) 197(10):3936-49. doi:10.4049/jimmunol.1600838

168. Thomas PG, Brown SA, Yue W, So J, Webby RJ, Doherty PC. An unexpected antibody response to an engineered influenza virus modifies CD8+ T cell responses. Proc Natl Acad Sci U S A (2006) 103(8):2764-9. doi:10.1073/ pnas.0511185103

169. Strutt TM, Dhume K, Finn CM, Hwang JH, Castonguay C, Swain SL, et al. IL-15 supports the generation of protective lung-resident memory CD4 T cells. Mucosal Immunol (2017). doi:10.1038/mi.2017.101

170. Oja AE, Piet B, Helbig C, Stark R, van der Zwan D, Blaauwgeers H, et al. Trigger-happy resident memory CD4(+) T cells inhabit the human lungs. Mucosal Immunol (2017). doi:10.1038/mi.2017.94

171. Amano O, Mizobe K, Bando Y, Sakiyama K. Anatomy and histology of rodent and human major salivary glands: overview of the Japan salivary gland society-sponsored workshop. Acta Histochem Cytochem (2012) 45(5):241-50. doi:10.1267/ahc.12013

172. Mega J, McGhee JR, Kiyono H. Cytokine- and Ig-producing T cells in mucosal effector tissues: analysis of IL-5- and IFN-gamma-producing $\mathrm{T}$ cells, $\mathrm{T}$ cell receptor expression, and IgA plasma cells from mouse salivary gland-associated tissues. J Immunol (1992) 148(7):2030-9.

173. Grewal JS, Pilgrim MJ, Grewal S, Kasman L, Werner P, Bruorton ME, et al. Salivary glands act as mucosal inductive sites via the formation of ectopic germinal centers after site-restricted MCMV infection. FASEB J (2011) 25 (5):1680-96. doi:10.1096/fj.10-174656

174. Lu X, Pinto AK, Kelly AM, Cho KS, Hill AB. Murine cytomegalovirus interference with antigen presentation contributes to the inability of CD8 T cells to control virus in the salivary gland. J Virol (2006) 80(8):4200-2. doi:10.1128/JVI.80.8.4200-4202.2006

175. Lucin P, Pavic I, Polic B, Jonjic S, Koszinowski UH. Gamma interferondependent clearance of cytomegalovirus infection in salivary glands. J Virol (1992) 66(4):1977-84.

176. Walton SM, Mandaric S, Torti N, Zimmermann A, Hengel H, Oxenius A. Absence of cross-presenting cells in the salivary gland and viral immune evasion confine cytomegalovirus immune control to effector CD4 T cells. PLoS Pathog (2011) 7(8):e1002214. doi:10.1371/journal.ppat.1002214

177. Campbell AE, Cavanaugh VJ, Slater JS. The salivary glands as a privileged site of cytomegalovirus immune evasion and persistence. Med Microbiol Immunol (2008) 197(2):205-13. doi:10.1007/s00430-008-0077-2

178. Jonjic S, Mutter W, Weiland F, Reddehase MJ, Koszinowski UH. Site-restricted persistent cytomegalovirus infection after selective long-term depletion of CD4+ T lymphocytes. J Exp Med (1989) 169(4):1199-212. doi:10.1084/ jem.169.4.1199

179. Thom JT, Weber TC, Walton SM, Torti N, Oxenius A. The salivary gland acts as a sink for tissue-resident memory $\mathrm{CD} 8(+) \mathrm{T}$ cells, facilitating protection from local cytomegalovirus infection. Cell Rep (2015) 13(6):1125-36. doi:10.1016/j.celrep.2015.09.082

180. Smith CJ, Caldeira-Dantas S, Turula H, Snyder CM. Murine CMV infection induces the continuous production of mucosal resident $\mathrm{T}$ cells. Cell Rep (2015) 13(6):1137-48. doi:10.1016/j.celrep.2015.09.076

181. Thom JT, Oxenius A. Tissue-resident memory T cells in cytomegalovirus infection. Curr Opin Virol (2016) 16:63-9. doi:10.1016/j.coviro.2016.01.014

182. Woyciechowski S, Hofmann M, Pircher H. alpha4 betal integrin promotes accumulation of tissue-resident memory $\mathrm{CD} 8(+) \mathrm{T}$ cells in salivary glands. Eur J Immunol (2017) 47(2):244-50. doi:10.1002/eji.201646722

183. Hofmann M, Pircher H. E-cadherin promotes accumulation of a unique memory CD8 T-cell population in murine salivary glands. Proc Natl Acad Sci U S A (2011) 108(40):16741-6. doi:10.1073/pnas.1107200108
184. O'Hara GA, Welten SP, Klenerman P, Arens R. Memory T cell inflation: understanding cause and effect. Trends Immunol (2012) 33(2):84-90. doi:10.1016/j.it.2011.11.005

185. Snyder CM, Cho KS, Bonnett EL, van Dommelen S, Shellam GR, Hill AB. Memory inflation during chronic viral infection is maintained by continuous production of short-lived, functional T cells. Immunity (2008) 29(4):650-9. doi:10.1016/j.immuni.2008.07.017

186. Torti N, Walton SM, Brocker T, Rulicke T, Oxenius A. Non-hematopoietic cells in lymph nodes drive memory CD8 $\mathrm{T}$ cell inflation during murine cytomegalovirus infection. PLoS Pathog (2011) 7(10):e1002313. doi:10.1371/ journal.ppat. 1002313

187. Snyder CM, Allan JE, Bonnett EL, Doom CM, Hill AB. Cross-presentation of a spread-defective MCMV is sufficient to prime the majority of virusspecific CD8+ T cells. PLoS One (2010) 5(3):e9681. doi:10.1371/journal. pone. 0009681

188. Caldeira-Dantas S, Furmanak T, Smith C, Quinn M, Teos LY, Ertel A, et al. The chemokine receptor CXCR3 promotes $\mathrm{CD} 8(+) \mathrm{T}$ cell accumulation in uninfected salivary glands but is not necessary after murine cytomegalovirus infection. J Immunol (2018) 200(3):1133-45. doi:10.4049/jimmunol. 1701272

189. Smolders J, Remmerswaal EB, Schuurman KG, Melief J, van Eden CG, van Lier RA, et al. Characteristics of differentiated CD8(+) and CD4 (+) $\mathrm{T}$ cells present in the human brain. Acta Neuropathol (2013) 126(4):525-35. doi:10.1007/s00401-013-1155-0

190. Russo MV, McGavern DB. Immune surveillance of the CNS following infection and injury. Trends Immunol (2015) 36(10):637-50. doi:10.1016/j. it.2015.08.002

191. Ellwardt E, Walsh JT, Kipnis J, Zipp F. Understanding the role of T cells in CNS homeostasis. Trends Immunol (2016) 37(2):154-65. doi:10.1016/j. it.2015.12.008

192. Schwartz M, Baruch K. The resolution of neuroinflammation in neurodegeneration: leukocyte recruitment via the choroid plexus. EMBO J (2014) 33(1):7-22. doi:10.1002/embj.201386609

193. Ransohoff RM, Engelhardt B. The anatomical and cellular basis of immune surveillance in the central nervous system. Nat Rev Immunol (2012) 12(9):623-35. doi:10.1038/nri3265

194. Aspelund A, Antila S, Proulx ST, Karlsen TV, Karaman S, Detmar M, et al. A dural lymphatic vascular system that drains brain interstitial fluid and macromolecules. J Exp Med (2015) 212(7):991-9. doi:10.1084/jem. 20142290

195. Louveau A, Smirnov I, Keyes TJ, Eccles JD, Rouhani SJ, Peske JD, et al. Structural and functional features of central nervous system lymphatic vessels. Nature (2015) 523(7560):337-41. doi:10.1038/nature14432

196. Prinz M, Priller J. The role of peripheral immune cells in the CNS in steady state and disease. Nat Neurosci (2017) 20(2):136-44. doi:10.1038/nn.4475

197. Korn T, Kallies A. T cell responses in the central nervous system. Nat Rev Immunol (2017) 17(3):179-94. doi:10.1038/nri.2016.144

198. Swanson PA II, McGavern DB. Viral diseases of the central nervous system. Curr Opin Virol (2015) 11:44-54. doi:10.1016/j.coviro.2014.12.009

199. Kang SS, Herz J, Kim JV, Nayak D, Stewart-Hutchinson P, Dustin ML, et al. Migration of cytotoxic lymphocytes in cell cycle permits local MHC I-dependent control of division at sites of viral infection. J Exp Med (2011) 208(4):747-59. doi:10.1084/jem.20101295

200. Wilson EH, Harris TH, Mrass P, John B, Tait ED, Wu GF, et al. Behavior of parasite-specific effector CD8+ $\mathrm{T}$ cells in the brain and visualization of a kinesis-associated system of reticular fibers. Immunity (2009) 30(2):300-11. doi:10.1016/j.immuni.2008.12.013

201. Bartholomaus I, Kawakami N, Odoardi F, Schlager C, Miljkovic D, Ellwart JW, et al. Effector $\mathrm{T}$ cell interactions with meningeal vascular structures in nascent autoimmune CNS lesions. Nature (2009) 462(7269):94-8. doi:10.1038/ nature 08478

202. Wilson EH, Weninger W, Hunter CA. Trafficking of immune cells in the central nervous system. J Clin Invest (2010) 120(5):1368-79. doi:10.1172/ JCI41911

203. McCandless EE, Zhang B, Diamond MS, Klein RS. CXCR4 antagonism increases $\mathrm{T}$ cell trafficking in the central nervous system and improves survival from West Nile virus encephalitis. Proc Natl Acad Sci U S A (2008) 105(32):11270-5. doi:10.1073/pnas.0800898105 
204. Cruz-Orengo L, Holman DW, Dorsey D, Zhou L, Zhang P, Wright M, et al. CXCR7 influences leukocyte entry into the CNS parenchyma by controlling abluminal CXCL12 abundance during autoimmunity. JExp Med (2011) 208(2):327-39. doi:10.1084/jem.20102010

205. Zhang B, Chan YK, Lu B, Diamond MS, Klein RS. CXCR3 mediates region-specific antiviral $\mathrm{T}$ cell trafficking within the central nervous system during West Nile virus encephalitis. JImmunol (2008) 180(4):2641-9. doi:10.4049/jimmunol.180.4.2641

206. Dufour JH, Dziejman M, Liu MT, Leung JH, Lane TE, Luster AD. IFNgamma-inducible protein 10 (IP-10; CXCL10)-deficient mice reveal a role for IP-10 in effector T cell generation and trafficking. JImmunol (2002) 168(7):3195-204. doi:10.4049/jimmunol.168.7.3195

207. Glass WG, Lim JK, Cholera R, Pletnev AG, Gao JL, Murphy PM. Chemokine receptor CCR5 promotes leukocyte trafficking to the brain and survival in West Nile virus infection. J Exp Med (2005) 202(8):1087-98. doi:10.1084/ jem.20042530

208. Glass WG, McDermott DH, Lim JK, Lekhong S, Yu SF, Frank WA, et al. CCR5 deficiency increases risk of symptomatic West Nile virus infection. J Exp Med (2006) 203(1):35-40. doi:10.1084/jem.20051970

209. Muller M, Carter SL, Hofer MJ, Manders P, Getts DR, Getts MT, et al. CXCR3 signaling reduces the severity of experimental autoimmune encephalomyelitis by controlling the parenchymal distribution of effector and regulatory T cells in the central nervous system. J Immunol (2007) 179(5): 2774-86. doi:10.4049/jimmunol.179.5.2774

210. Koyuncu OO, Hogue IB, Enquist LW. Virus infections in the nervous system. Cell Host Microbe (2013) 13(4):379-93. doi:10.1016/j.chom.2013.03.010

211. Steinbach K, Vincenti I, Kreutzfeldt M, Page N, Muschaweckh A, Wagner I, et al. Brain-resident memory $\mathrm{T}$ cells represent an autonomous cytotoxic barrier to viral infection. J Exp Med (2016) 213(8):1571-87. doi:10.1084/ jem.20151916

212. Wakim LM, Woodward-Davis A, Liu R, Hu Y, Villadangos J, Smyth G, et al. The molecular signature of tissue resident memory CD8 T cells isolated from the brain. J Immunol (2012) 189(7):3462-71. doi:10.4049/jimmunol. 1201305

213. Shwetank, Abdelsamed HA, Frost EL, Schmitz HM, Mockus TE, Youngblood BA, et al. Maintenance of PD-1 on brain-resident memory CD8 T cells is antigen independent. Immunol Cell Biol (2017) 95(10):953-9. doi:10.1038/ icb. 2017.62

214. Landrith TA, Sureshchandra S, Rivera A, Jang JC, Rais M, Nair MG, et al. CD103(+) CD8 T cells in the toxoplasma-infected brain exhibit a tissue-resident memory transcriptional profile. Front Immunol (2017) 8:335. doi:10.3389/fimmu.2017.00335

215. Graham JB, Da Costa A, Lund JM. Regulatory T cells shape the resident memory T cell response to virus infection in the tissues. J Immunol (2014) 192(2):683-90. doi:10.4049/jimmunol.1202153

216. Prasad S, Hu S, Sheng WS, Singh A, Lokensgard JR. Tregs modulate lymphocyte proliferation, activation, and resident-memory T-cell accumulation within the brain during MCMV infection. PLoS One (2015) 10(12):e0145457. doi:10.1371/journal.pone.0145457

217. Shimamura K, Takeichi M. Local and transient expression of E-cadherin involved in mouse embryonic brain morphogenesis. Development (1992) 116(4):1011-9.

218. Blattman JN, Wherry EJ, Ha SJ, van der Most RG, Ahmed R. Impact of epitope escape on PD-1 expression and CD8 T-cell exhaustion during chronic infection. J Virol (2009) 83(9):4386-94. doi:10.1128/JVI.02524-08

219. Pavelko KD, Bell MP, Harrington SM, Dong H. B7-H1 influences the accumulation of virus-specific tissue resident memory $\mathrm{T}$ cells in the central nervous system. Front Immunol (2017) 8:1532. doi:10.3389/fimmu. 2017.01532

220. Prasad S, Hu S, Sheng WS, Chauhan P, Singh A, Lokensgard JR. The PD-1: PD-L1 pathway promotes development of brain-resident memory T cells following acute viral encephalitis. J Neuroinflammation (2017) 14(1):82. doi:10.1186/s12974-017-0860-3

221. Patsoukis N, Bardhan K, Chatterjee P, Sari D, Liu B, Bell LN, et al. PD-1 alters T-cell metabolic reprogramming by inhibiting glycolysis and promoting lipolysis and fatty acid oxidation. Nat Commun (2015) 6:6692. doi:10.1038/ ncomms 7692

222. van der Windt GJ, Everts B, Chang CH, Curtis JD, Freitas TC, Amiel E, et al. Mitochondrial respiratory capacity is a critical regulator of $\mathrm{CD} 8+$
T cell memory development. Immunity (2012) 36(1):68-78. doi:10.1016/j. immuni.2011.12.007

223. Schachtele SJ, Hu S, Sheng WS, Mutnal MB, Lokensgard JR. Glial cells suppress postencephalitic CD8+ T lymphocytes through PD-L1. Glia (2014) 62(10):1582-94. doi:10.1002/glia.22701

224. Phares TW, Ramakrishna C, Parra GI, Epstein A, Chen L, Atkinson R, et al. Target-dependent B7-H1 regulation contributes to clearance of central nervous system infection and dampens morbidity. J Immunol (2009) 182(9):5430-8. doi:10.4049/jimmunol.0803557

225. Phares TW, Stohlman SA, Hinton DR, Atkinson R, Bergmann CC. Enhanced antiviral $\mathrm{T}$ cell function in the absence of B7-H1 is insufficient to prevent persistence but exacerbates axonal bystander damage during viral encephalomyelitis. J Immunol (2010) 185(9):5607-18. doi:10.4049/ jimmunol.1001984

226. Jin YH, Hou W, Kang HS, Koh CS, Kim BS. The role of interleukin-6 in the expression of PD-1 and PDL-1 on central nervous system cells following infection with Theiler's murine encephalomyelitis virus. J Virol (2013) 87(21):11538-51. doi:10.1128/JVI.01967-13

227. Latchman YE, Liang SC, Wu Y, Chernova T, Sobel RA, Klemm M, et al. PD-L1-deficient mice show that PD-L1 on T cells, antigen-presenting cells, and host tissues negatively regulates T cells. Proc Natl Acad Sci U S A (2004) 101(29):10691-6. doi:10.1073/pnas.0307252101

228. Ely KH, Roberts AD, Woodland DL. Cutting edge: effector memory $\mathrm{CD} 8+\mathrm{T}$ cells in the lung airways retain the potential to mediate recall responses. J Immunol (2003) 171(7):3338-42. doi:10.4049/jimmunol.171. 7.3338

229. Kubes P, Jenne C. Immune responses in the liver. Annu Rev Immunol (2018) 36:247-77. doi:10.1146/annurev-immunol-051116-052415

230. Oda M, Yokomori H, Han JY. Regulatory mechanisms of hepatic microcirculation. Clin Hemorheol Microcirc (2003) 29(3-4):167-82.

231. Guidotti LG, Inverso D, Sironi L, Di Lucia P, Fioravanti J, Ganzer L, et al. Immunosurveillance of the liver by intravascular effector CD8(+) T cells. Cell (2015) 161(3):486-500. doi:10.1016/j.cell.2015.03.005

232. Fernandez-Ruiz D, Ng WY, Holz LE, Ma JZ, Zaid A, Wong YC, et al. Liver-resident memory $\mathrm{CD} 8(+) \mathrm{T}$ cells form a front-line defense against malaria liver-stage infection. Immunity (2016) 45(4):889-902. doi:10.1016/j. immuni.2016.08.011

233. Pallett LJ, Davies J, Colbeck EJ, Robertson F, Hansi N, Easom NJW, et al. IL-2(high) tissue-resident T cells in the human liver: sentinels for hepatotropic infection. J Exp Med (2017) 214(6):1567-80. doi:10.1084/jem. 20162115

234. McNamara HA, Cai Y, Wagle MV, Sontani Y, Roots CM, Miosge LA, et al. Up-regulation of LFA-1 allows liver-resident memory $\mathrm{T}$ cells to patrol and remain in the hepatic sinusoids. Sci Immunol (2017) 2(9):eaaj1996. doi:10.1126/sciimmunol.aaj1996

235. Wehr A, Baeck C, Heymann F, Niemietz PM, Hammerich L, Martin C, et al. Chemokine receptor CXCR6-dependent hepatic NK T Cell accumulation promotes inflammation and liver fibrosis. J Immunol (2013) 190(10):5226-36. doi:10.4049/jimmunol.1202909

236. Geissmann F, Cameron TO, Sidobre S, Manlongat N, Kronenberg M, Briskin MJ, et al. Intravascular immune surveillance by CXCR6+ NKT cells patrolling liver sinusoids. PLoS Biol (2005) 3(4):e113. doi:10.1371/journal. pbio.0030113

237. Shimaoka T, Seino K, Kume N, Minami M, Nishime C, Suematsu M, et al. Critical role for CXC chemokine ligand 16 (SR-PSOX) in Th1 response mediated by NKT cells. J Immunol (2007) 179(12):8172-9. doi:10.4049/ jimmunol.179.12.8172

238. Hudspeth K, Donadon M, Cimino M, Pontarini E, Tentorio P, Preti M, et al. Human liver-resident CD56(bright)/CD16(neg) NK cells are retained within hepatic sinusoids via the engagement of CCR5 and CXCR6 pathways. J Autoimmun (2016) 66:40-50. doi:10.1016/j.jaut.2015.08.011

239. Tse SW, Radtke AJ, Espinosa DA, Cockburn IA, Zavala F. The chemokine receptor CXCR6 is required for the maintenance of liver memory CD8(+) T cells specific for infectious pathogens. J Infect Dis (2014) 210(9):1508-16. doi:10.1093/infdis/jiu281

240. Huang LR, Wohlleber D, Reisinger F, Jenne CN, Cheng RL, Abdullah Z, et al. Intrahepatic myeloid-cell aggregates enable local proliferation of CD8(+) T cells and successful immunotherapy against chronic viral liver infection. Nat Immunol (2013) 14(6):574-83. doi:10.1038/ni.2573 
241. Ascon DB, Ascon M, Satpute S, Lopez-Briones S, Racusen L, Colvin RB, et al. Normal mouse kidneys contain activated and CD3+CD4- CD8- doublenegative T lymphocytes with a distinct TCR repertoire. J Leukoc Biol (2008) 84(6):1400-9. doi:10.1189/jlb.0907651

242. Lee SA, Noel S, Sadasivam M, Hamad ARA, Rabb H. Role of immune cells in acute kidney injury and repair. Nephron (2017) 137(4):282-6. doi:10.1159/000477181

243. Frost EL, Kersh AE, Evavold BD, Lukacher AE. Cutting edge: resident memory CD8 T cells express high-affinity TCRs. J Immunol (2015) 195(8):3520-4. doi:10.4049/jimmunol.1501521

244. Ma C, Mishra S, Demel EL, Liu Y, Zhang N. TGF-beta controls the formation of kidney-resident $\mathrm{T}$ cells via promoting effector $\mathrm{T}$ cell extravasation. J Immunol (2017) 198(2):749-56. doi:10.4049/jimmunol.1601500

245. Nolz JC, Harty JT. IL-15 regulates memory CD8+ T cell O-glycan synthesis and affects trafficking. J Clin Invest (2014) 124(3):1013-26. doi:10.1172/ JCI72039

246. Han SJ, Glatman Zaretsky A, Andrade-Oliveira V, Collins N, Dzutsev A, Shaik J, et al. White adipose tissue is a reservoir for memory $\mathrm{T}$ cells and promotes protective memory responses to infection. Immunity (2017) 47(6):1154-68.e6. doi:10.1016/j.immuni.2017.11.009

247. Wang ZQ, Milne K, Derocher H, Webb JR, Nelson BH, Watson PH. CD103 and intratumoral immune response in breast cancer. Clin Cancer Res (2016) 22(24):6290-7. doi:10.1158/1078-0432.CCR-16-0732

248. Murray T, Fuertes Marraco SA, Baumgaertner P, Bordry N, Cagnon L, Donda A, et al. Very late antigen-1 marks functional tumor-resident CD8 T cells and correlates with survival of melanoma patients. Front Immunol (2016) 7:573. doi:10.3389/fimmu.2016.00573

249. Ganesan AP, Clarke J, Wood O, Garrido-Martin EM, Chee SJ, Mellows T, et al. Tissue-resident memory features are linked to the magnitude of cytotoxic T cell responses in human lung cancer. Nat Immunol (2017) 18(8):940-50. doi:10.1038/ni.3775

250. Nizard M, Roussel H, Diniz MO, Karaki S, Tran T, Voron T, et al. Induction of resident memory $\mathrm{T}$ cells enhances the efficacy of cancer vaccine. Nat Commun (2017) 8:15221. doi:10.1038/ncomms15221

251. Boutet M, Gauthier L, Leclerc M, Gros G, de Montpreville V, Theret N, et al. TGFbeta signaling intersects with CD103 integrin signaling to promote T-lymphocyte accumulation and antitumor activity in the lung tumor microenvironment. Cancer Res (2016) 76(7):1757-69. doi:10.1158/00085472.CAN-15-1545

252. Webb JR, Milne K, Watson P, Deleeuw RJ, Nelson BH. Tumor-infiltrating lymphocytes expressing the tissue resident memory marker $\mathrm{CD} 103$ are associated with increased survival in high-grade serous ovarian cancer. Clin Cancer Res (2014) 20(2):434-44. doi:10.1158/1078-0432.CCR-13-1877

253. Workel HH, Komdeur FL, Wouters MC, Plat A, Klip HG, Eggink FA, et al. CD103 defines intraepithelial CD8+ PD1+ tumour-infiltrating lymphocytes of prognostic significance in endometrial adenocarcinoma. Eur J Cancer (2016) 60:1-11. doi:10.1016/j.ejca.2016.02.026

254. Djenidi F, Adam J, Goubar A, Durgeau A, Meurice G, de Montpreville V, et al. CD8+CD103+ tumor-infiltrating lymphocytes are tumor-specific tissue-resident memory $\mathrm{T}$ cells and a prognostic factor for survival in lung cancer patients. J Immunol (2015) 194(7):3475-86. doi:10.4049/jimmunol. 1402711

255. Wang B, Wu S, Zeng H, Liu Z, Dong W, He W, et al. CD103+ tumor infiltrating lymphocytes predict a favorable prognosis in urothelial cell carcinoma of the bladder. J Urol (2015) 194(2):556-62. doi:10.1016/j.juro. 2015.02.2941

256. Koh J, Kim S, Kim MY, Go H, Jeon YK, Chung DH. Prognostic implications of intratumoral CD103+ tumor-infiltrating lymphocytes in pulmonary squamous cell carcinoma. Oncotarget (2017) 8(8):13762-9. doi:10.18632/ oncotarget. 14632

257. Amsen D, Hombrink P, van Lier RAW. Tumor immunity requires border patrol to fight the enemy within. Nat Immunol (2017) 18(8):870-2. doi:10.1038/ ni.3792

258. Gauthier L, Corgnac S, Boutet M, Gros G, Validire P, Bismuth G, et al. Paxillin binding to the cytoplasmic domain of $\mathrm{CD} 103$ promotes cell adhesion and effector functions for $\mathrm{CD} 8(+)$ resident memory T cells in tumors. Cancer Res (2017) 77(24):7072-82. doi:10.1158/0008-5472.CAN-17-1487

259. Le Floc'h A, Jalil A, Franciszkiewicz K, Validire P, Vergnon I, Mami-Chouaib F. Minimal engagement of $\mathrm{CD} 103$ on cytotoxic T lymphocytes with an
E-cadherin-Fc molecule triggers lytic granule polarization via a phospholipase Cgamma-dependent pathway. Cancer Res (2011) 71(2):328-38. doi:10.1158/0008-5472.CAN-10-2457

260. Sun YY, Peng S, Han L, Qiu J, Song L, Tsai Y, et al. Local HPV recombinant vaccinia boost following priming with an HPV DNA vaccine enhances local HPV-specific CD8+ T-cell-mediated tumor control in the genital tract. Clin Cancer Res (2016) 22(3):657-69. doi:10.1158/1078-0432.CCR-15-0234

261. Cuburu N, Graham BS, Buck CB, Kines RC, Pang YY, Day PM, et al. Intravaginal immunization with HPV vectors induces tissue-resident CD8+ T cell responses. J Clin Invest (2012) 122(12):4606-20. doi:10.1172/ JCI63287

262. Decrausaz L, Pythoud C, Domingos-Pereira S, Derre L, Jichlinski P, Nardelli-Haefliger D. Intravaginal live attenuated Salmonella increase local antitumor vaccine-specific CD8(+) T cells. Oncoimmunology (2013) 2(1):e22944. doi:10.4161/onci.22944

263. Sandoval F, Terme M, Nizard M, Badoual C, Bureau MF, Freyburger L, et al. Mucosal imprinting of vaccine-induced CD8(+) T cells is crucial to inhibit the growth of mucosal tumors. Sci Transl Med (2013) 5(172):172ra20. doi:10.1126/scitranslmed.3004888

264. Schenkel JM, Fraser KA, Masopust D. Cutting edge: resident memory CD8 $\mathrm{T}$ cells occupy frontline niches in secondary lymphoid organs. J Immunol (2014) 192(7):2961-4. doi:10.4049/jimmunol.1400003

265. Ugur M, Schulz O, Menon MB, Krueger A, Pabst O. Resident CD4+ T cells accumulate in lymphoid organs after prolonged antigen exposure. Nat Commun (2014) 5:4821. doi:10.1038/ncomms5821

266. Woon HG, Braun A, Li J, Smith C, Edwards J, Sierro F, et al. Compartmentalization of total and virus-specific tissue-resident memory CD8+ T cells in human lymphoid organs. PLoS Pathog (2016) 12(8):e1005799. doi:10.1371/ journal.ppat.1005799

267. Marriott CL, Dutton EE, Tomura M, Withers DR. Retention of Ag-specific memory CD4(+) $\mathrm{T}$ cells in the draining lymph node indicates lymphoid tissue resident memory populations. Eur J Immunol (2017) 47(5):860-71 doi:10.1002/eji.201646681

268. Durand A, Audemard-Verger A, Guichard V, Mattiuz R, Delpoux A, Hamon P, et al. Profiling the lymphoid-resident T cell pool reveals modulation by age and microbiota. Nat Commun (2018) 9(1):68. doi:10.1038/ s41467-017-02458-4

269. Jelley-Gibbs DM, Brown DM, Dibble JP, Haynes L, Eaton SM, Swain SL. Unexpected prolonged presentation of influenza antigens promotes CD4 T cell memory generation. J Exp Med (2005) 202(5):697-706. doi:10.1084/ jem.20050227

270. Jelley-Gibbs DM, Dibble JP, Brown DM, Strutt TM, McKinstry KK, Swain SL. Persistent depots of influenza antigen fail to induce a cytotoxic CD8 T cell response. JImmunol (2007) 178(12):7563-70. doi:10.4049/jimmunol.178. 12.7563

271. Turner DL, Cauley LS, Khanna KM, Lefrancois L. Persistent antigen presentation after acute vesicular stomatitis virus infection. J Virol (2007) 81(4): 2039-46. doi:10.1128/JVI.02167-06

272. Fazilleau N, Eisenbraun MD, Malherbe L, Ebright JN, Pogue-Caley RR, McHeyzer-Williams LJ, et al. Lymphoid reservoirs of antigen-specific memory T helper cells. Nat Immunol (2007) 8(7):753-61. doi:10.1038/ni1472

273. Beura LK, Wijeyesinghe S, Thompson EA, Macchietto MG, Rosato PC, Pierson MJ, et al. T cells in nonlymphoid tissues give rise to lymph-node-resident memory T cells. Immunity (2018) 48(2):327-38.e5. doi:10.1016/j. immuni.2018.01.015

274. Hofmann M, Oschowitzer A, Kurzhals SR, Kruger CC, Pircher H. Thymusresident memory CD8+ T cells mediate local immunity. Eur J Immunol (2013) 43(9):2295-304. doi:10.1002/eji.201343519

275. Chen W, Konkel JE. Development of thymic Foxp3(+) regulatory T cells: TGF-beta matters. Eur J Immunol (2015) 45(4):958-65. doi:10.1002/eji. 201444999

276. Odaka C, Hauri-Hohl M, Takizawa K, Nishikawa Y, Yano M, Matsumoto M, et al. TGF-beta type II receptor expression in thymic epithelial cells inhibits the development of Hassall's corpuscles in mice. Int Immunol (2013) 25 (11):633-42. doi:10.1093/intimm/dxt026

277. Kutlesa S, Wessels JT, Speiser A, Steiert I, Muller CA, Klein G. E-cadherinmediated interactions of thymic epithelial cells with CD103+ thymocytes lead to enhanced thymocyte cell proliferation. J Cell Sci (2002) 115(Pt 23):4505-15. doi:10.1242/jcs.00142 
278. Weinreich MA, Hogquist KA. Thymic emigration: when and how T cells leave home. J Immunol (2008) 181(4):2265-70. doi:10.4049/jimmunol.181. 4.2265

279. Bonasio R, Scimone ML, Schaerli P, Grabie N, Lichtman AH, von Andrian UH. Clonal deletion of thymocytes by circulating dendritic cells homing to the thymus. Nat Immunol (2006) 7(10):1092-100. doi:10.1038/ni1106-1234b

280. Hadeiba H, Lahl K, Edalati A, Oderup C, Habtezion A, Pachynski R, et al. Plasmacytoid dendritic cells transport peripheral antigens to the thymus to promote central tolerance. Immunity (2012) 36(3):438-50. doi:10.1016/j. immuni.2012.01.017

281. Di Rosa F. Two niches in the bone marrow: a hypothesis on life-long T cell memory. Trends Immunol (2016) 37(8):503-12. doi:10.1016/j.it.2016.05.004

282. Mazo IB, Honczarenko M, Leung H, Cavanagh LL, Bonasio R, Weninger W, et al. Bone marrow is a major reservoir and site of recruitment for central memory CD8+ T cells. Immunity (2005) 22(2):259-70. doi:10.1016/j.immuni. 2005.01.008

283. Tokoyoda K, Zehentmeier S, Hegazy AN, Albrecht I, Grun JR, Lohning M, et al. Professional memory CD4+ T lymphocytes preferentially reside and rest in the bone marrow. Immunity (2009) 30(5):721-30. doi:10.1016/j. immuni.2009.03.015

284. Snell LM, Lin GH, Watts TH. IL-15-dependent upregulation of GITR on CD8 memory phenotype $\mathrm{T}$ cells in the bone marrow relative to spleen and lymph node suggests the bone marrow as a site of superior bioavailability of IL-15. J Immunol (2012) 188(12):5915-23. doi:10.4049/ jimmunol.1103270

285. Zhang X, Dong H, Lin W, Voss S, Hinkley L, Westergren M, et al. Human bone marrow: a reservoir for "enhanced effector memory" CD8+ T cells with potent recall function. J Immunol (2006) 177(10):6730-7. doi:10.4049/ jimmunol.177.10.6730

286. Yamazaki S, Ema H, Karlsson G, Yamaguchi T, Miyoshi H, Shioda S, et al. Nonmyelinating Schwann cells maintain hematopoietic stem cell hibernation in the bone marrow niche. Cell (2011) 147(5):1146-58. doi:10.1016/j. cell.2011.09.053

287. Chaix J, Nish SA, Lin WH, Rothman NJ, Ding L, Wherry EJ, et al. Cutting edge: CXCR4 is critical for CD8+ memory T cell homeostatic self-renewal but not rechallenge self-renewal. J Immunol (2014) 193(3):1013-6. doi:10.4049/ jimmunol.1400488
288. Mortier E, Advincula R, Kim L, Chmura S, Barrera J, Reizis B, et al. Macrophage- and dendritic-cell-derived interleukin-15 receptor alpha supports homeostasis of distinct CD8+ T cell subsets. Immunity (2009) 31(5):811-22. doi:10.1016/j.immuni.2009.09.017

289. Sercan Alp O, Durlanik S, Schulz D, McGrath M, Grun JR, Bardua M, et al. Memory CD8(+) T cells colocalize with IL-7(+) stromal cells in bone marrow and rest in terms of proliferation and transcription. Eur J Immunol (2015) 45(4):975-87. doi:10.1002/eji.201445295

290. Di Rosa F, Gebhardt T. Bone marrow T cells and the integrated functions of recirculating and tissue-resident memory T cells. Front Immunol (2016) 7:51. doi:10.3389/fimmu.2016.00051

291. Quinci AC, Vitale S, Parretta E, Soriani A, Iannitto ML, Cippitelli M, et al. IL-15 inhibits IL-7Ralpha expression by memory-phenotype CD8(+) T cells in the bone marrow. Eur J Immunol (2012) 42(5):1129-39. doi:10.1002/ eji.201142019

292. Kumar BV, Ma W, Miron M, Granot T, Guyer RS, Carpenter DJ, et al. Human tissue-resident memory $\mathrm{T}$ cells are defined by core transcriptional and functional signatures in lymphoid and mucosal sites. Cell Rep (2017) 20(12):2921-34. doi:10.1016/j.celrep.2017.08.078

293. Vieira Braga FA, Hertoghs KM, Kragten NA, Doody GM, Barnes NA, Remmerswaal EB, et al. Blimp-1 homolog Hobit identifies effector-type lymphocytes in humans. Eur J Immunol (2015) 45(10):2945-58. doi:10.1002/ eji. 201545650

294. Kumar BV, Connors TJ, Farber DL. Human T cell development, localization, and function throughout life. Immunity (2018) 48(2):202-13. doi:10.1016/j. immuni.2018.01.007

Conflict of Interest Statement: The author declares that the research was conducted in the absence of any commercial or financial relationships that could be construed as a potential conflict of interest.

Copyright (c) 2018 Takamura. This is an open-access article distributed under the terms of the Creative Commons Attribution License (CC BY). The use, distribution or reproduction in other forums is permitted, provided the original author $(s)$ and the copyright owner are credited and that the original publication in this journal is cited, in accordance with accepted academic practice. No use, distribution or reproduction is permitted which does not comply with these terms. 